SUPLEMENTO/SUPPLEMENT

ESTIMATIVAS POPULACIONAIS 


\title{
ESTADO DE SÃO PAULO, BRASIL, 1970 A 1975 ESTIMATIVAS POPULACIONAIS
}

Edmur Flávio Pastorelo *

Sabina Léa Daviđson Gotlieb*

\begin{abstract}
RSPU-B/314
Pastorelo, E. F. \& Gotlieb, S. L. D. - Estado de São Paulo, Brasil, 1970 a 1975 - Estimativas populacionais. Rev. Saúde públ., S. Paulo, 10 (Supl. 1): $1-65, \quad 1976$.

RESUMO: São apresentadas estimativas populacionais segundo sexo e grupo etário para microrregiōes homogêneas e Regióes Administrativas do Estado de São Paulo (Brasil), no periodo de 1970 a 1975 (1.0 de julho).
\end{abstract}

UnItermos: Estimativas populacionais, São Paulo (Brasil). População. Estatística demógrafo-sanitária.

\section{N TRODUCAO}

Dado o fato de o Recenseamento Geral, no Brasil, se processar decenalmente e em face à necessidade da existência de informaçōes fidedignas e oportunas para uso em estatísticas demógrafo-sanitárias, estimativas populacionais são elaboradas pelas várias entidades ligadas à área de saúde, baseadas em diferentes necessidades e calculadas com critérios, os mais diversos. Como resultado, há perda de comparabilidade dos indicadores de níveis de saúde, devido à inexistência de estimativas populacionais baseadas em metodologia uniforme. São recomendaçōes recentes do Subgrupo-Informação, dos "Grupos de Estudo das Áreas Críticas da Secretaria de Estado da Saúde" 5 e do "Seminário de Situação de Saúde das Áreas Metropolitanas Brasileiras" "que a tarefa da elaboração e apresentação dessas estimativas esteja a cargo de órgãos oficiais como o Departamento de Estatística da Secretaria de Economia e Planejamento do Estado de São Paulo (DEE), a nível estadual, e Instituto Brasileiro de Geografia e Estatística (IBGE), a nível nacional. Entretanto, até o momento, esses órgãos não apresentaram estimativas populacionais detalhadas, para os anos intercensitários.

A finalidade deste trabalho é apresentar estimativas populacionais segundo sexo e grupo etário, para o Estado de São Paulo, de 1970 a 1975 (1. ${ }^{\circ}$ de julho), minimizando, assim, os esforços de todos os profissionais que delas vierem a necessitar.

* Do Departamento de Epidemiologia da Faculdade de Saúde Pública da USP - Avenida Dr. Arnaldo, 715 - São Paulo, SP - Brasil. 
PASTORELO, E. F. \& GOTILIEB, S. I. D. - Estado de São Paulo, Brasil, 1970 a 1975 Estimativas populacionais. Rev. Saúde publ,. S. Paulo, 10(Supl. 1):1-65, 1976

\section{METODOLOGIA}

O nível de detalhamento das estimativas populacionais é o de microrregiões homogêneas, segundo critério apresentado no VIII Recenseamento Geral de $1970^{3}$.

As estimativas populacionais dos municípios, não detalhadas por sexo e idade. para $1 .^{\circ}$ de julho de 1971 a 1975 , foram retiradas das listagens oficiais fornecidas pelo DEE e reunidas de forma a se obterem as populações das microrregiōes homogêneas do Estado.

Para melhor ajuste da tendência temporal dos dados, as populações gerais das microrregiōes em $1 .^{\circ}$ de julho de 1970 foram estimadas por retroprojeção geométrica ${ }^{1}$, utilizando-se as populações de $1 .^{\circ}$ de julho de 1971 e 1972.

A partir dos dados do VIII Recenseamento Geral de $1970^{\circ}$, foi calculada a composição percentual das populações. das microrregióes homogêneas, por sexo e grupo etário; pressupondo que esta composição tenha se mantido constante até 1975, aplicou-se a mesma às populações totais das microrregiōes nos diversos anos. obtendo-se a distribuição etária e por sexo das populações em estudo.

Esta divisão em microrregiōes homogêneas foi comparada à Divisão Administrativa Regional do Estado de São Paulo (Decreto n. ${ }^{\circ} 48.162$, de $3 / 3 / 67$, alterado pelo Decreto $\mathrm{n}^{\circ} 52.576$, de $12 / 12 / 70$ ). verificando-se que estas poderiam ser agrupadas de forma tal que comporiam as onze regiōes administrativas.

Para se conhecer a população de cada uma das onze regióes administrativas do Estado, segundo sexo e idade, no periodo estudado, foram agrupados os contingentes populacionais das microrregiōes homogêneas pertinentes à cada região. Ressalva teve que ser feita. entretanto, quanto à localização dos municípios de Lbirajara - Nova Luzitânia. Com referência à Ubirajara, é município que pertence à microrreyião homogênea da Alta Paulis- ta que, juntamente com outras microrregiões, veio a formar a 11 . $^{2}$ Região Administrativa. Este município, entretanto, pela divisão regional, não pertence à 11. . mas sim, à $70^{\mathrm{a}}$ Região. No cálculo da população total das Regiōes, o número de habitantes de Libirajara foi, portanto, excluído da $11 .^{a}$ Região e anexado à 7. Região.

O mesmo procedimento foi adotado relativamente à Nova Luzitânia. Este município pertence à microrregião homogênea Médio São José dos Dourados que. juntamente com outras, veio a compor a 9. Região Administrativa do Estado. Pelo Decreto citado, todavia, Nova Luzitânia não pertence a esta Região e sim à $8 .^{2}$, portanto, em cuja população total está incluída. Conseqüentemente, essas correções foram efetuadas de modo que as populações dos dois municípios citados fizessem parte das populaçôes das Regiões a que realmente pertencem.

São as seguintes as regiōes administrativas, as microrregiões homogêneas e of municípios que as compöem:

RELACAO DAS REGIOES ADMINISTRATIVAS, MICRORREGIOES HOMOGENEAS DO ESTADO DE SAO PAULO. COM INDICAÇA DOS MUNICAPIOS QUE AS COMPOEM :

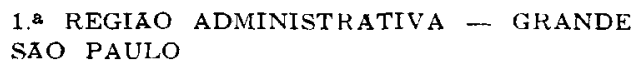

Arujá

Barueri

Biritiba-Mirim

Caieiras

Cajamar

Carapicuiba

Cotia

Diadema

Embu

Embu-Guaçu

Ferraz de Vasconcelos 


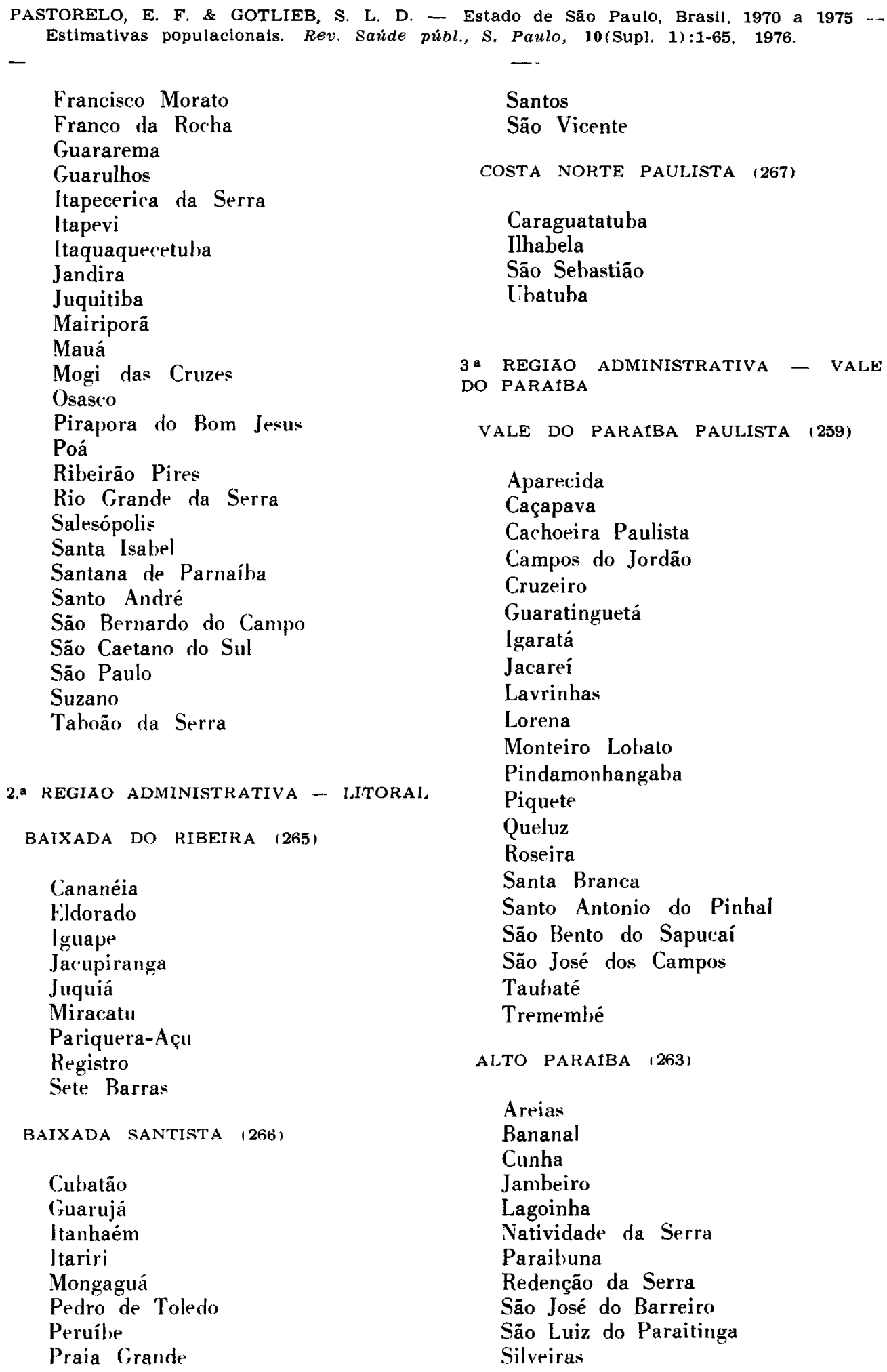

Francisco Morato

Franco da Rocha

Guararema

Guarulhos

Itapecerica da Serra

Itapevi

Itaquaquecetula

Jandira

Juquitiba

Mairiporã

Mauá

Mogi das Cruzes

Osasco

Pirapora do Bom Jesus

Poá

Ribeirão Pires

Rio Grande da Serra

Salesópolis

Santa Isabel

Santana de Parnaiba

Santo André

São Bernardo do Campo

São Caetano do Sul

São Paulo

Suzano

Tahoão da Serra

Areias

Bananal

Cunha

Jambeiro

Lagoinha

Natividade da Serra

Paraibuna

Redenção da Serra

São José do Barreiro

São Luiz do Paraitinga

Silveiras 
PASTORElo, E. F. \& GOTLIEB, S. L. D. - Estado de São Paulo, Brasil, 1970 a 1975 Estimativas populacionais. Rev. Saúde públ., S. Paulo, 10(Supl. 1):1-65. 1976

4 a REGIXO ADMINISTRATIVA - SOROCABA

SERRA DE BOTUCATU (253)

Anhembi

Arandu

Areiópolis

Avaré

Bofete

Botucatu

Cerqueira César

Conchas

Coronel Macedo

Itaí

Itatinga

Paranapanema

Pardinho

Santa Bárbara do Rio Pardo

São Manuel

Taquarituba

TATUî (255)

Boituva

Cerquilho

Cesário Lange

Laranjal Paulista

Pereiras

Porangaba

Tatuí

Tietê

SOROCABA (256)

Araçoiaba da Serra

Cabreúva

Capela do Alto

Iperó

Itu

Mairinque

Porto Feliz

Salto

Salto de Pirapora

São Roque

Sarapuí

Sorocaba

Votorantim

CAMPOS DE ITAPETININGA (260)

Angatuba

Barão de Antonina
Buri

Guareí

Itaberá

Itapetininga

Itapeva

Itaporanga

Itararé

Ribeirão Vermelho do Sul

PARANAPIACABA (261)

Capão Bonito

Guapiara

Ibiúna

Piedade

Pilar do Sul

Ribeirão Branco

São Miguel Arcanjo

Tapiraí

APIAÍ (264)

Apiaí

Barra do Turvo

Iporanga

Ribeira

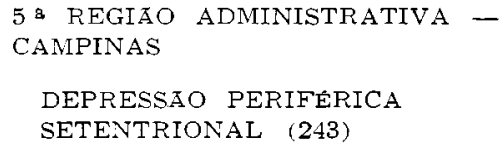

Aguaí

Casa Branca

Leme

Mogi-Guaçu

Mogi-Mirim

Pirassununga

Porto Ferreira

Santa Cruz da Conceição

Santa Cruz das Palmeiras

Tambaú

ENCOSTA OCIDENTAL DA

MANTIQUEIRA PAULISTA (244)

Águas da Prata

Caconde

Divinolândia

Itobi

Mococa

Pinhal 
PAstorelo, E. F. \& GOTLIEB, S. L. D. - Estado de São Paulo, Brasil, 1970 a 1975 Estimativas populacionais. Rev. Saúde públ., S. Paulo, 10(Supl. 1):1-65, 1976.

Santo Antonio do Jardim

São João da Boa Vista

São José do Rio Pardo

São Sebastião da Grama

Tapiratiba

Vargem Grande do Sul

RIO CLARO (247)

Águas de São Pedro

Analândia

Brotas

Corumbataí

Ipeúna

Itirapina

Rio Claro

Santa Maria da Serra

São Pedro

Torrinha

CAMPINAS (248)

Americana

Araras

Artur Nogueira

Campinas

Conchal

Cordeirópolis

Cosmópolis

Elias Fausto

Indaiatuba

Jaguariúna

Limeira

Monte Mor

Nova Odessa

Paulínia

Santo Antonio de Posse

Sumaré

Valinhos

Vinhedo

ESTANCIAS HIDROMINERAIS

PAULISTAS (249)

Águas de Lindóia

Amparo

Itapira

Lindóia

Monte Alegre do Sul

Pedreira

Serra Negra

Socorro
ACUCAREIRA DE PIRACICABA (254)

Capivari

Charqueada

Iracemapolis

Mombuca

Piracicaba

Rafard

Rio das Pedras

Santa Bárbara d'Oeste

Santa Gertrudes

JUNDIAf $\quad(257)$

Campo Limpo

ltatiba

Itupeva

Jarinu

Jundiaí

Louveira

Morungaba

Várzea Paulista

BRAGANÇA PAULISTA (258)

Atibaia

Bom Jesus dos Perdóes

Bragança Paulista

Joanópolis

Nazaré Paulista

Pedra Bela

Pinhalzinho

Piracaia

6.9 REGIÃO ADMINISTRATIVA -

RIBEIRAOO PRETO

BARRETOS (228)

Barretos

Colina

Colômbia

Guaíra

Jaborandi

ALTA MOGIANA (229)
Aramina
Buritizal
Guará
Igarapava
Ipuã
Ituverava 


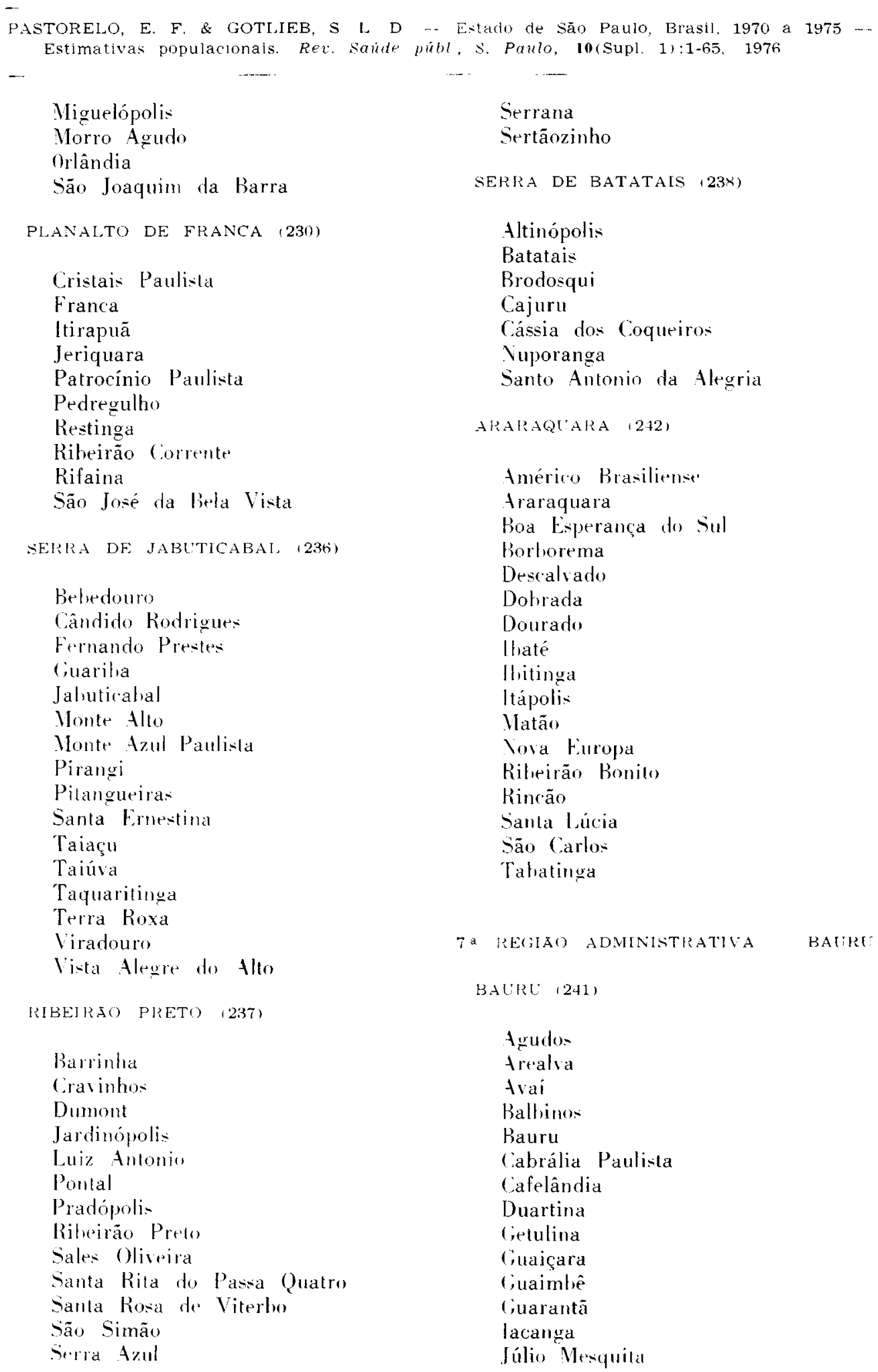

Miguelópolis

Morro Aqudo

Orlàndia

São Joaquim da Barra

PIANALTO DE FRANCA (230)

Cristais Paulisala

Franca

Itirapuã

Jeriquara

Patrocinio Paulista

Pedregulho

Restingat

Ribeirão Corrente

Rifaina

São José da Bela Vista

SElRA DE: JABUTICABAI, $1236 \%$

Beliedouro

Cândido Rodrigues:

Fernando Prestes

Guariha

Jahuticalial

Monte Alto

Monte Azul Paulisua

Pirangi

Pilangueiras

Santa Ernestina

Taiaçu

Taiúva

Taquaritinga

Terra Roxa

Viradouro

Vista flegre do floo

RIBEIRAO PRETO (23T)

Serrana

Sertãozinho

SERRA DE BATATAIS (23x)

Altinópolis

Batatais

Brodosqui

Cajuru

Cássia dos Coqueiros

Vuporanga

Santo Antonio da Alegria

ARARAQLARA 1212,

tmérico Brasilienss'

traraquara

Boa Esperança do Sul

Borborema

Descalvado

Dohrada

Dourado

Ihaté

Ihitinga

Itápolis:

Matão

Vova Europa

Rilieirão Bonilo

Rincão

Santa lúcia

São Carlo:

Tahatinga

Ta REGIAOC ADMINISTRATILA BALRE

BALRL (241)

tyude=

trealia

traí

Balhinom

Rauru

Cabrália Paulista

Cafelândia

Duartina

Getulina

Cuaiçara

Guaimbê

Guarantã

lacanga

Júlio Mesquila 

Estimativas populacionais. Rev. Saúde públ, S. Paulo, 10(Supl, 1):1-65, 1976

Lençóis Paulista

Lins

Iucianópolis

Pirajuí

Piratininga

Pongaí

Presidente Alves

Promissão

Reginópolis

Sahino

Iru

JAŨ 1246)

Bariri

Barra Bonita

Bocaina

Boracéia

Dois Córregos

Igaraçu do Tietê

Itaju

Itapui

Jaú

Macatuba

Mineiros do Tirtê

Pederneiras

ช.a REGIÃO ADMINISTRATIVA - SẢO JOSE DO RIO PRETO

ALTA ARARAQUARENSE DE FERNANDOPOL.IS (225)

Aparecida d'Oeste
Dolcinópolis
Estrela d'Oeste
Fernandópolis
Guarani d'Oeste
Indiaporã
Jales
Macedônia
Marinópolis
Meridiano
Mira Estrela
Palmeira d'Oeste
Paranapuã
Pedranópolis
Populina
Rubinéia
Santa Albertina
Santa Clara d'Oeste

Santa Fé do Sul

Santana da Ponte Pensa

Santa Rita d'Oeste

São Francisco

São João das Duas Pontes

Três Fronteiras

Turmalina

Urânia

ALTA ARARAQUARENSE DE VOTUPORANGA (226)

Álvares Florence

Américo de Campos

Cardoso

Cosmorama

Pontes Gestal

Valentim Gentil

Voluporanga

DIVISOR TURVO-GRANDE (227)

Altair

Guaraci

Icém

Olímpia

Orindiúva

Paulo de Faria

Riolândia

DIVISOR SAO JOSE DOS

DOURADOS-TIETE (233)

Adolfo

José Bonifário

Macaubal

Mendonça

Monções

Monte Aprazivel

Neves Paulista

Nhandeara

Vipoã

Planalto

Poloni

Sehastianópolis do Sul

[ 'nião Paulista

SĀO JOSE DO KIO PRETO (234)

Bady Bassit

Bálsamo

Cedral

Cuapiaçu 
PASTORELo, E. F. \& GOTliEB, S. L. D. - Estado de São Paulo, Brasil, 1970 a 1975 Estimativas populacionais. Rev. Saúde pübl., S. Paulo, 10(Supl. 1):1-65, 1976.

Ibirá

Jaci

Mirassol

Mirassolândia

Nova Aliança

Nova Granada

Onda Verde

Palestina

Potirendaba

São José do Rio Preto

Tanabi

U.choa

MÉdIA ARARAQUARENSE (235)

Ariranha

Cajobi

Catanduva

Catiguá

Irapuã

Itajobi

Novo Horizonte

Palmares Paulista

Paraíso

Pindorama

Sales

Santa Adélia

Severínia

Tabapuã

Urupês 9.a REgiāo AdMinistrativa ARACATUBA

ALTA NOROESTE DE ARAÇATUBA

(231)

Andradina

Araçatuba

Bento de Abreu

Castilho

Guaraçaí

Guararapes

Itapura

Lavínia

Mirandópolis

Muritinga do Sul

Nova Independência

Pereira Barreto

Rubiácea
Sud Menucci

Valparaíso

MÉdIO SAO JOSE DOS DOURADOS (232)

Auriflama

Floreal

Gastão Vidigal

General Salgado

Guzolândia

Magda

Nova Luzitânia *

ALTA NOROESTE DE PENAPOLIS

(240)

Alto Alegre

Avanhandava

Barbosa

Bilac

Birigui

Braúna

Buritama

Clementina

Coroados

Gabriel Monteiro

Glicério

Luisiânia

Penápolis

Piacatu

Santópolis do Aguapei

Turiúba

10.a REGIĀO ADMINISTRATIVA -

PRESIDENTE PRUDENTE

Nova ALTA PAULista (239)

Adamantina

Dracena

Flora Rica

Flórida Paulista

Inúbia Paulista

Irapuru

Junqueirópolis

Lucélia

Mariápolis

Monte Castelo

Nova Guataporanga

Oswaldo Cruz

* Nova Luzitânia pertence à 8. Região Administrativa - São José do Rio Preto. 
PASTORElo, E. F. \& Gotlieb, S. L. D. - Estado de São Paulo, Brasil, 1970 a 1975 Estimativas populacionais. Rer. Saúde públ., S. Paulo, 10(Supl. 1):1-65, 1976.

Ouro Verde

Pacaembu

Panorama

Parapuã

Paulicéia

Rinópolis

Sagres

Salmorão

Santa Mercedes

São João do Pau d'Alho

Tupi Paulista

ALTA SOROCABANA DE

PRESIDENTE PRUDENTE

(250)

Alfredo Marcondes

Álvares Machado

Anhumas

Caiabu

Caiuá

Estrela do Norte

Iepê

Indiana

João Ramalho

Marabá Paulista

Martinópolis

Mirante do Paranapanema

Narandiba

Piquerobi

Pirapozinho

Presidente Bernardes

Presidente Epitácio

Presidente Prudente

Presidente Venceslau

Rancharia

Regente Feijó

Sandovalina

Santo Anastácio

Santo Expedito

Taciba

Tarabaí

Teodoro Sampaio

11. REGIAO ADMINISTRATIVA - MARILIA

ALTA PAULISTA (245)

Álvaro de Carvalho

Alvinlândia

Bastos

Gália
Garça

Herculândia

Iacri

Lupércio

Marília

Ocauçu

Oriente

Pompéia

Queirós

Quintana

Tupã

Ubirajara *

Vera Cruz

ALTA SOROCABANA DE ASSIS (251)

Assis

Borá

Campos Novos Paulista

Cândido Mota

Cruzália

Echaporã

Florinéa

Ibirarema

Lutécia

Maracaí

Oscar Bressane

Palmital

Paraguaçu Paulista

Platina

Quatá

OURINHOS (252)

Bernardino de Campos

Chavantes

Fartura

Ipauçu

Manduri

óleo

Ourinhos

Piraju

Ribeirão do Sul

Salto Grande

Santa Cruz do Rio Pardo

São Pedro do Turvo

Sarutaiá

Taguaí

Tejupá

Timburi

* Ubirajara pertence à 7.\& Regiăo Administrativa - Bauru. 
PAStorelo, E. F. \& GOTLIEB, S. L. D. - Estado de São Paulo, Brasil, 1970 a 1975 Estimativas populacionais. Rev. Saulde públ., S. Paulo, 10(Supl. 1):1-65, 1976

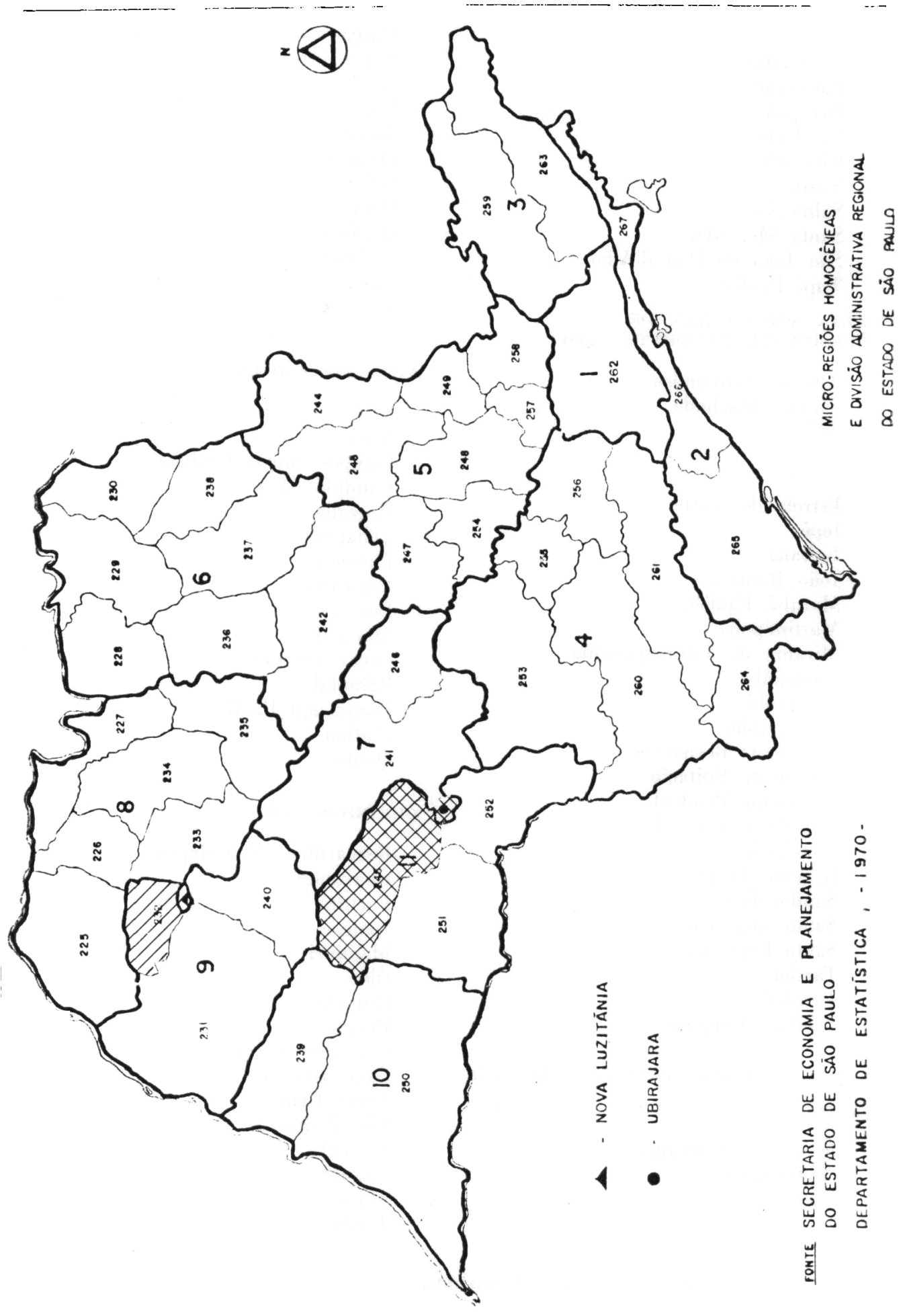


PASTORELO, E. F. \& GOTLIEB, S L D. - Estado de São Paulo, Brasil, 1970 a 1975

Estimativas populacionais. Rev. Saúle publ., S. Paulo, 10(Supl. 1):1-65, 1976

\section{RESULTADOS}

São apresentadas nas Tabelas de 1 a 42. as estimativas populacionais de 42 microrregiôes homogêneas do Estado de São Paulo. em 1..$^{\circ}$ de julho de 1970 a
1975. A microrregião da Grande São Paulo, por constituir-se em uma Regiār Administrativa, está incluida no conjunto de Tabelas 43 a 53 , referentes às estimativas das composiçōes populacionais das Regiōes Administrativas do Estado de São Paulo. em 1. ${ }^{\circ}$ de julho de 1970 a 1975.

RSPU-B/314

Pastorelo, E. F. \& Gotlieb, S. L. D. - [State of S. Paulo, Brazil - 1970-1975

- Population projections]. Rev. Saúde públ., S. Paulo, 10:1-65, 1976.

SUMMARY: Population projections of the State of S. Paulo, Braztl, by sex, age groups and its administrative divisions are presented for the period 1970 to 1975 (1st of July).

UNITERMS: Population projections, S. Paulo State (Brazil). Population.

\section{REFERENCIAS BIBLIOGRAFICAS}

1. BERQUio, E. et al. - Estatística vital. 9. edição. São Paulo, 1972. p. 71-74

2. FUNDAÇAO IBGE - Censo demográfico: São Paulo. Rio de Janeiro, 1973. Tomo 18 , v. 1 . (VIII Recenseamento Geral. 1970)

3. FUNDAÇAO IBGE - Sinopse preliminar do censo demográfico: São Paulo. Rio de Janeiro, 1971. (VIII Recensea. mento Geral. 1970).
4. REGISTRO de dados. In: Seminário sobre a Situação de Saúde nas Areas Metropolitanas Brasileiras, São Paulo. 1975. Faculdade de Saúde Pública da USP, Sāo Paulo, 1975.

5. SÃo PAUlo (Estado). Secretaria da Saúde. Grupo de Estudos das Áreas Críticas. Sug-grupo Informação. Recomendaçōes, São Paulo, 1975

Recebido para publicaçõo em 19/11/1975 A provado para poblicaç̃o em 05/01/1976 


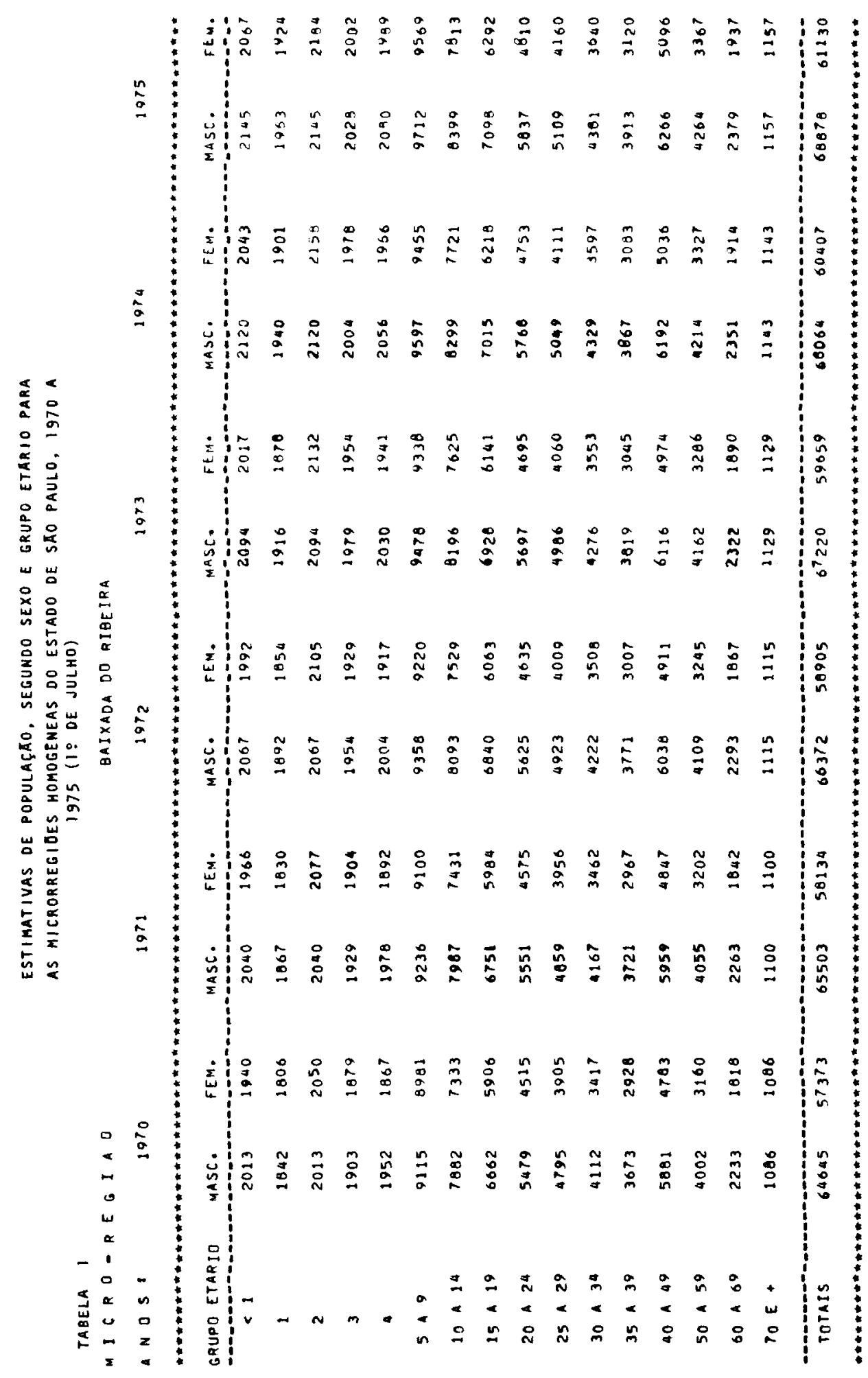




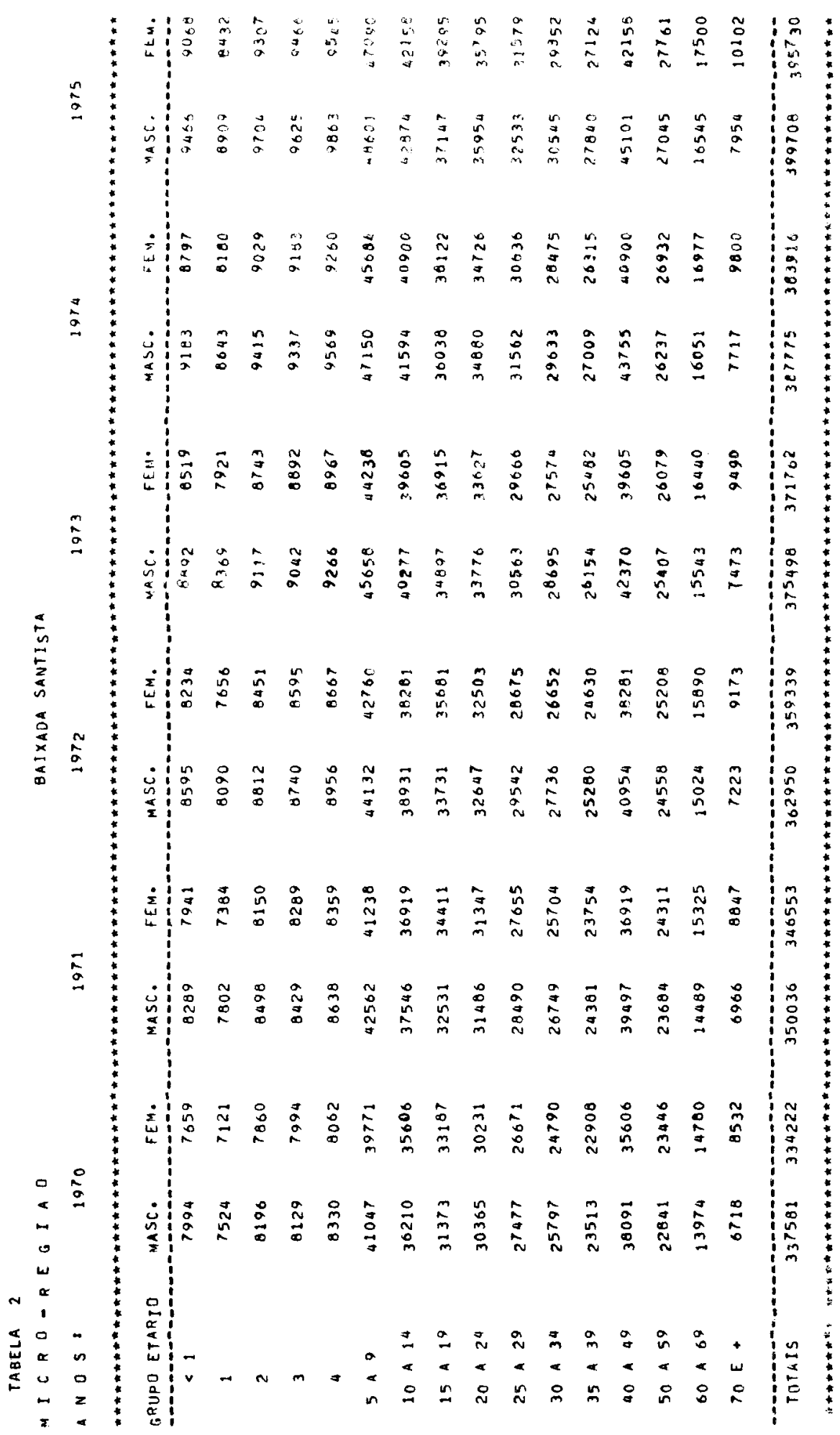




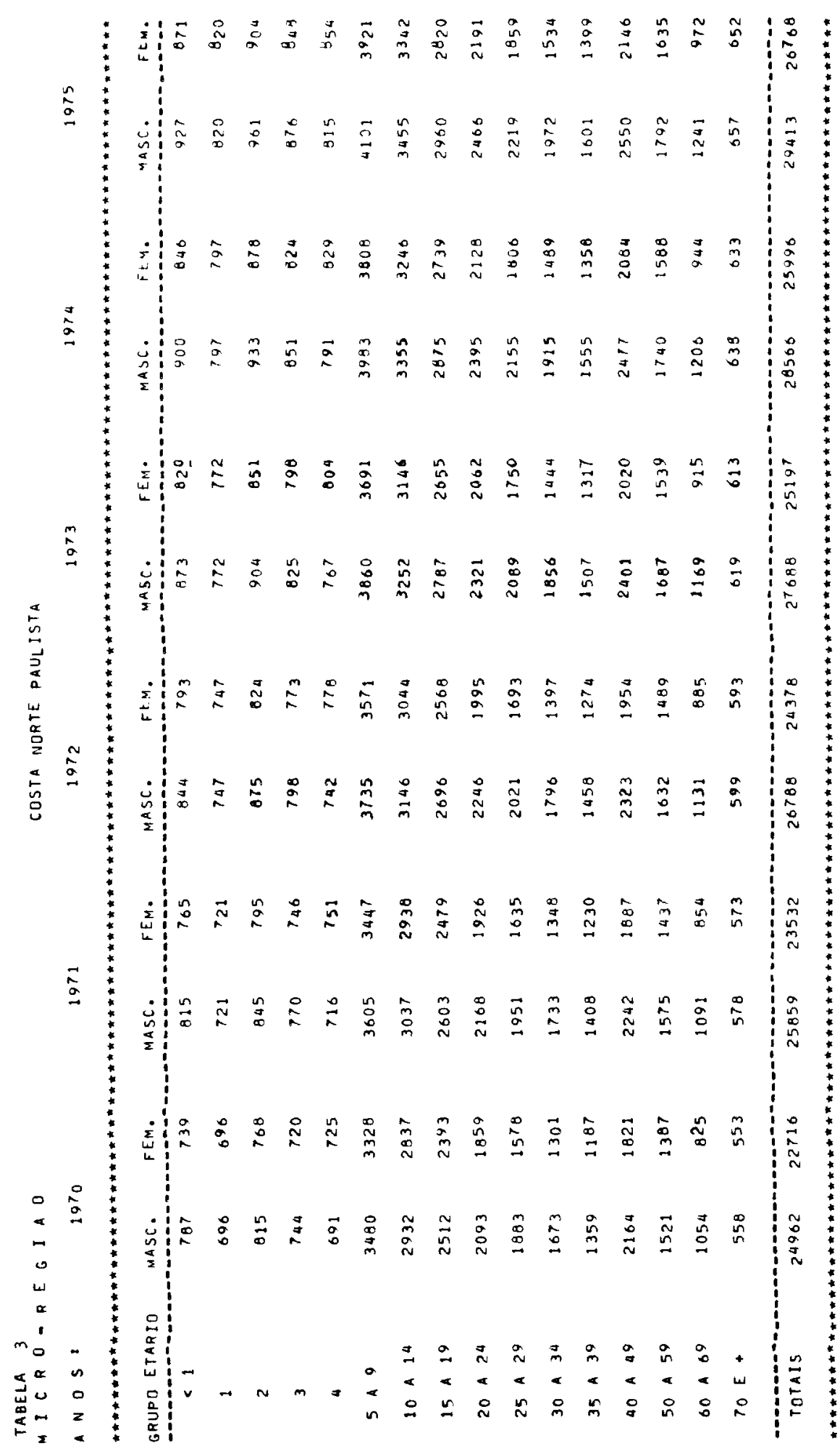




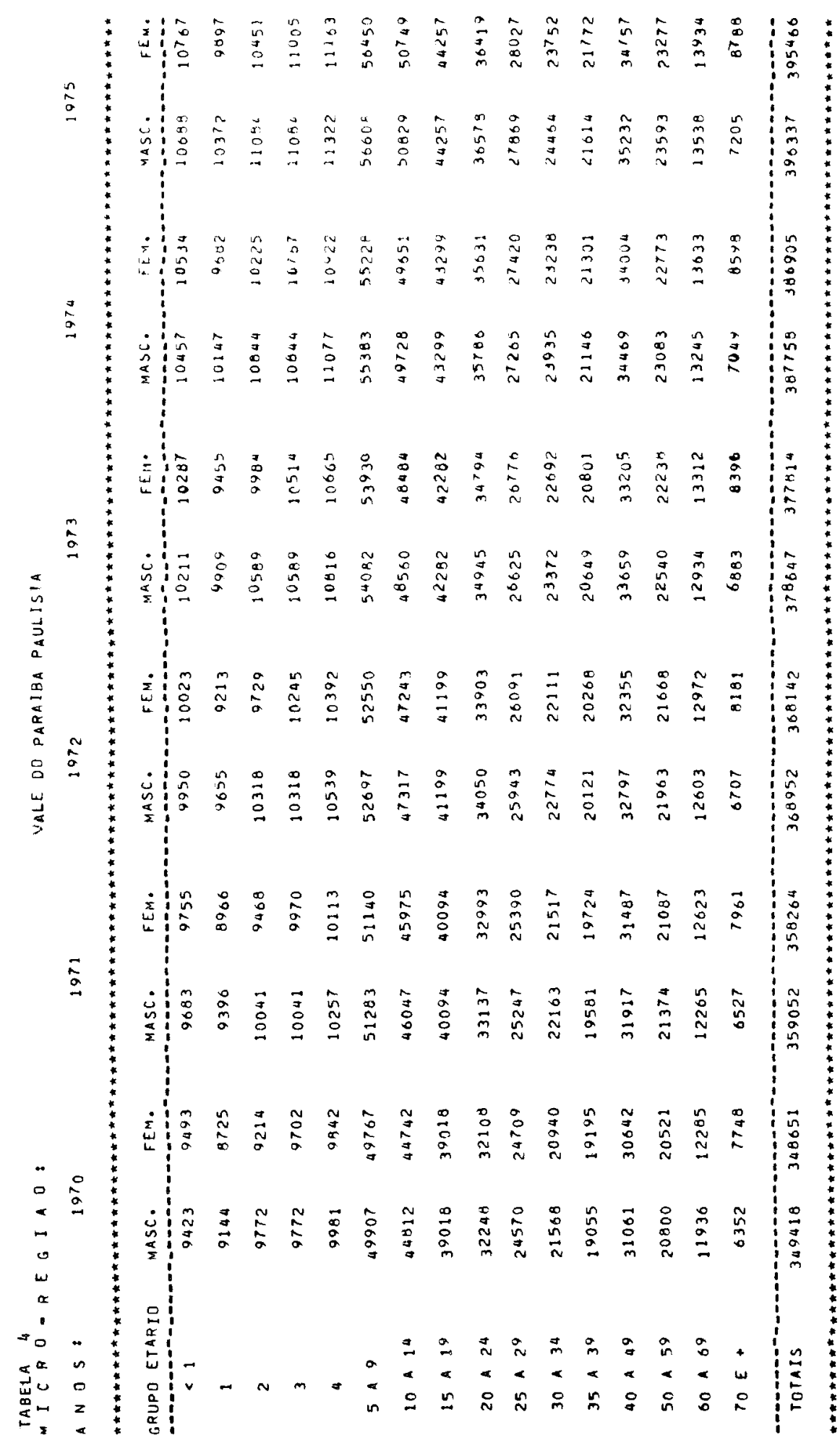




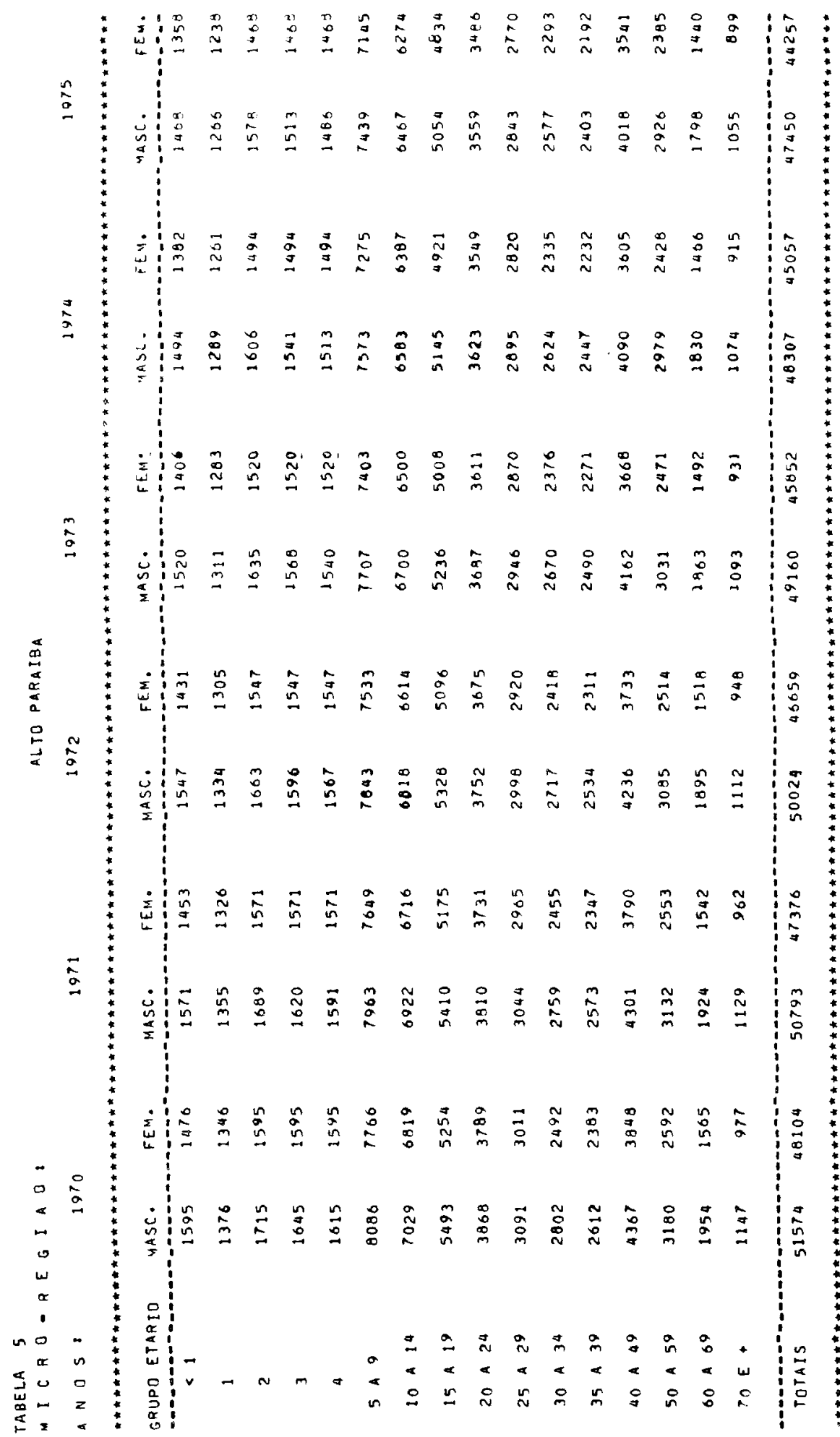




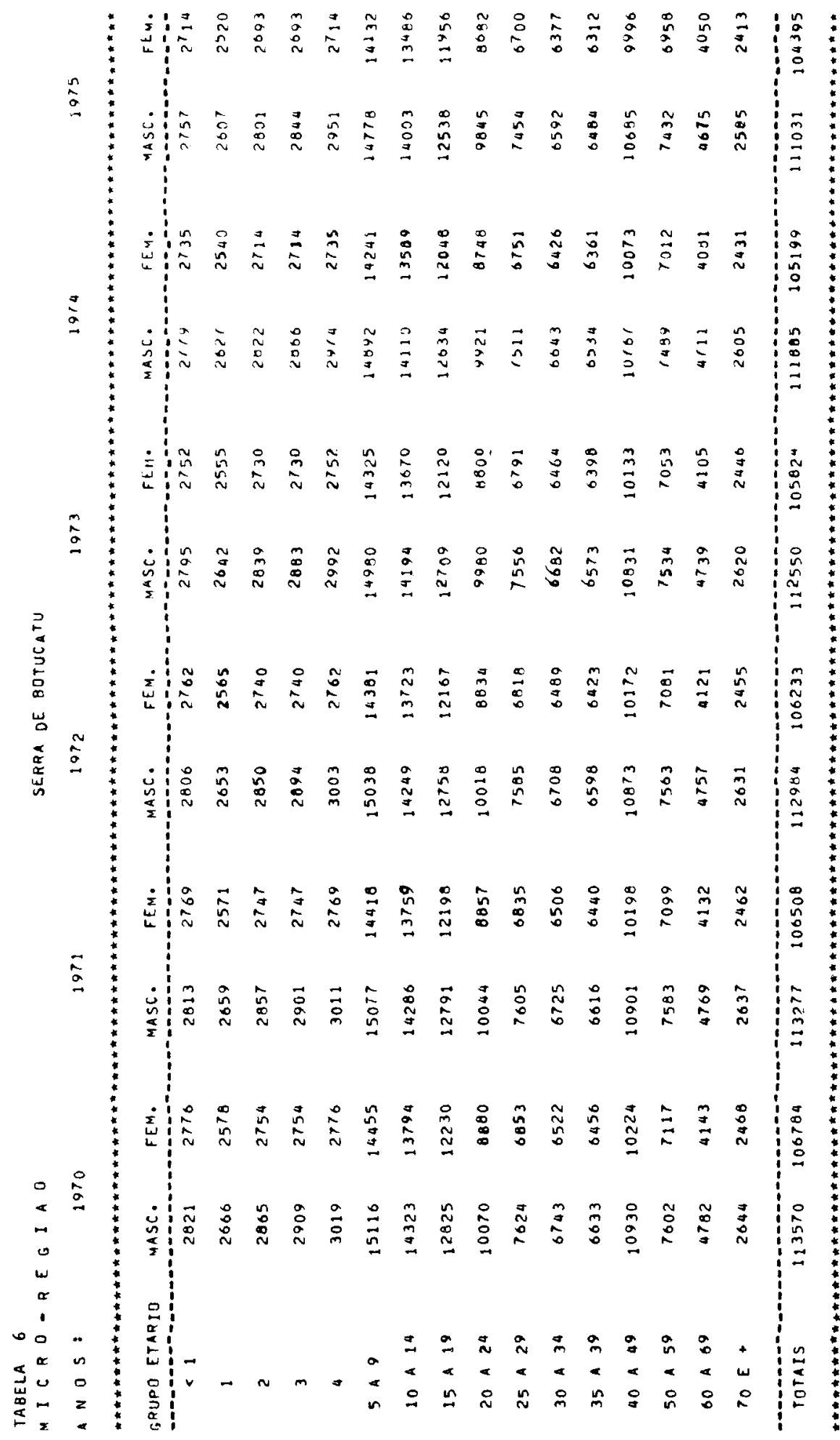




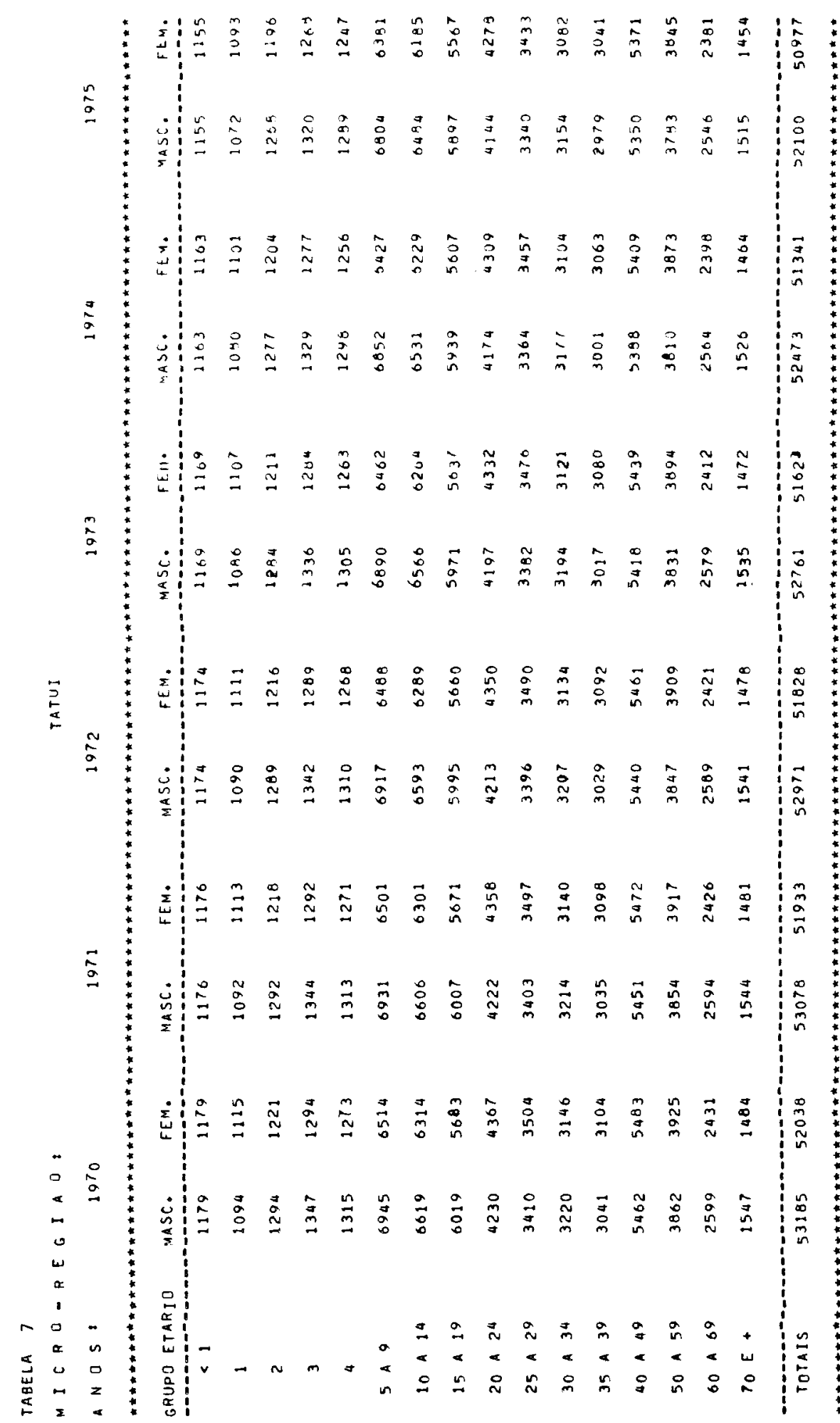




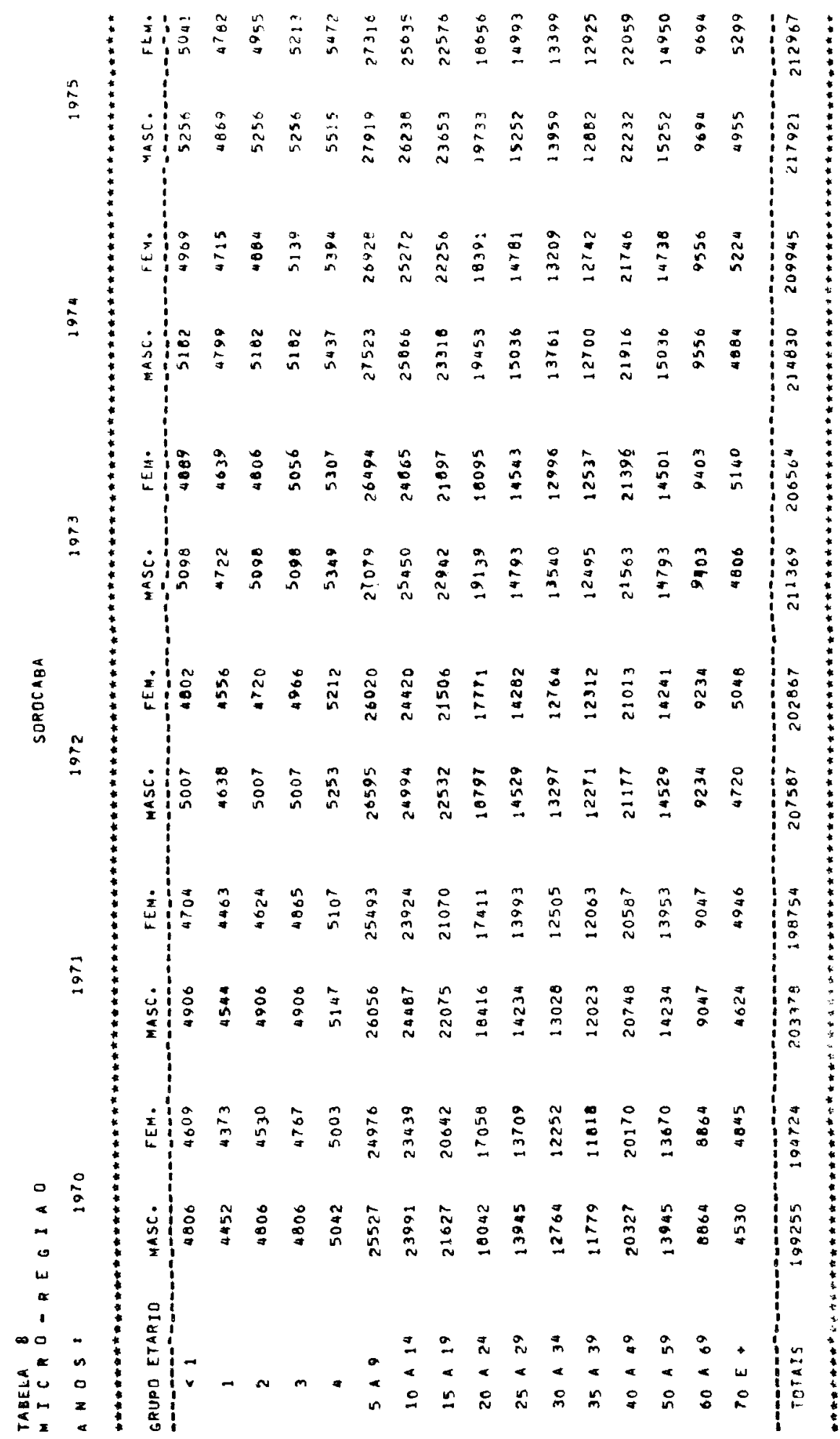




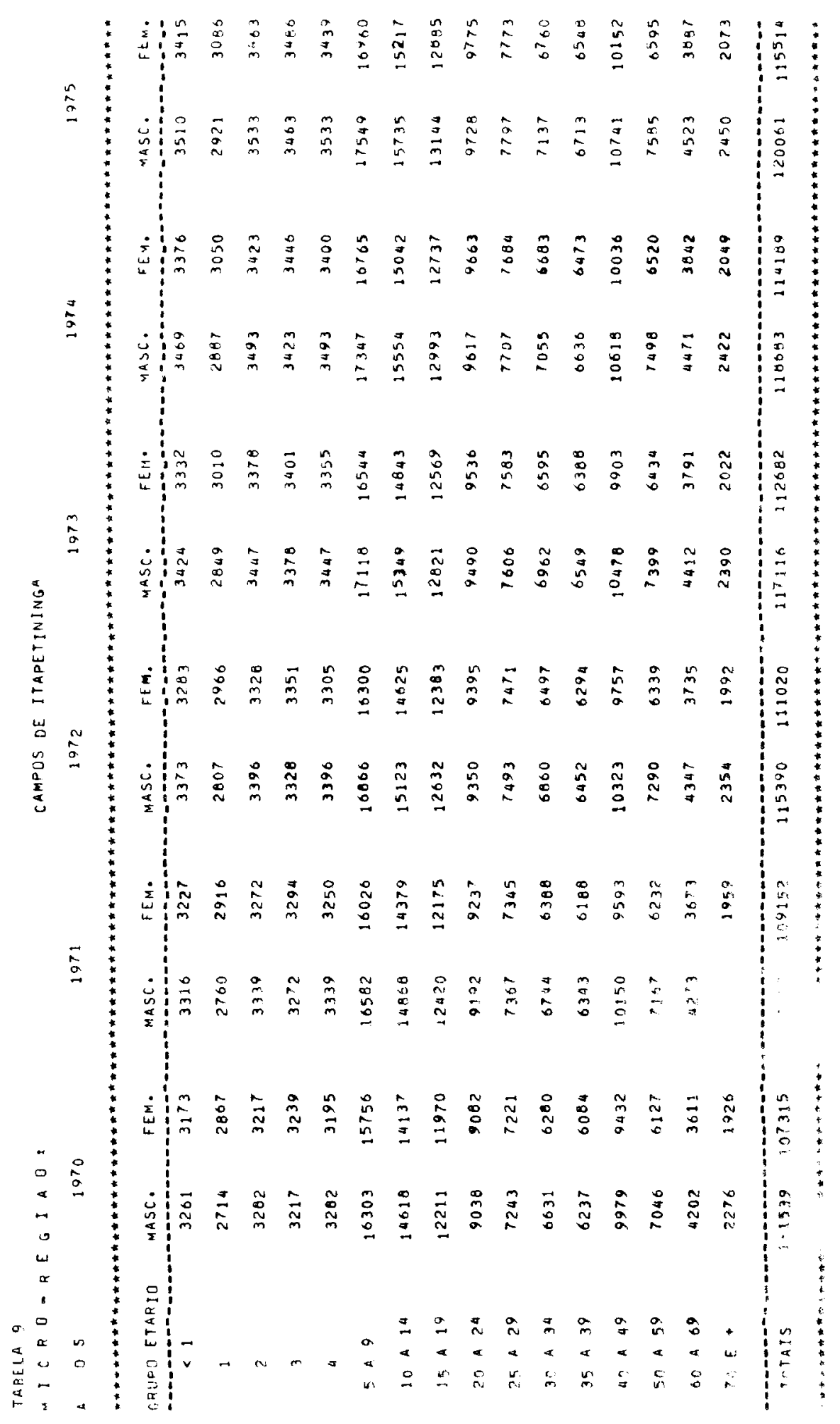




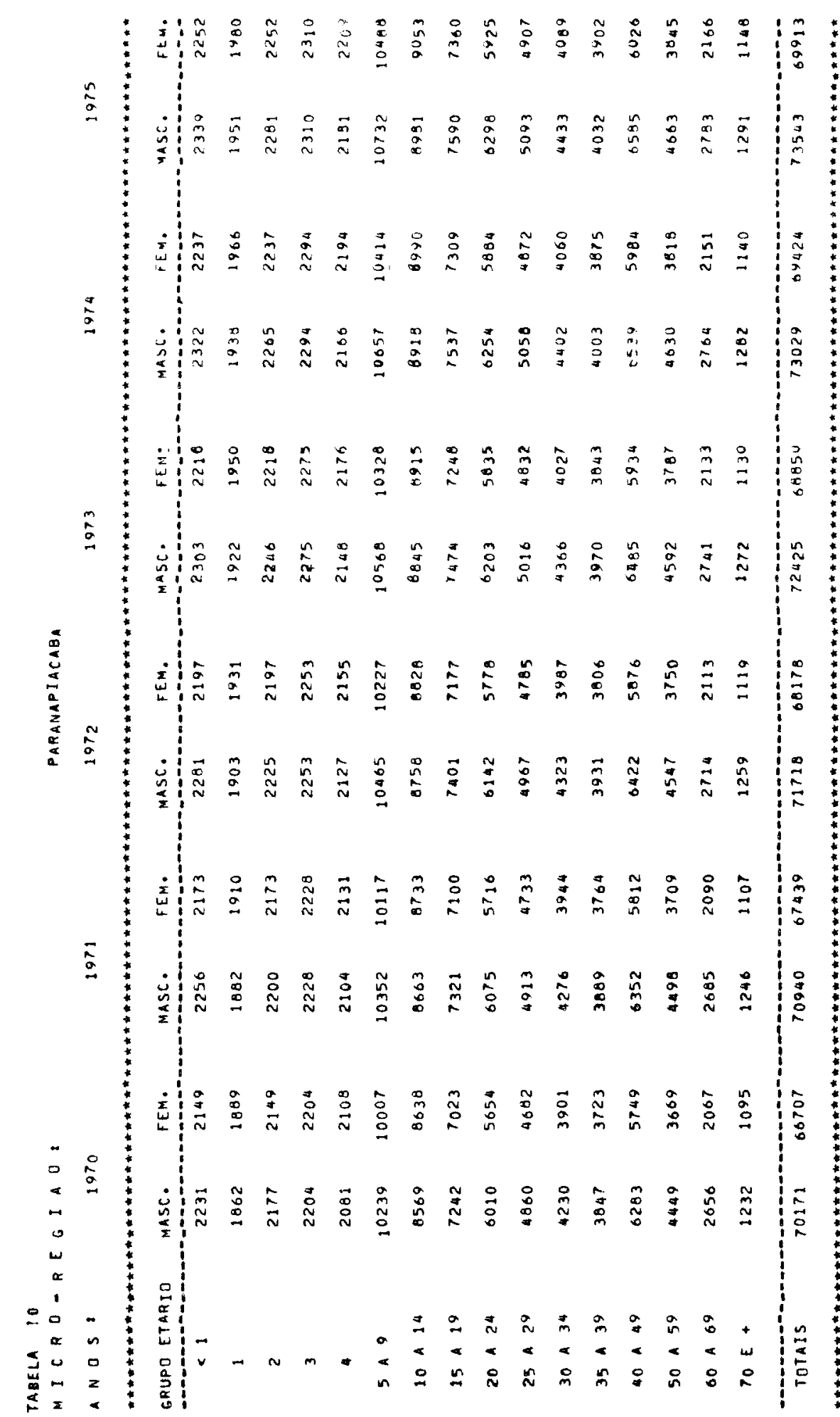




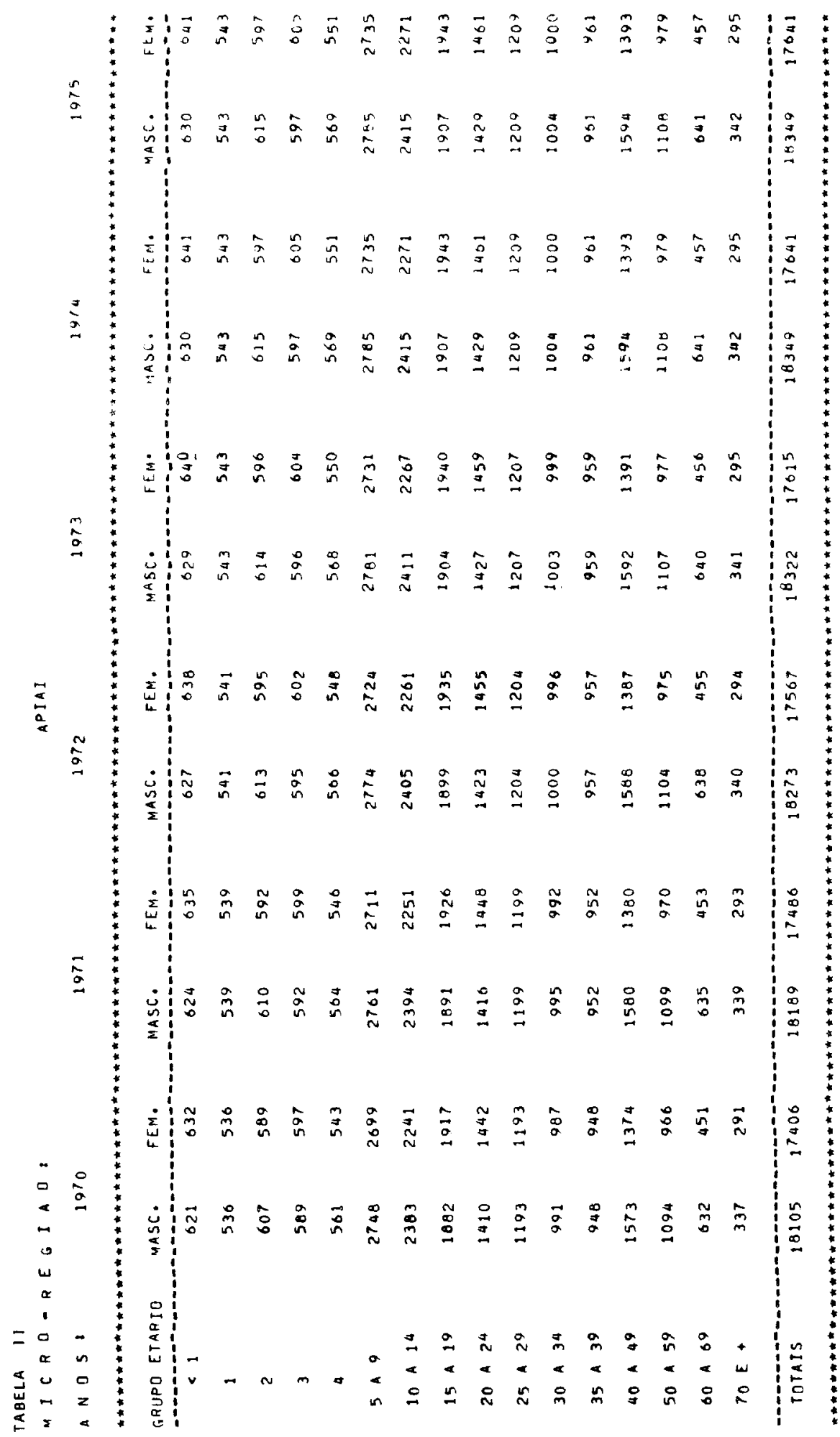




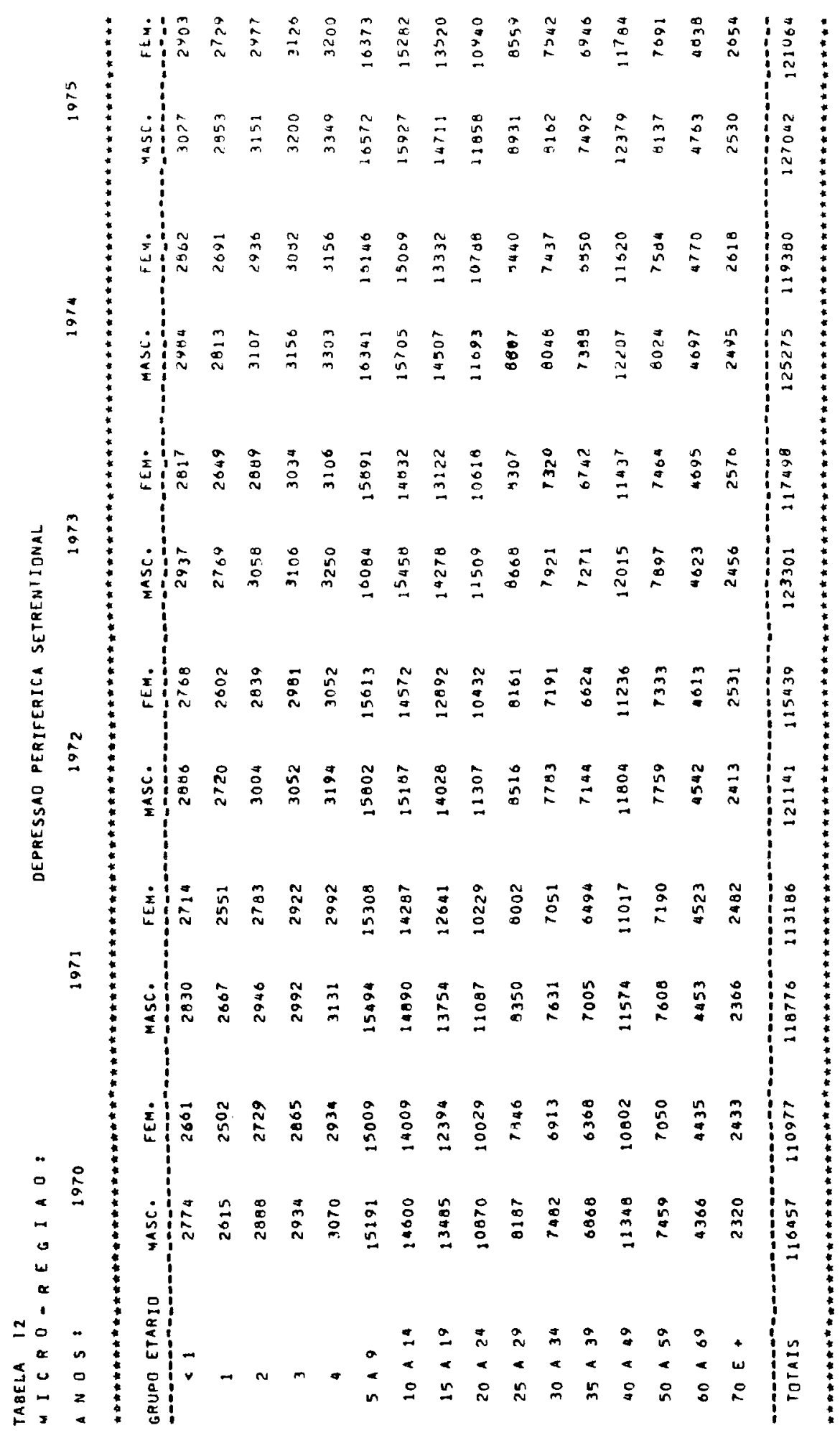




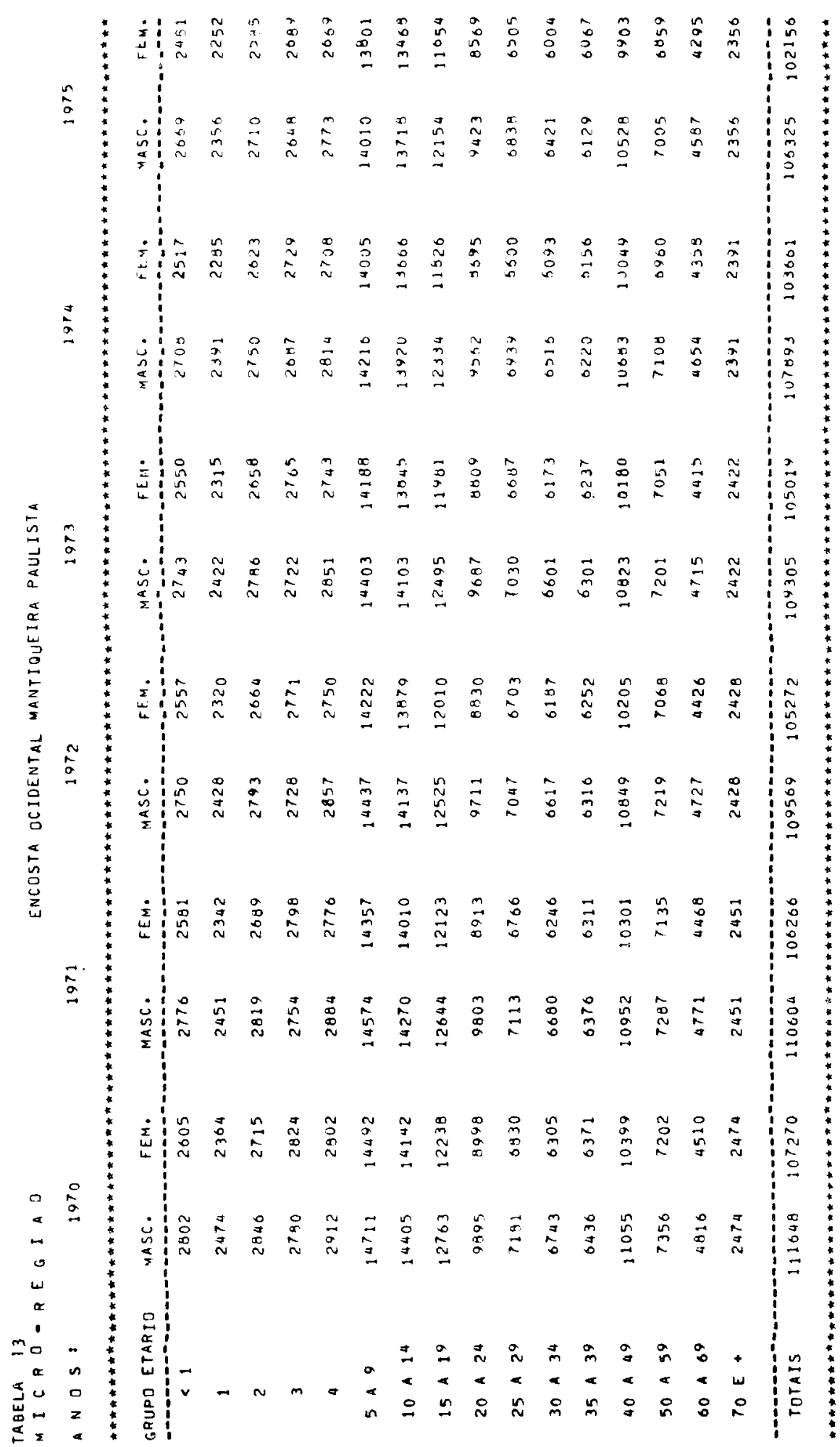




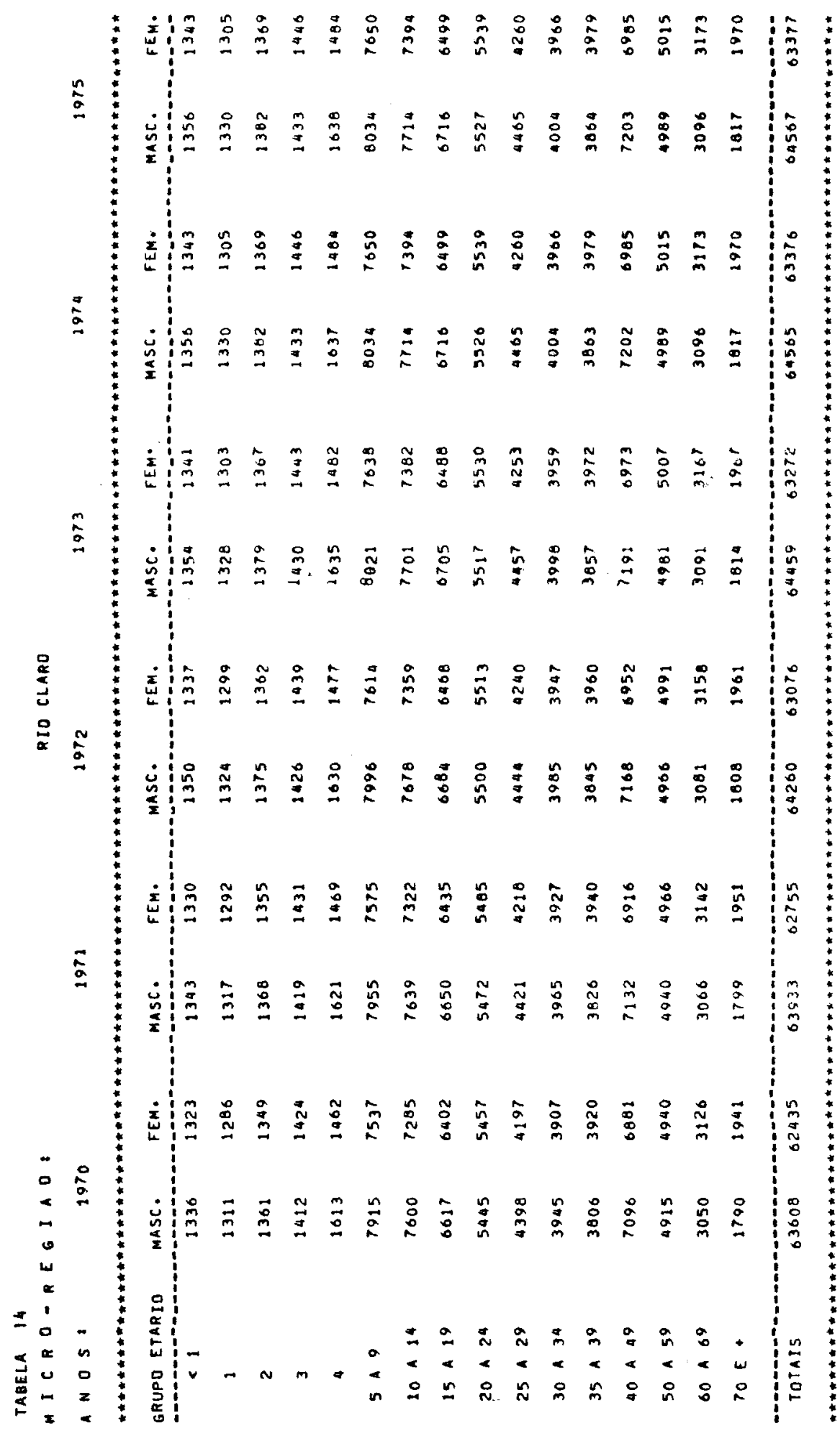




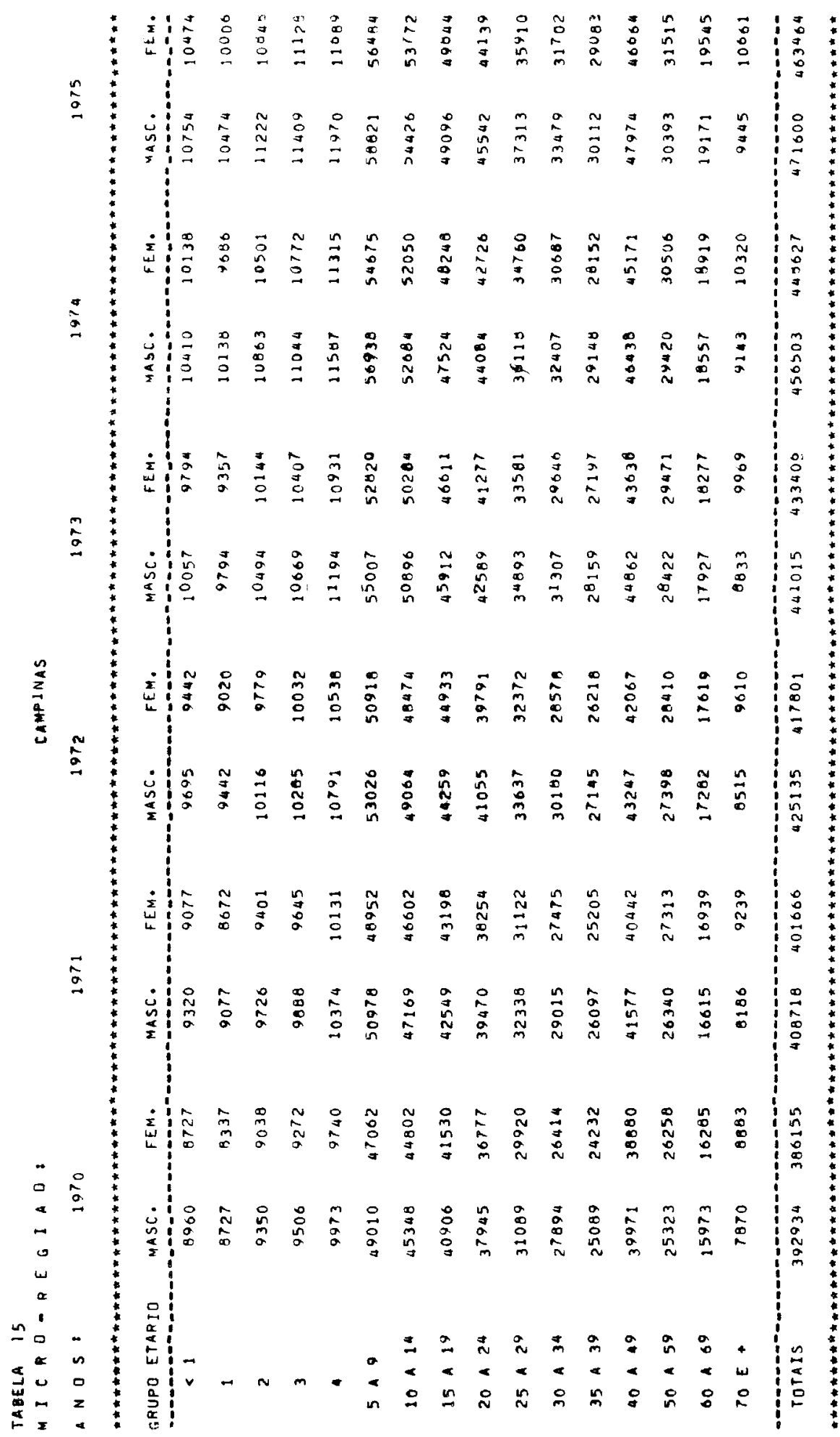




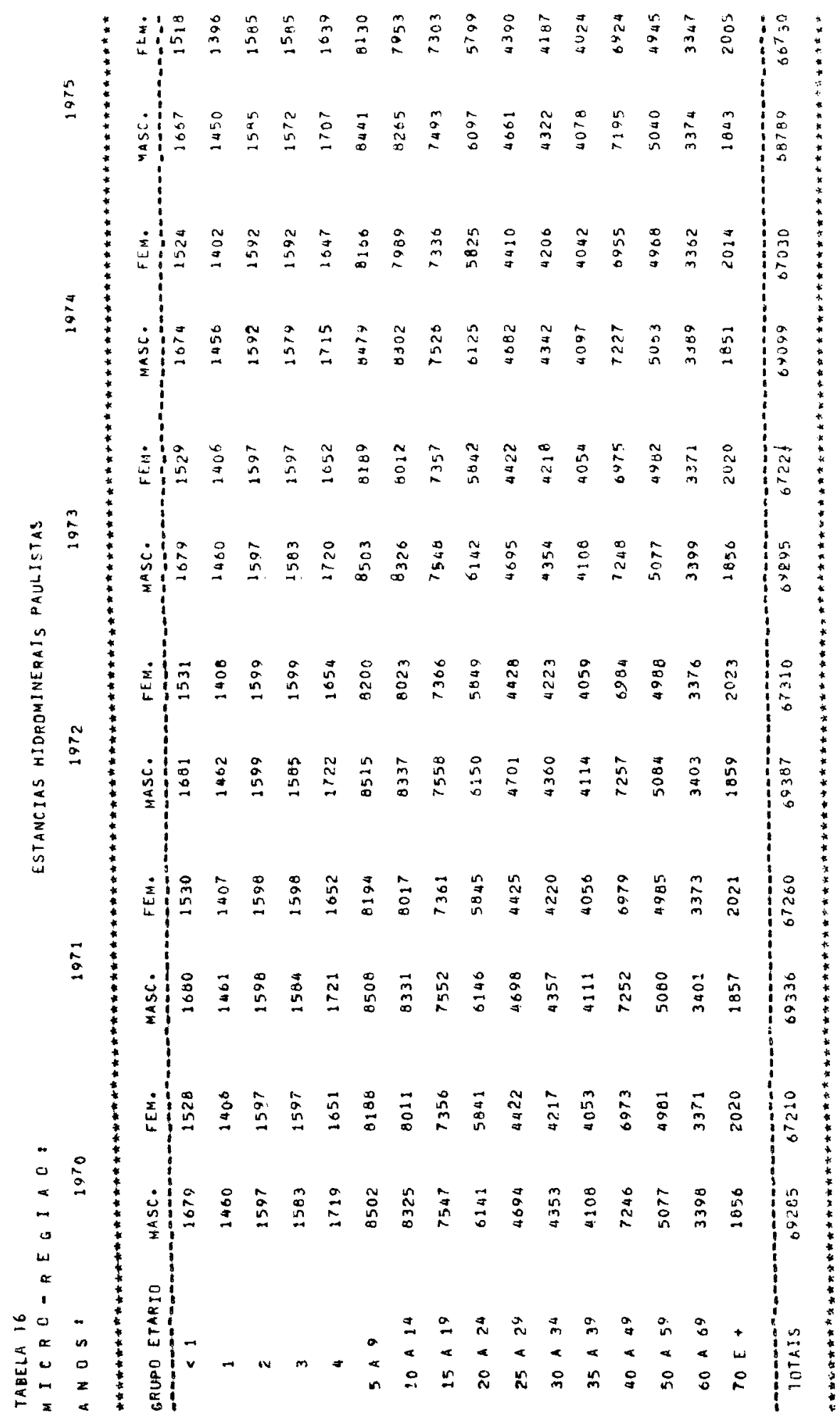




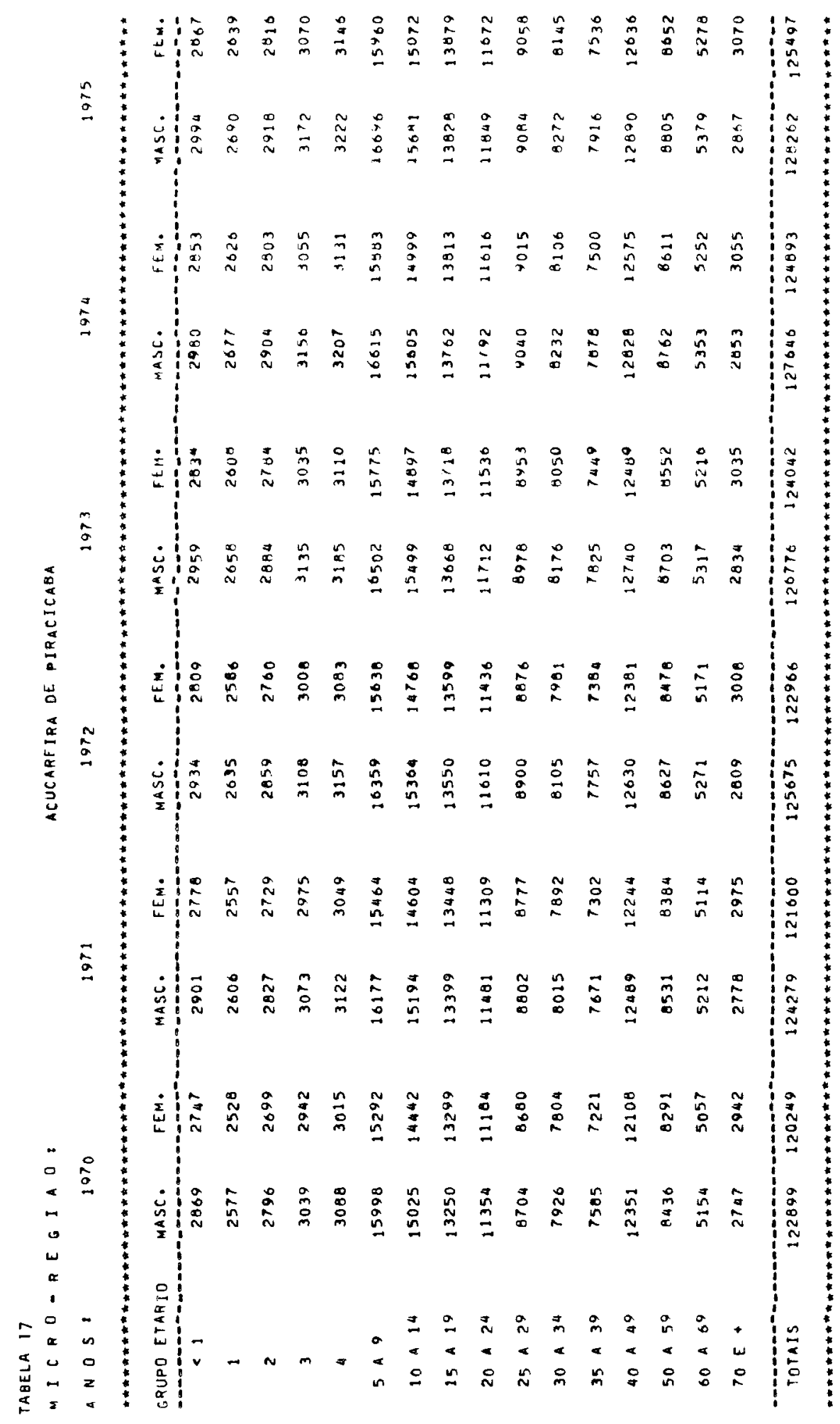




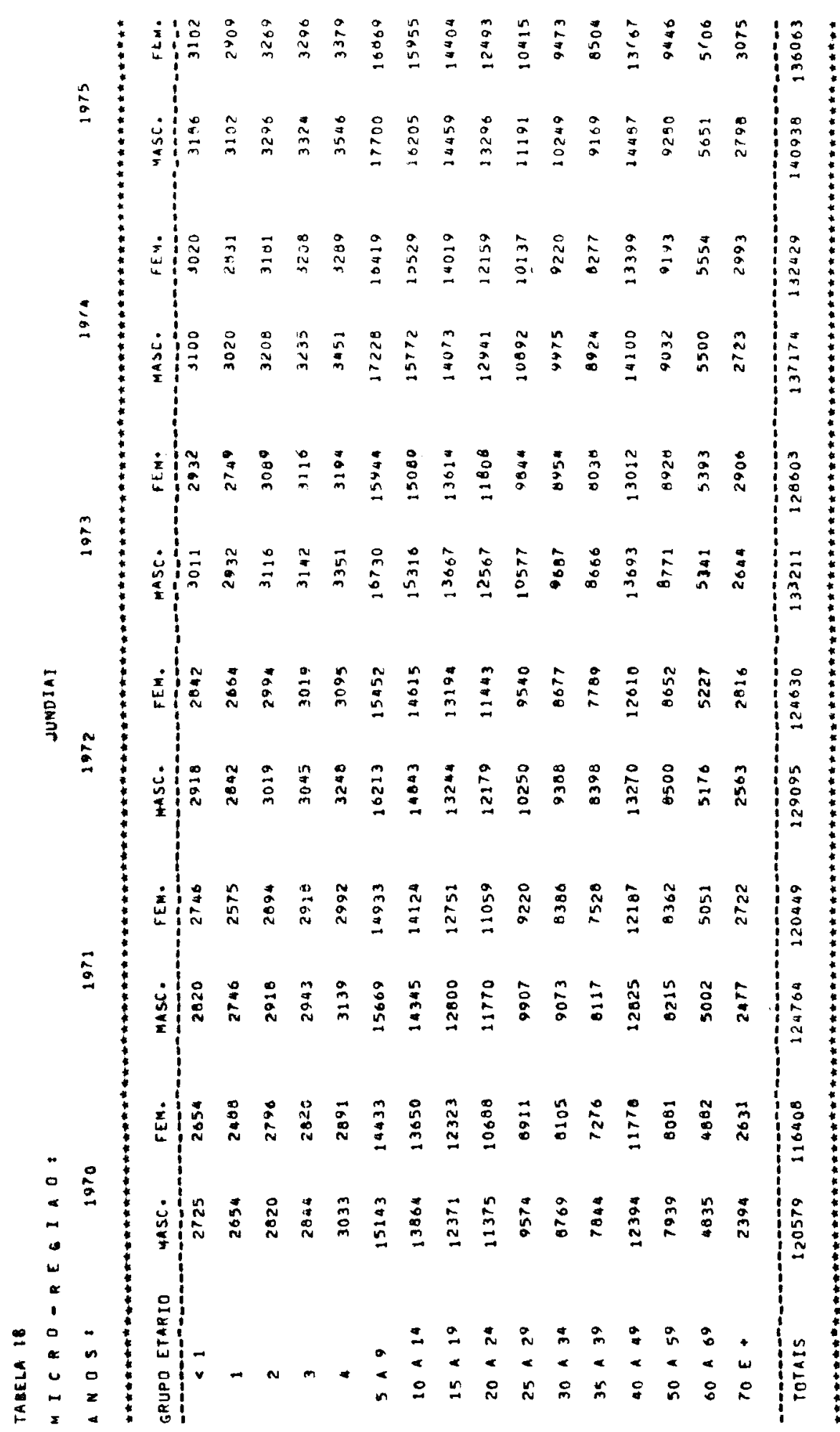




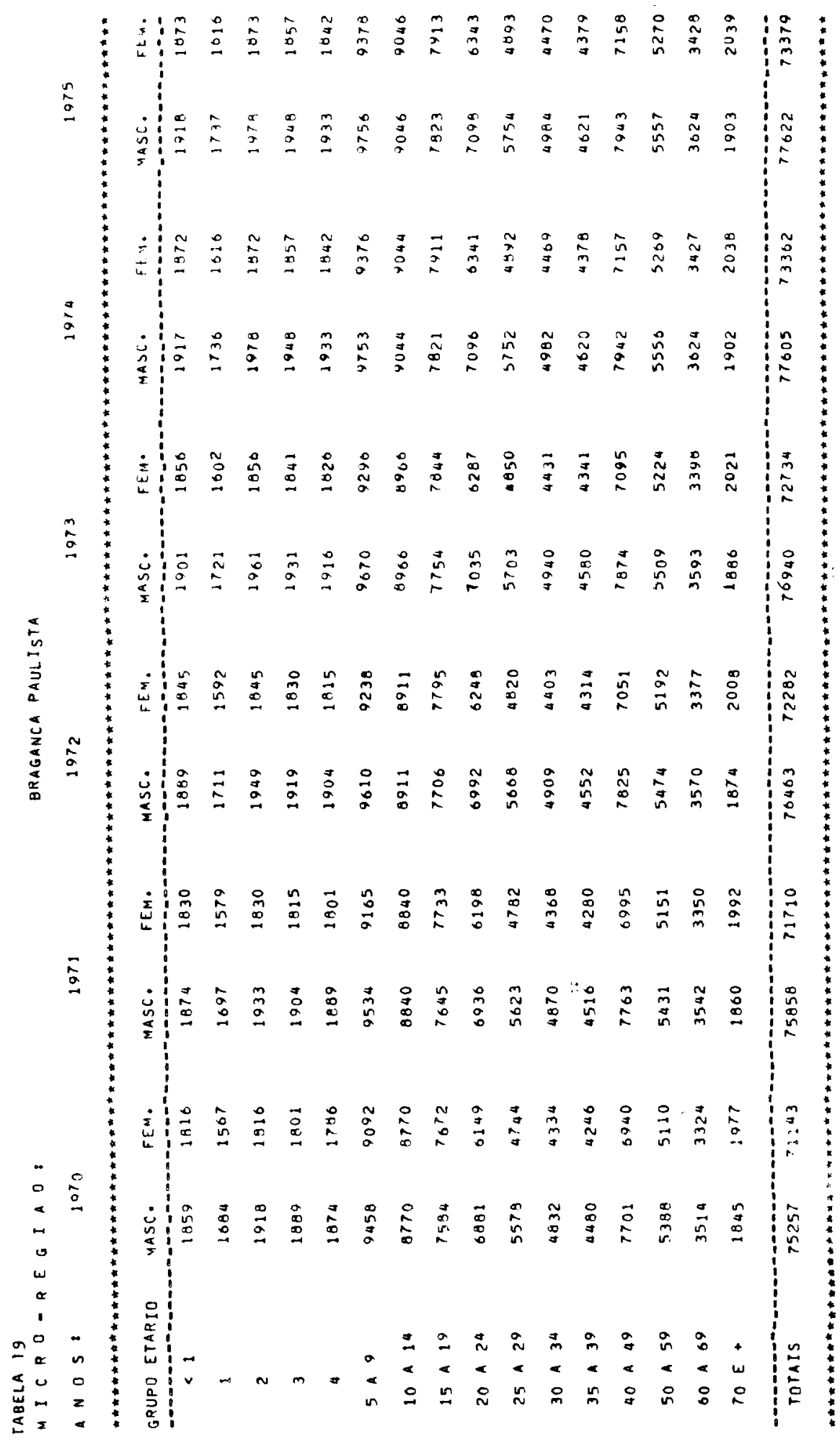




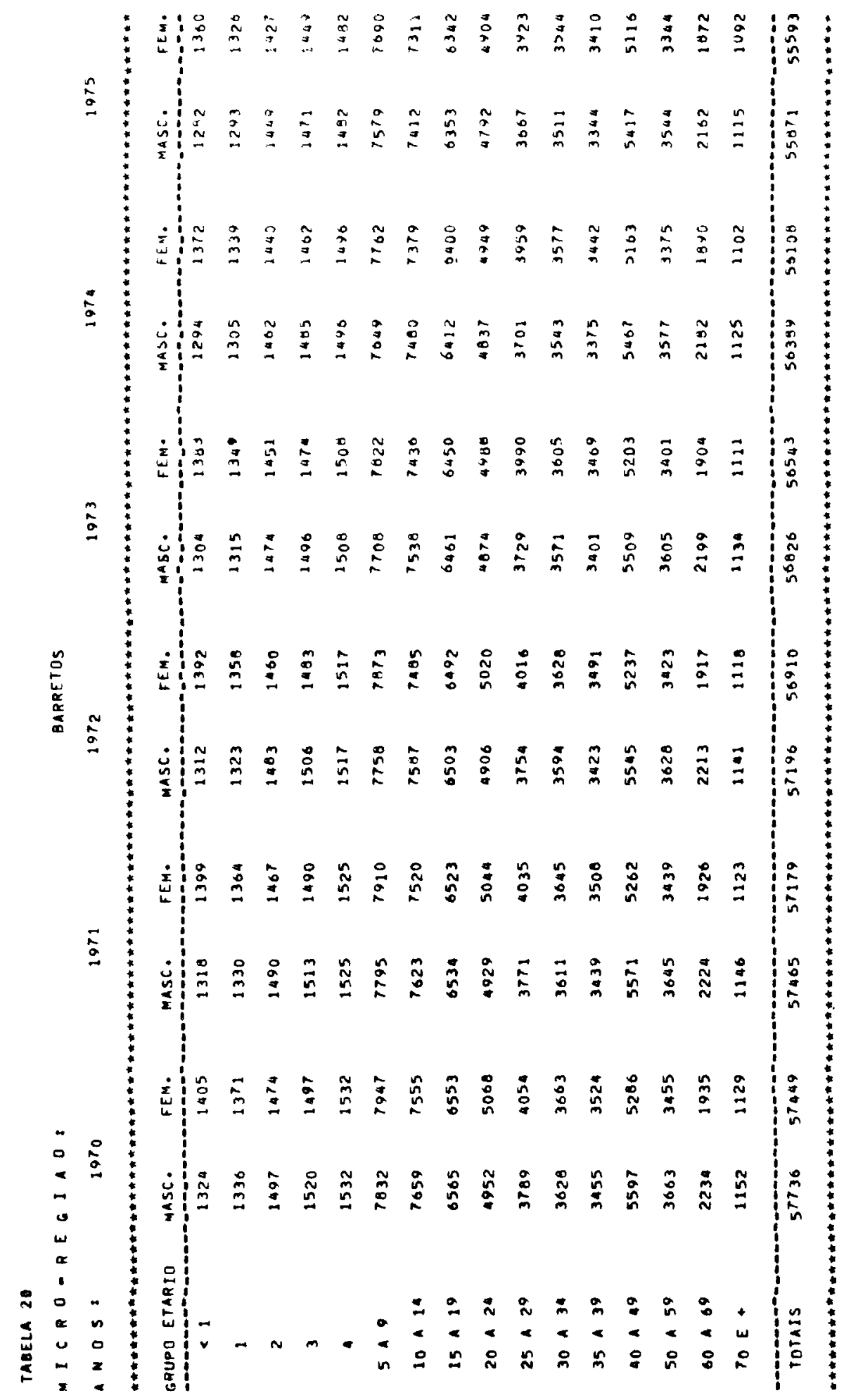




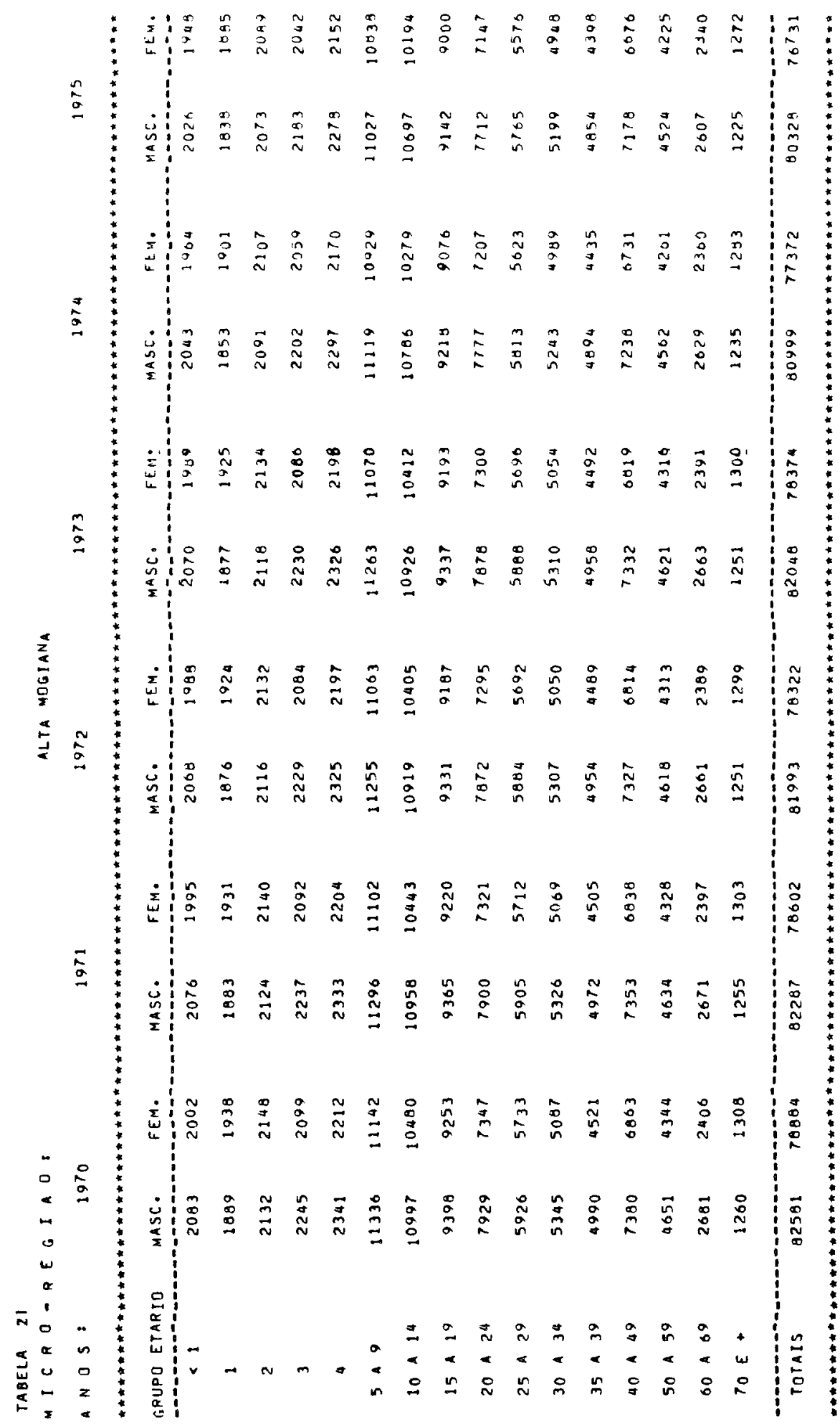




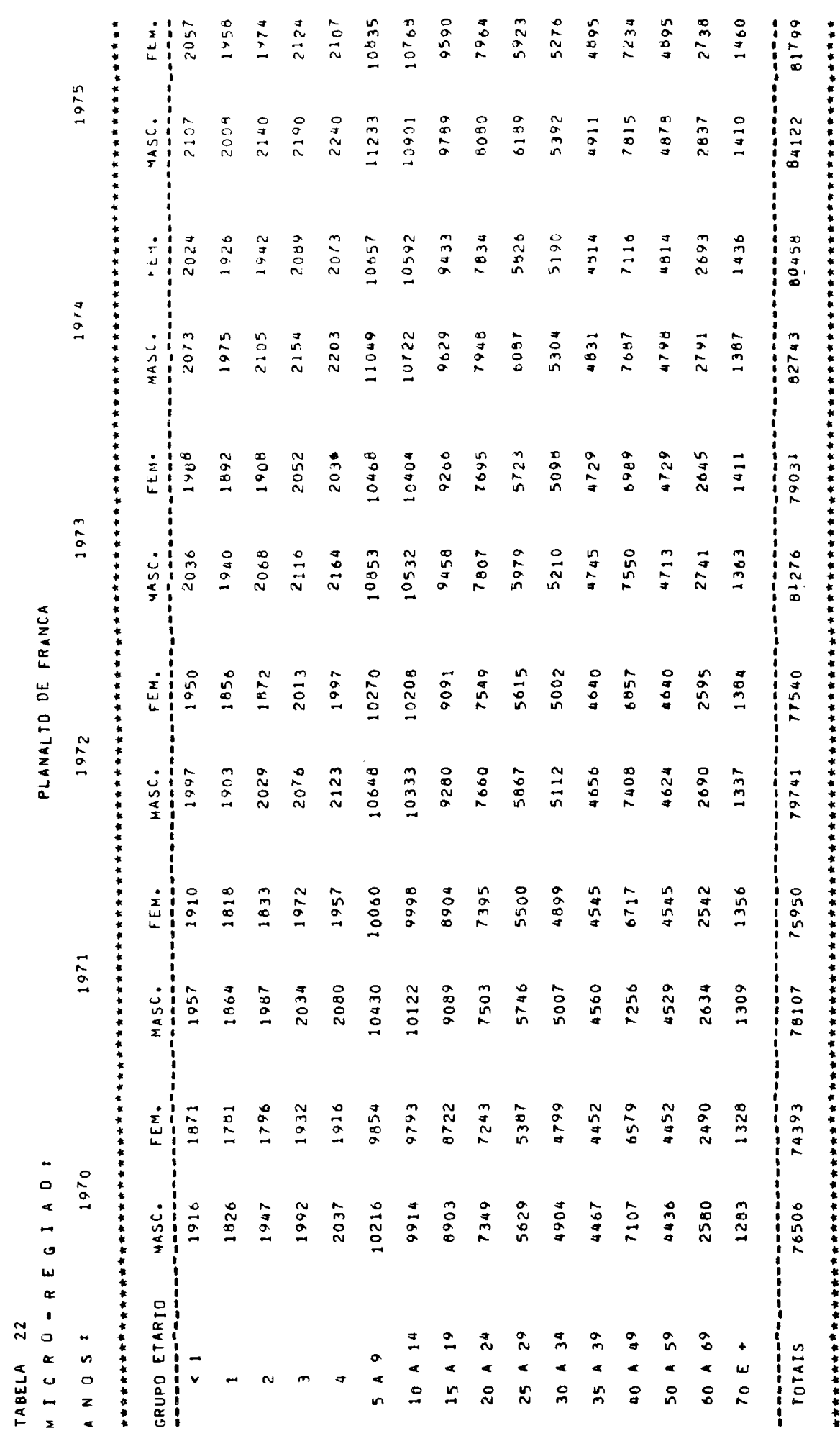




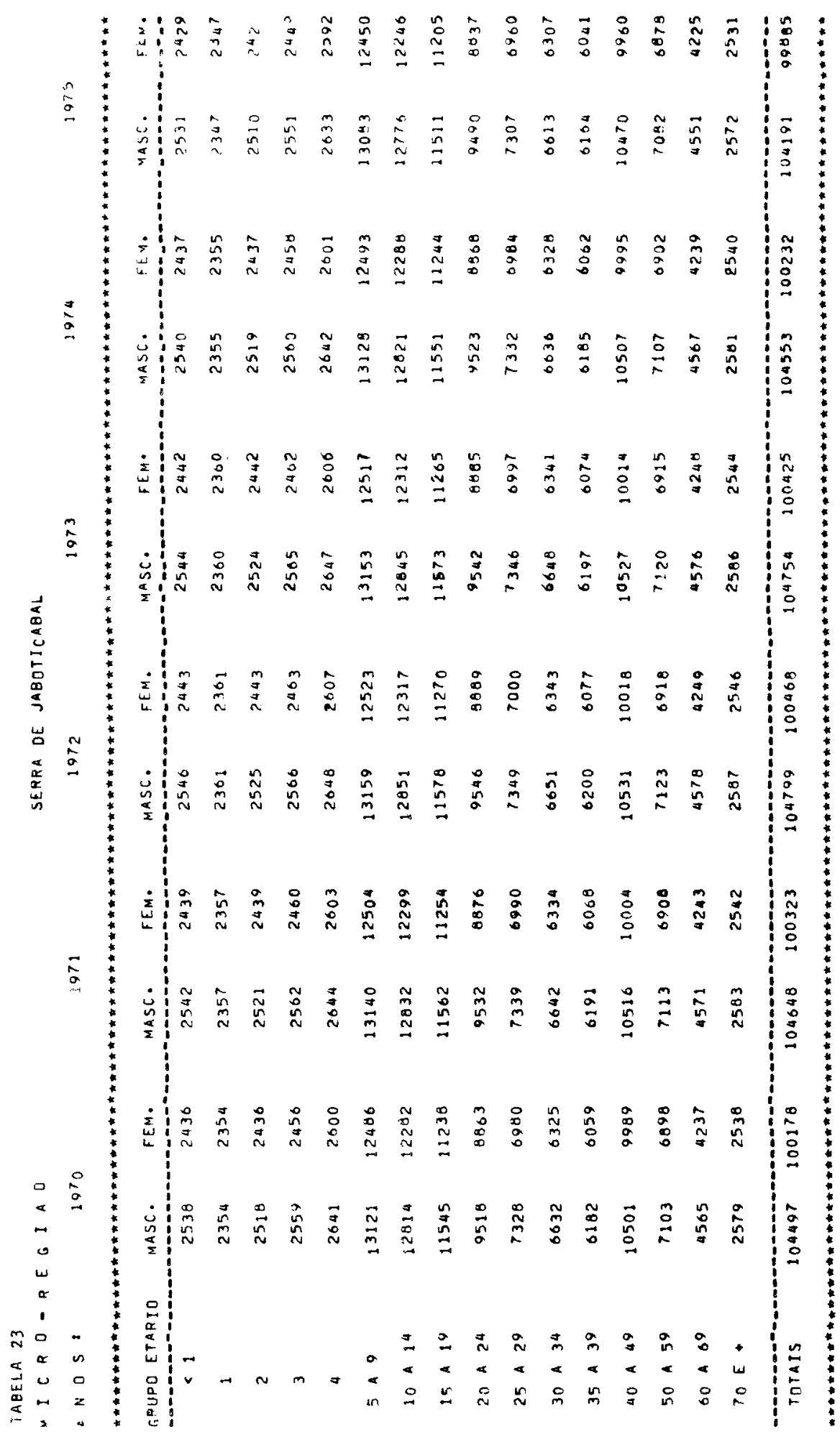




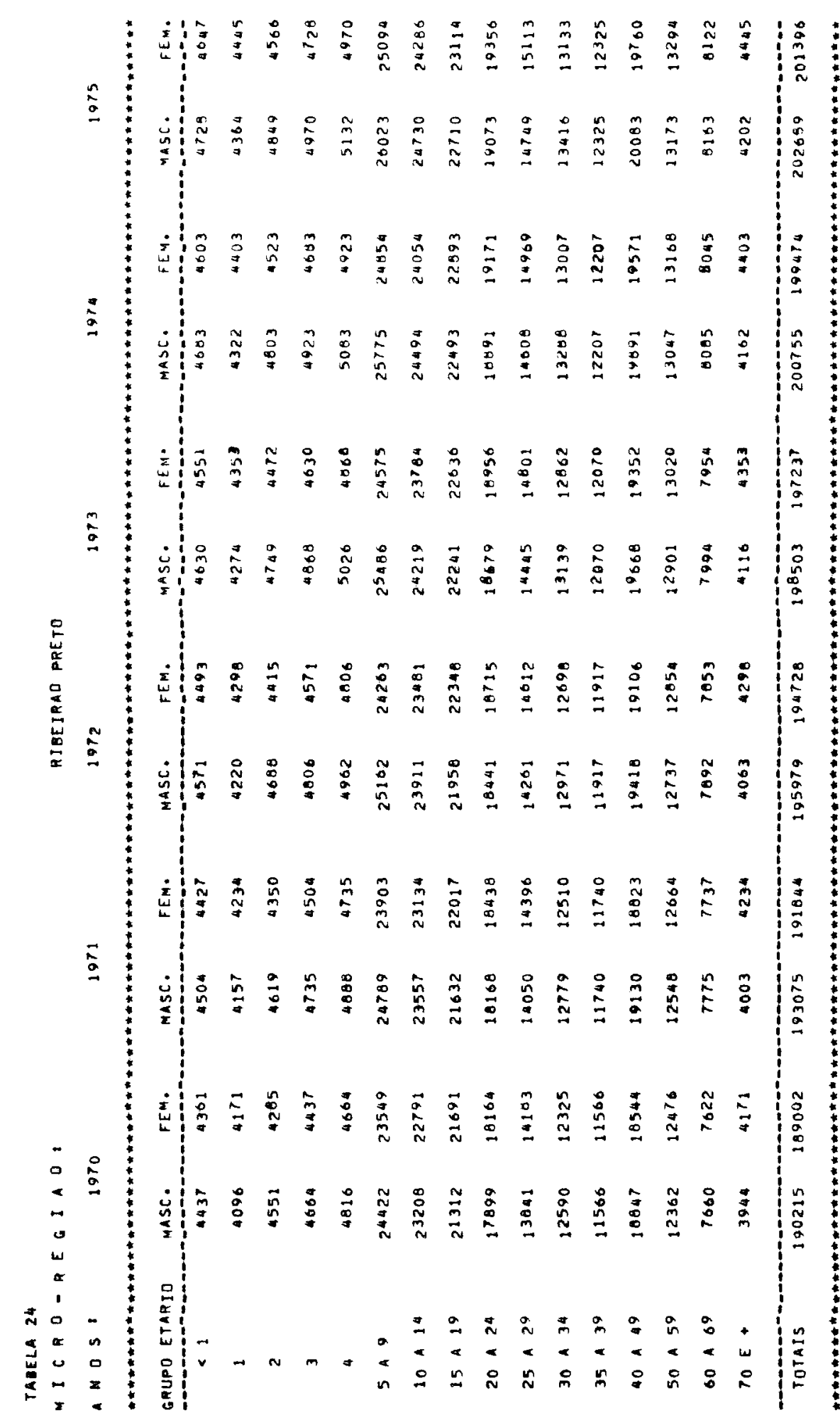




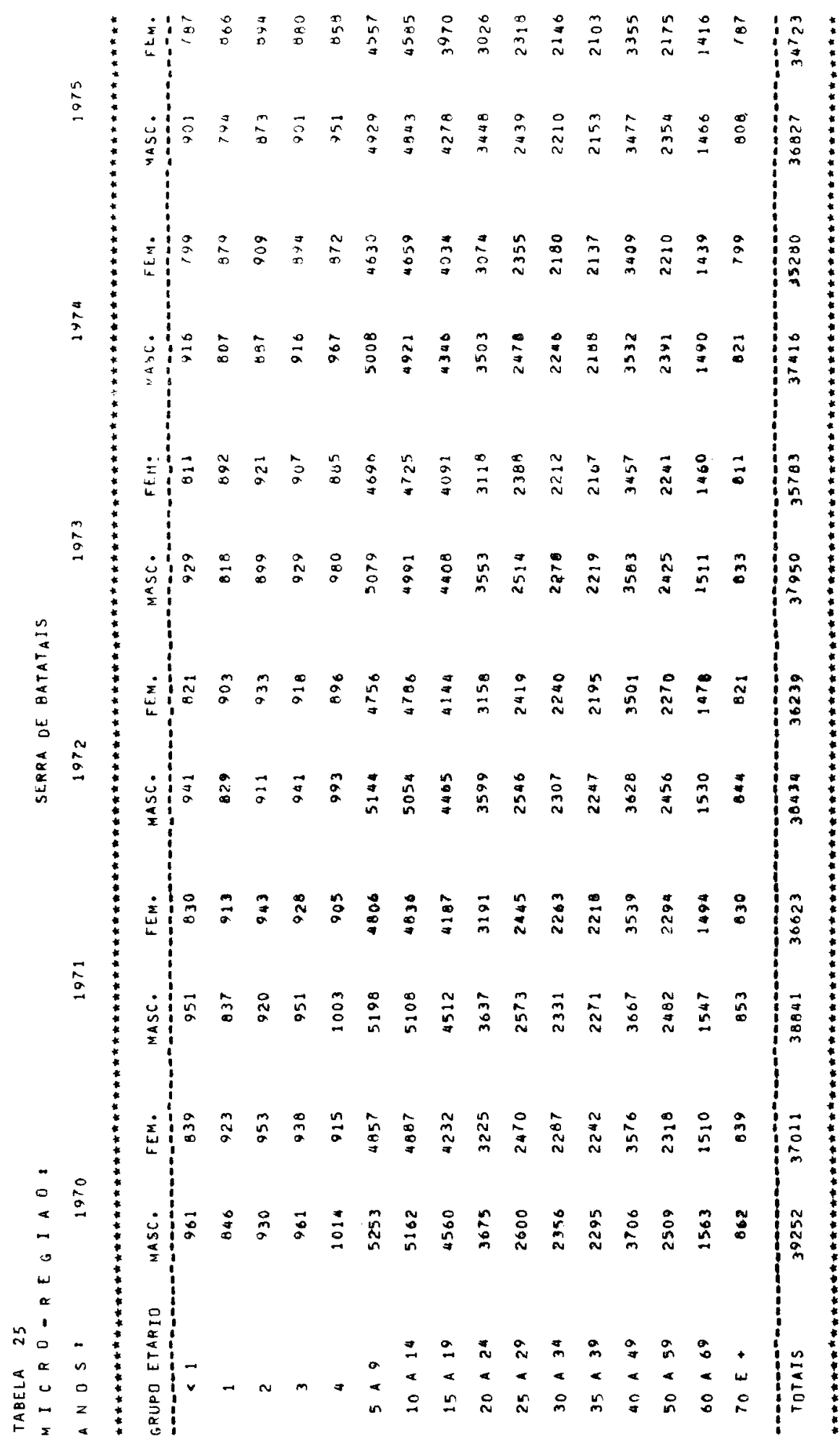




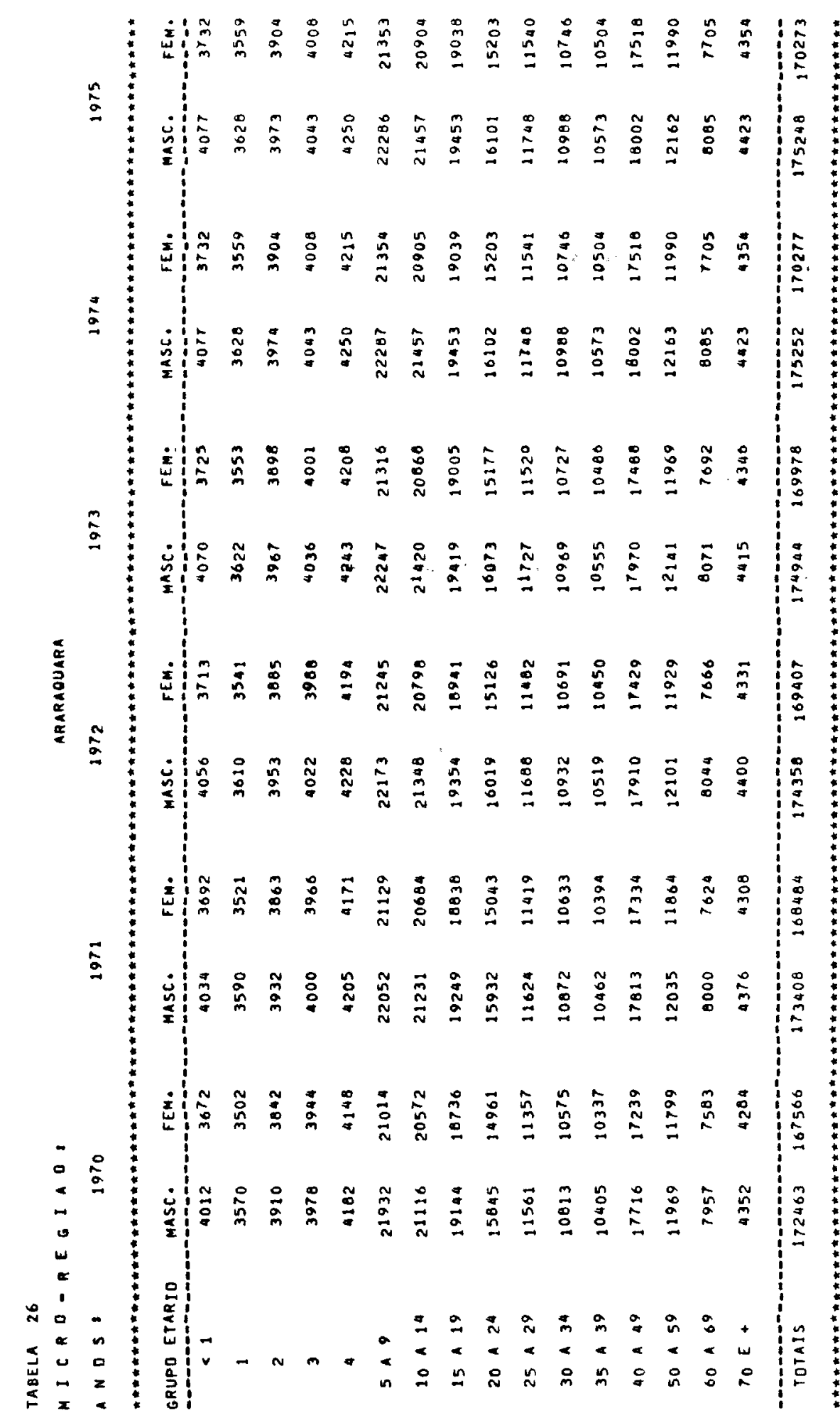




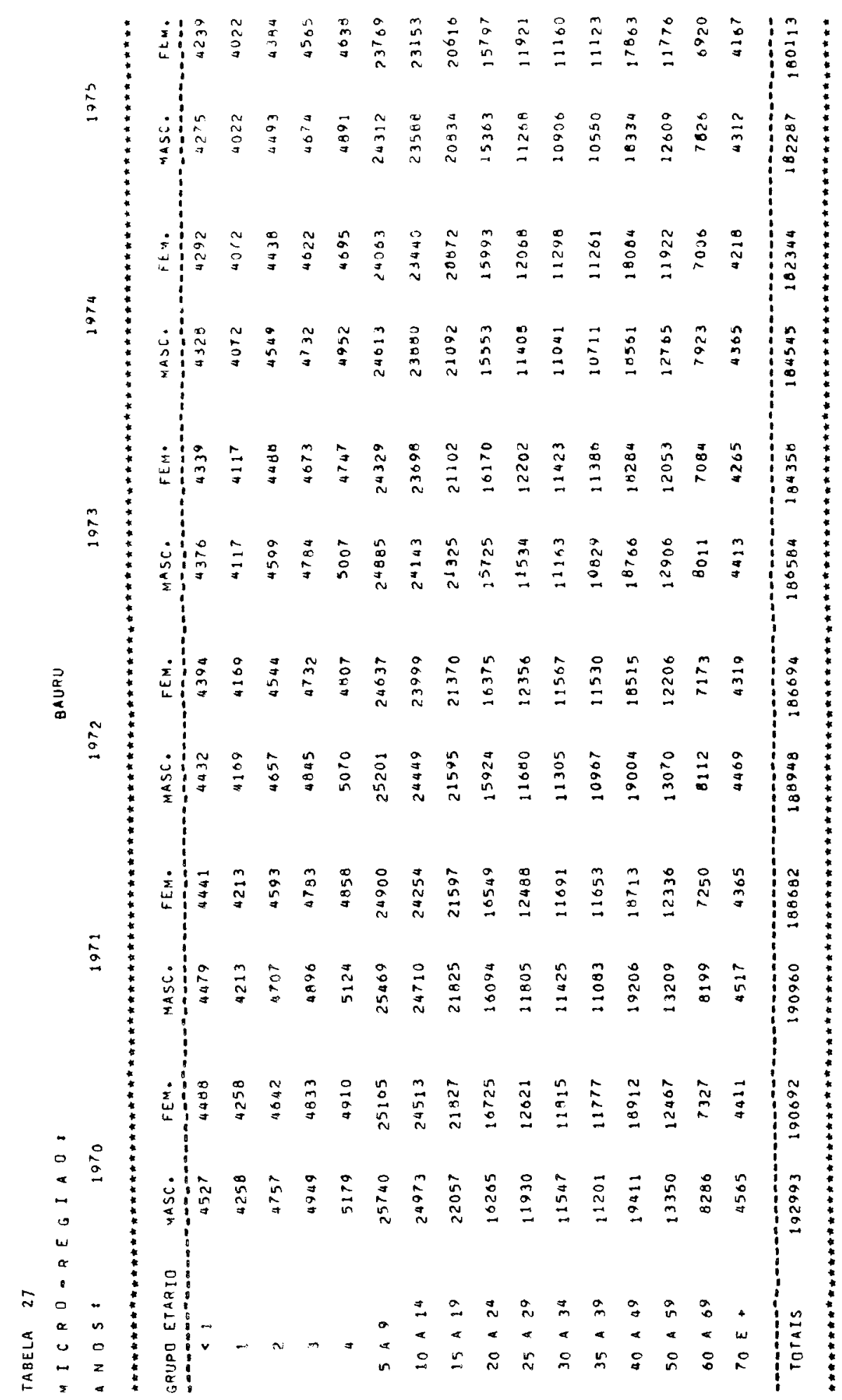




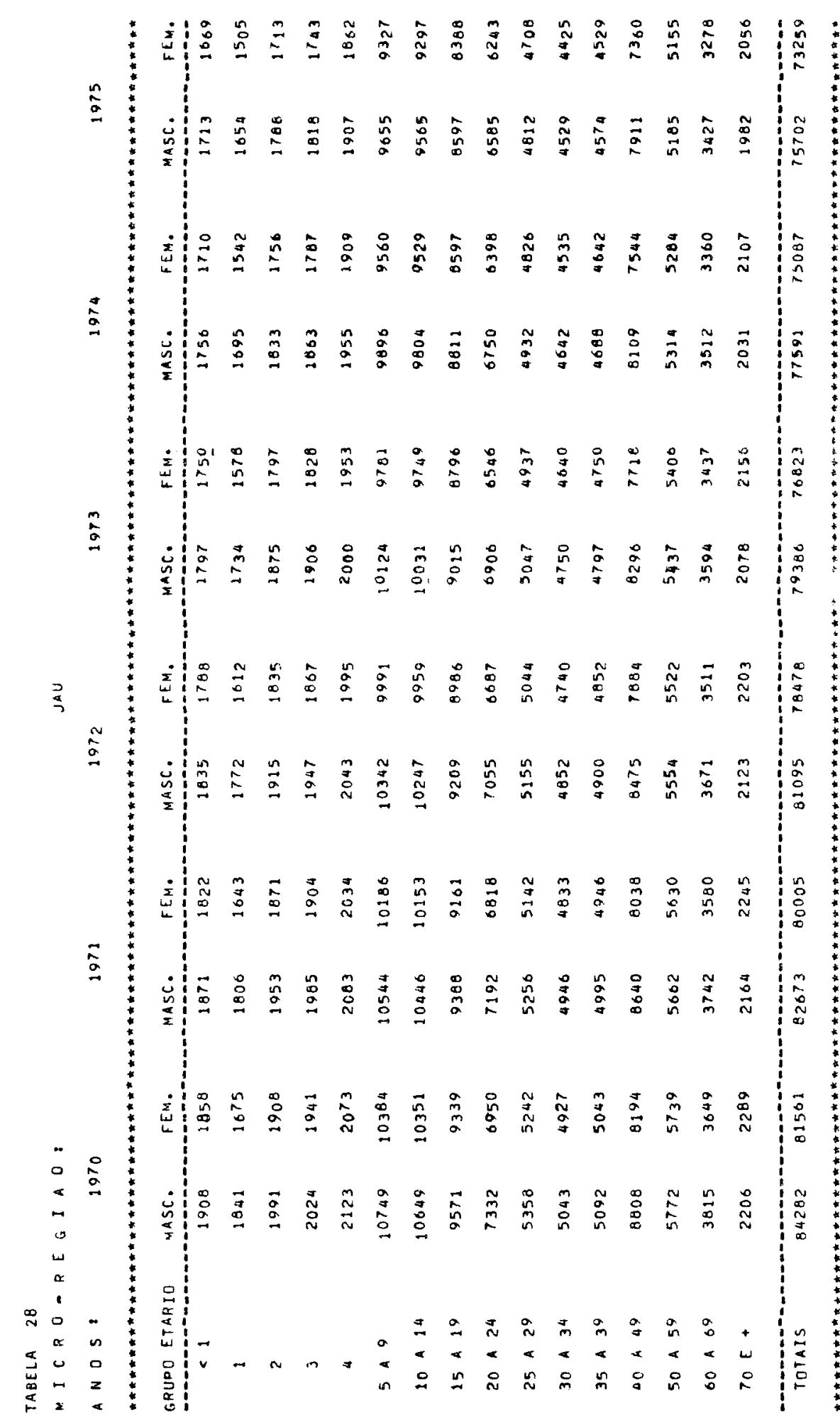




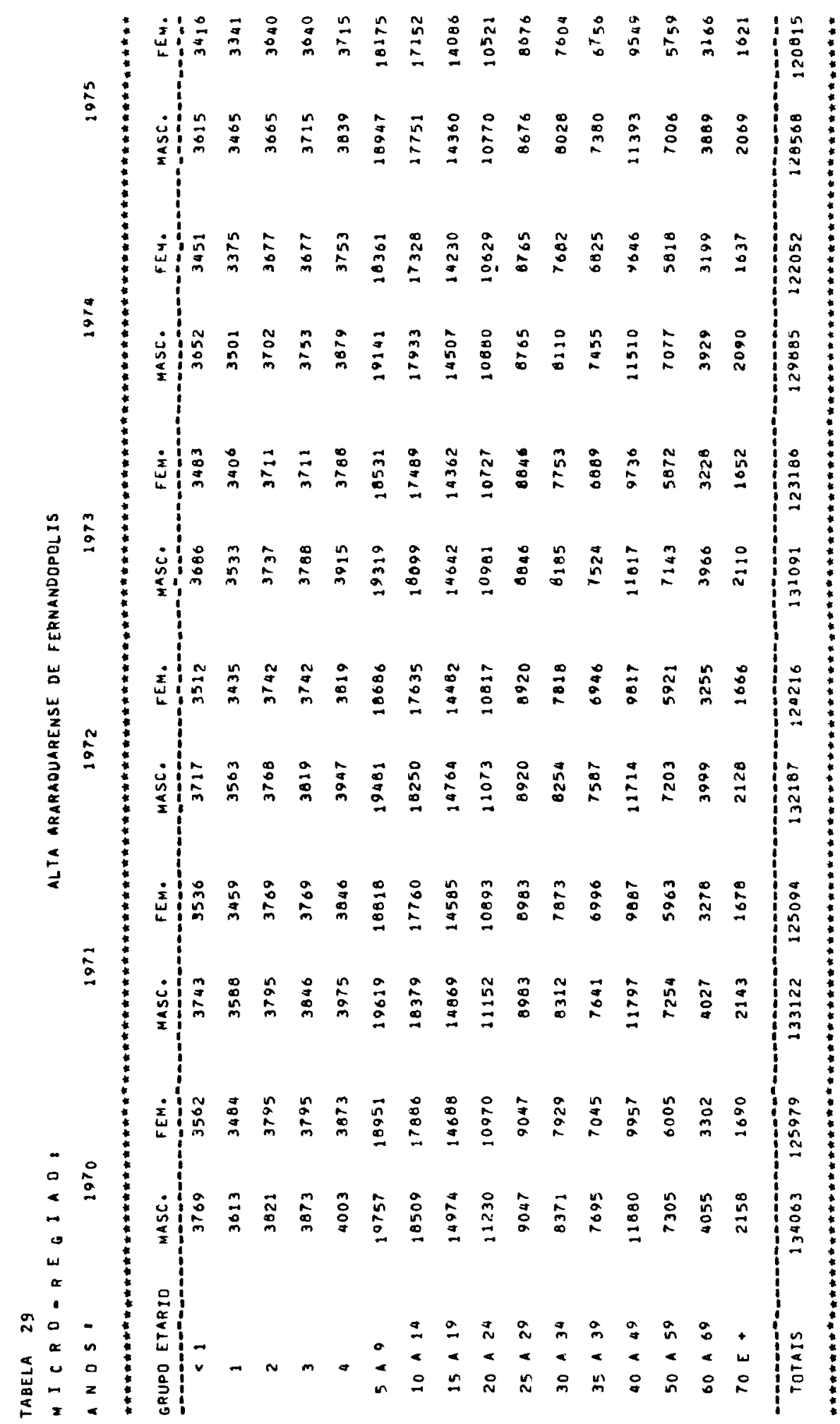




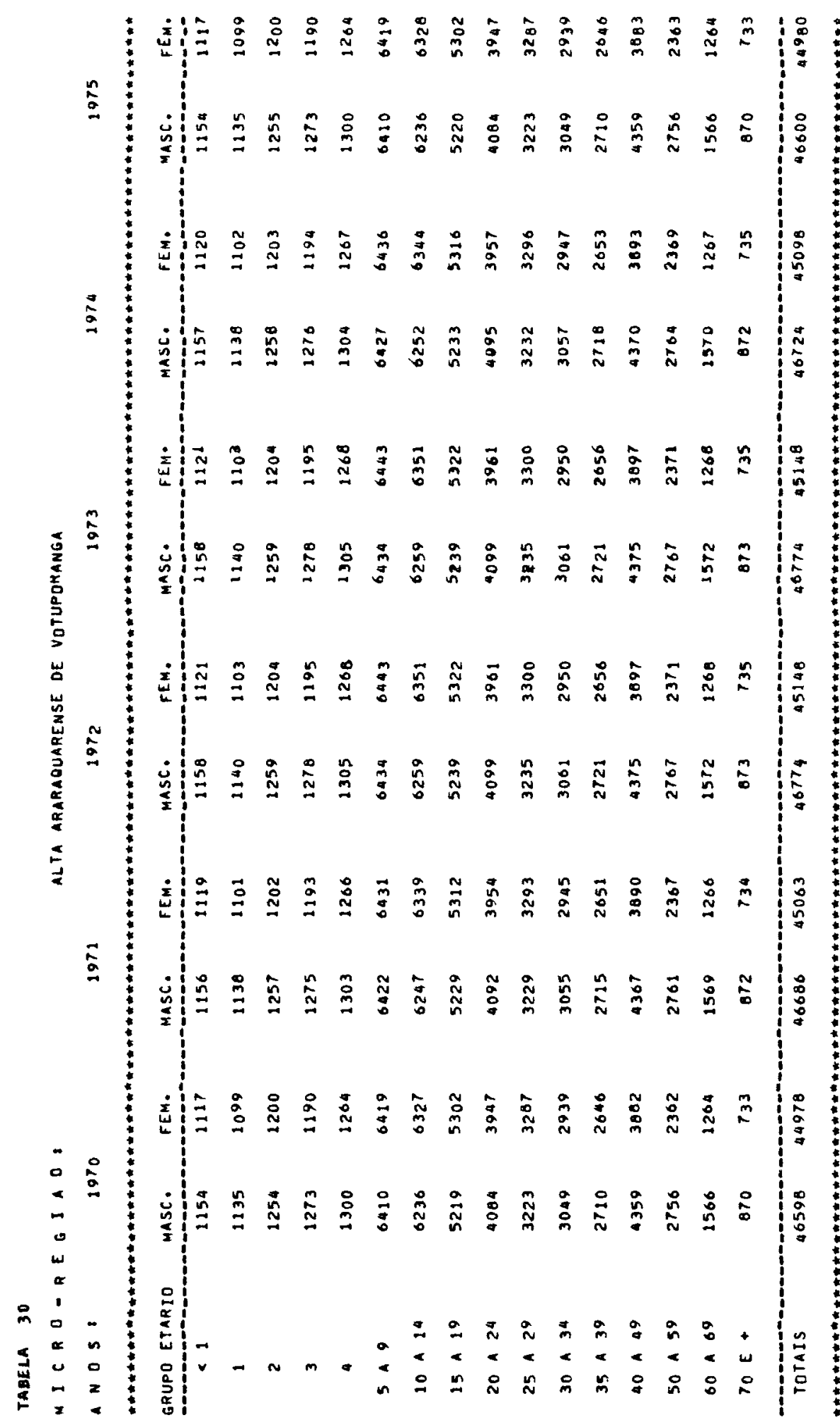




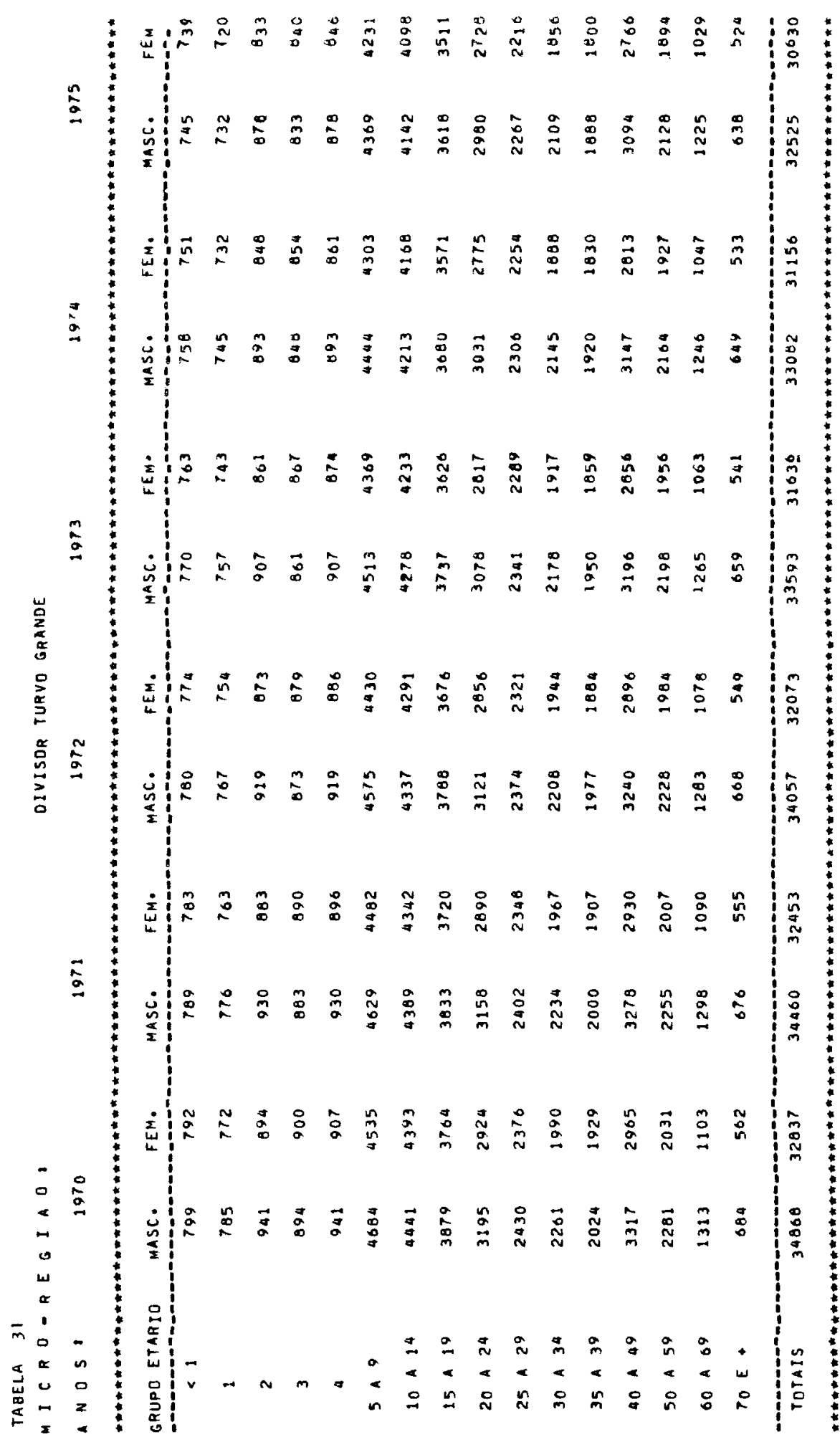




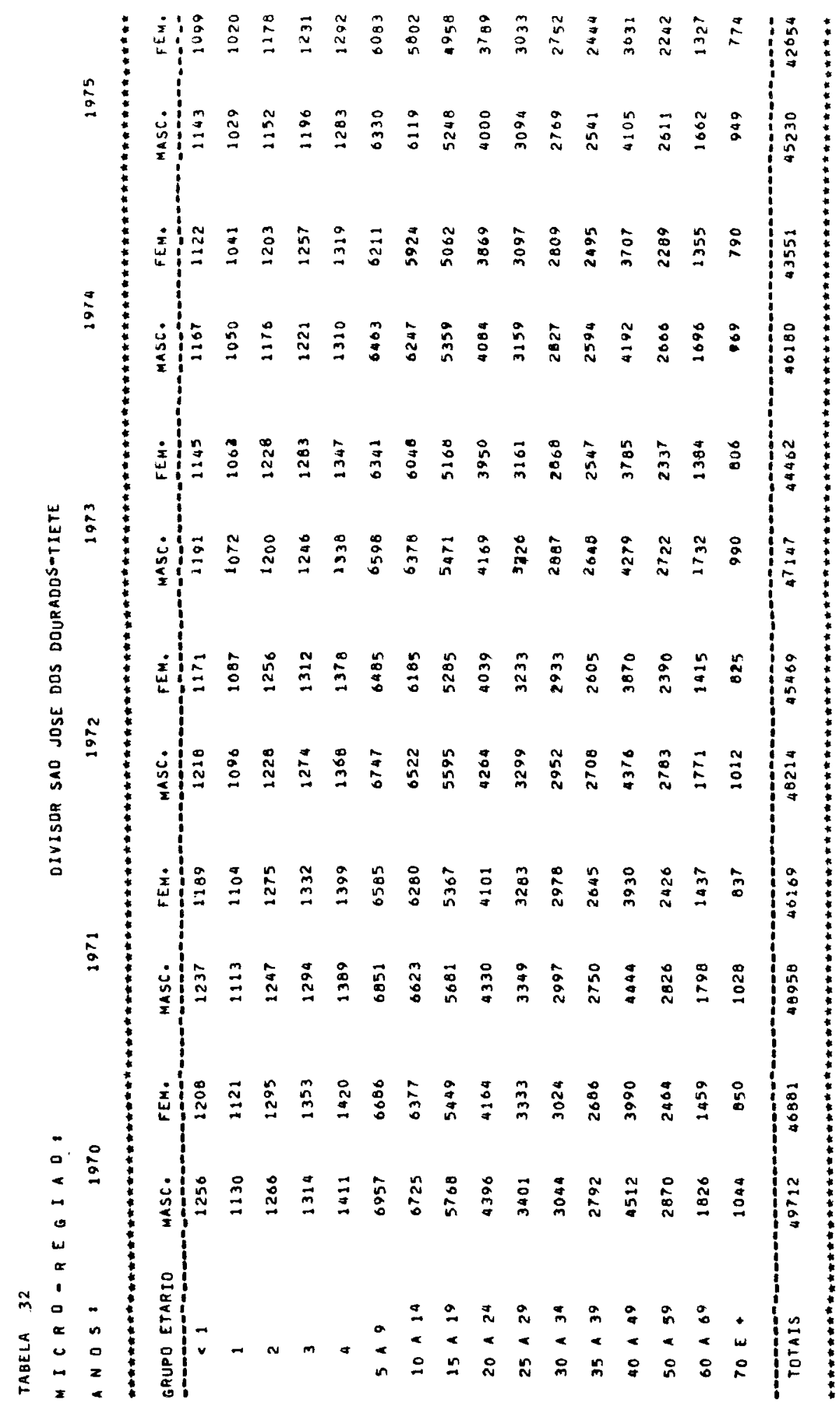




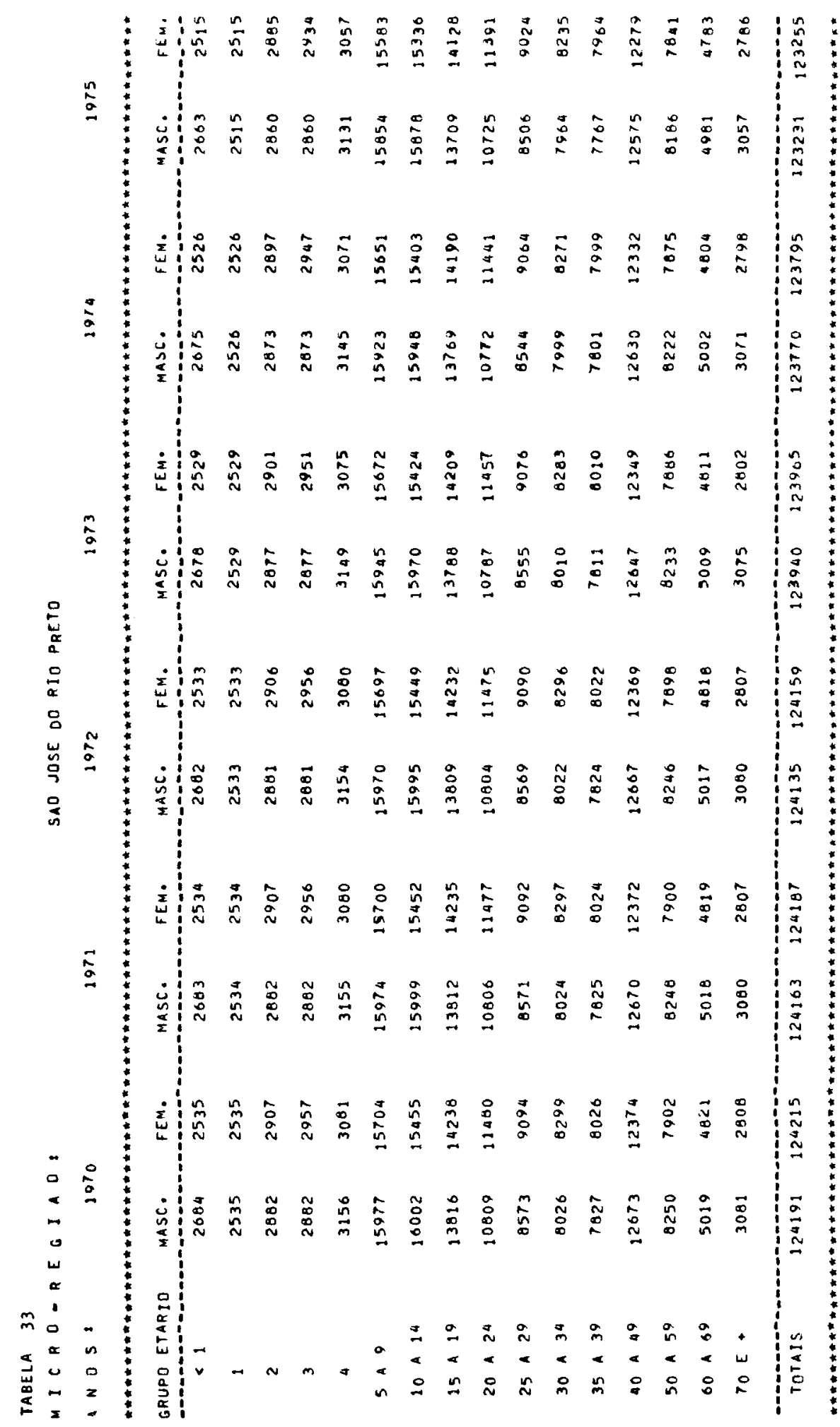




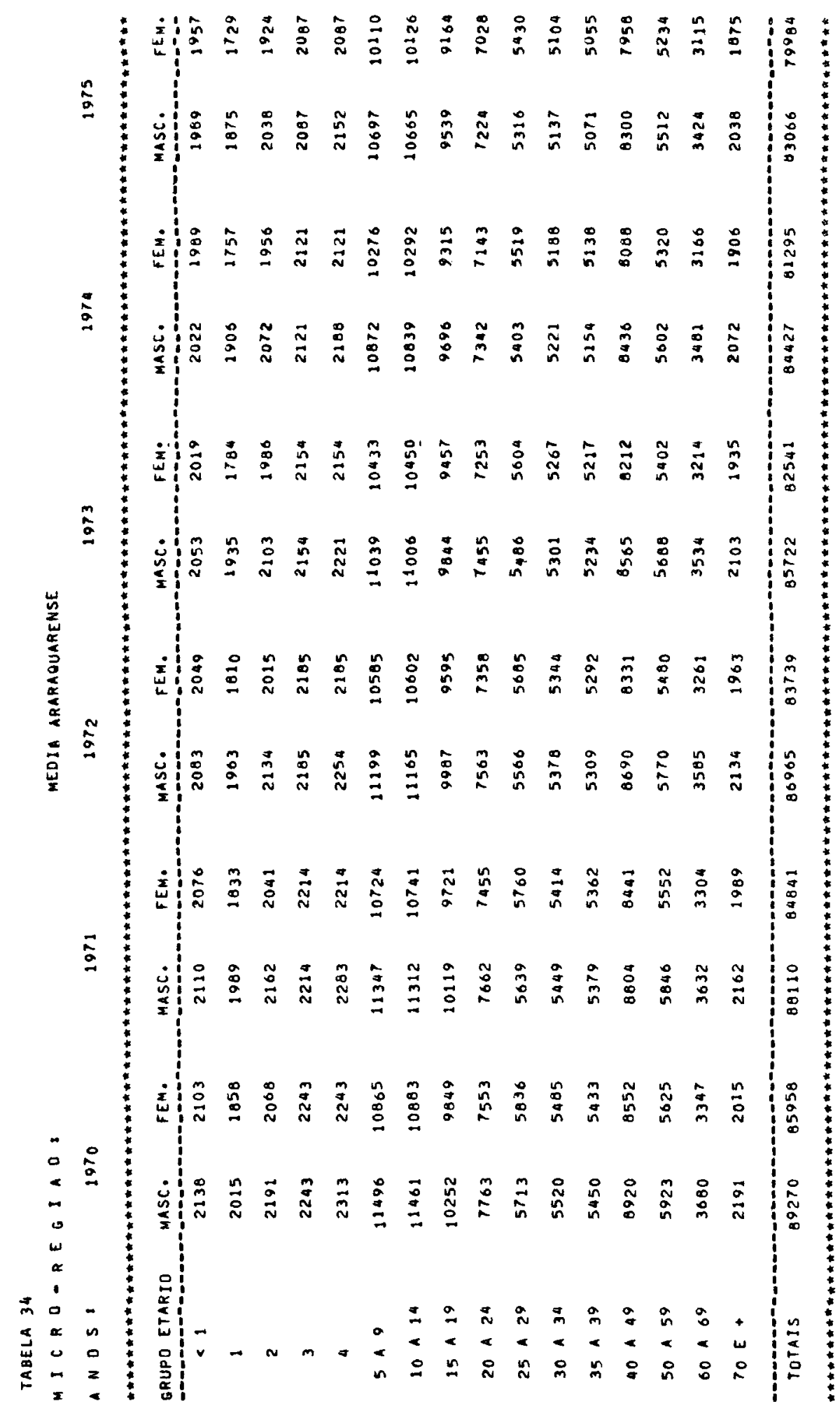




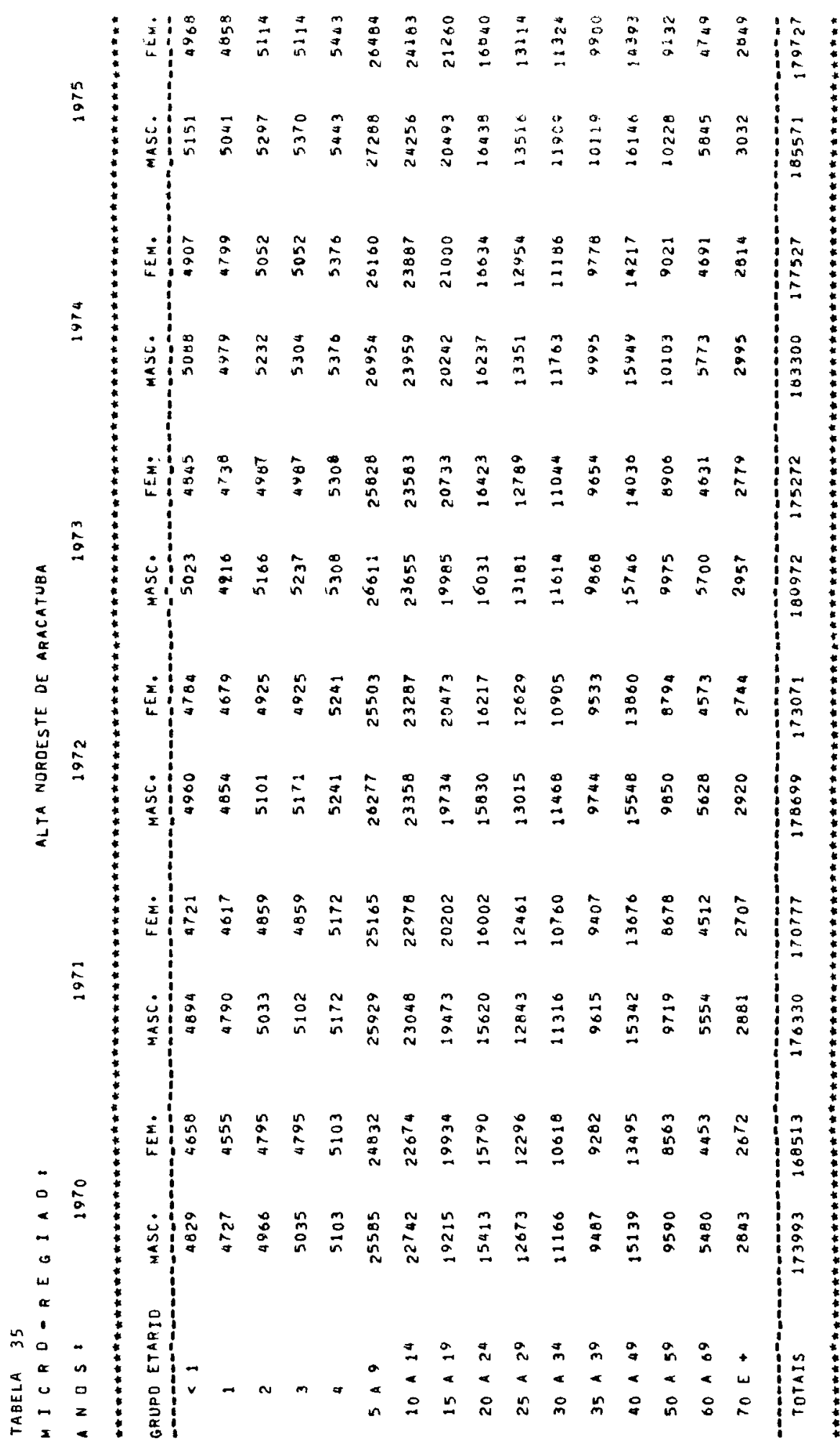




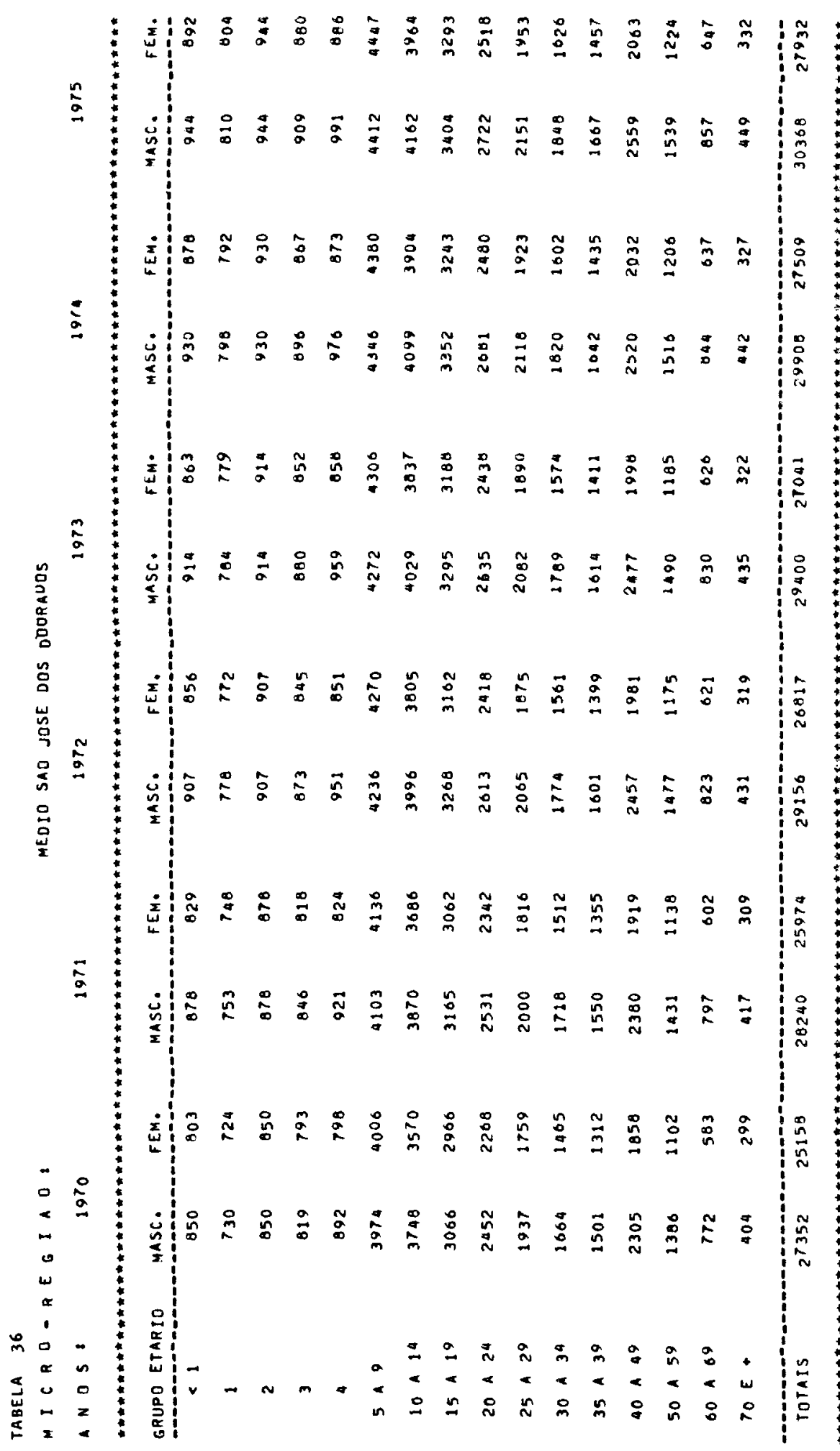




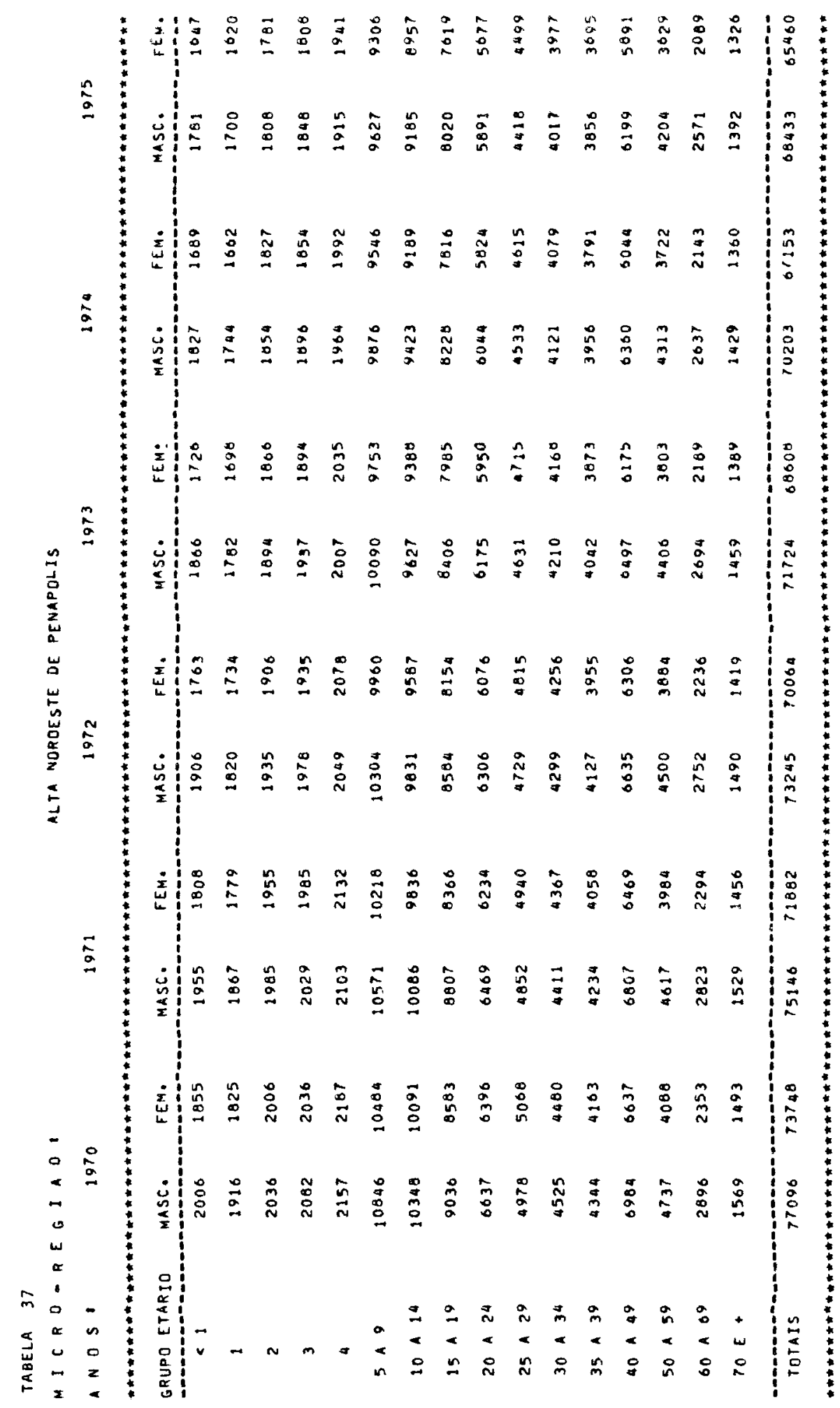




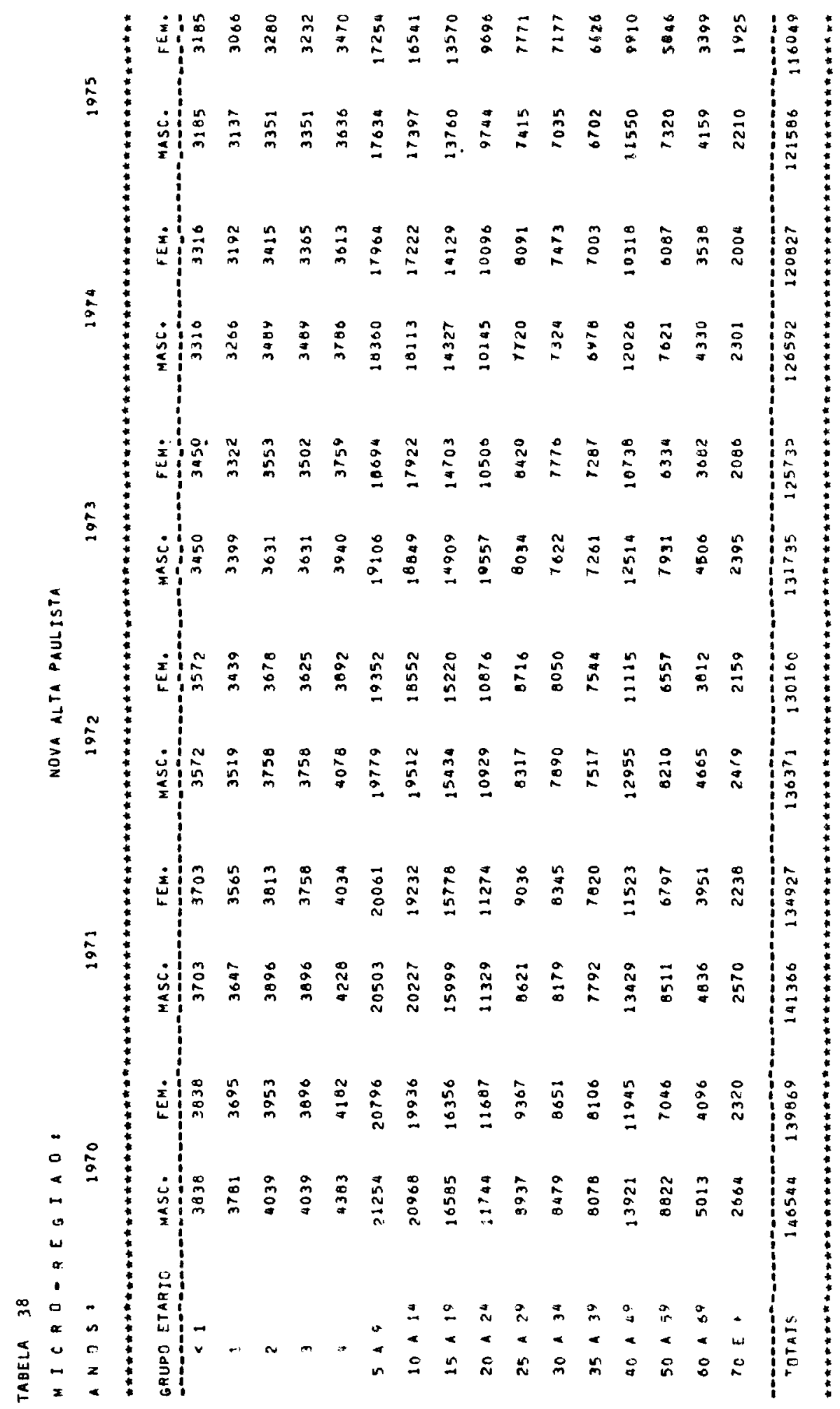




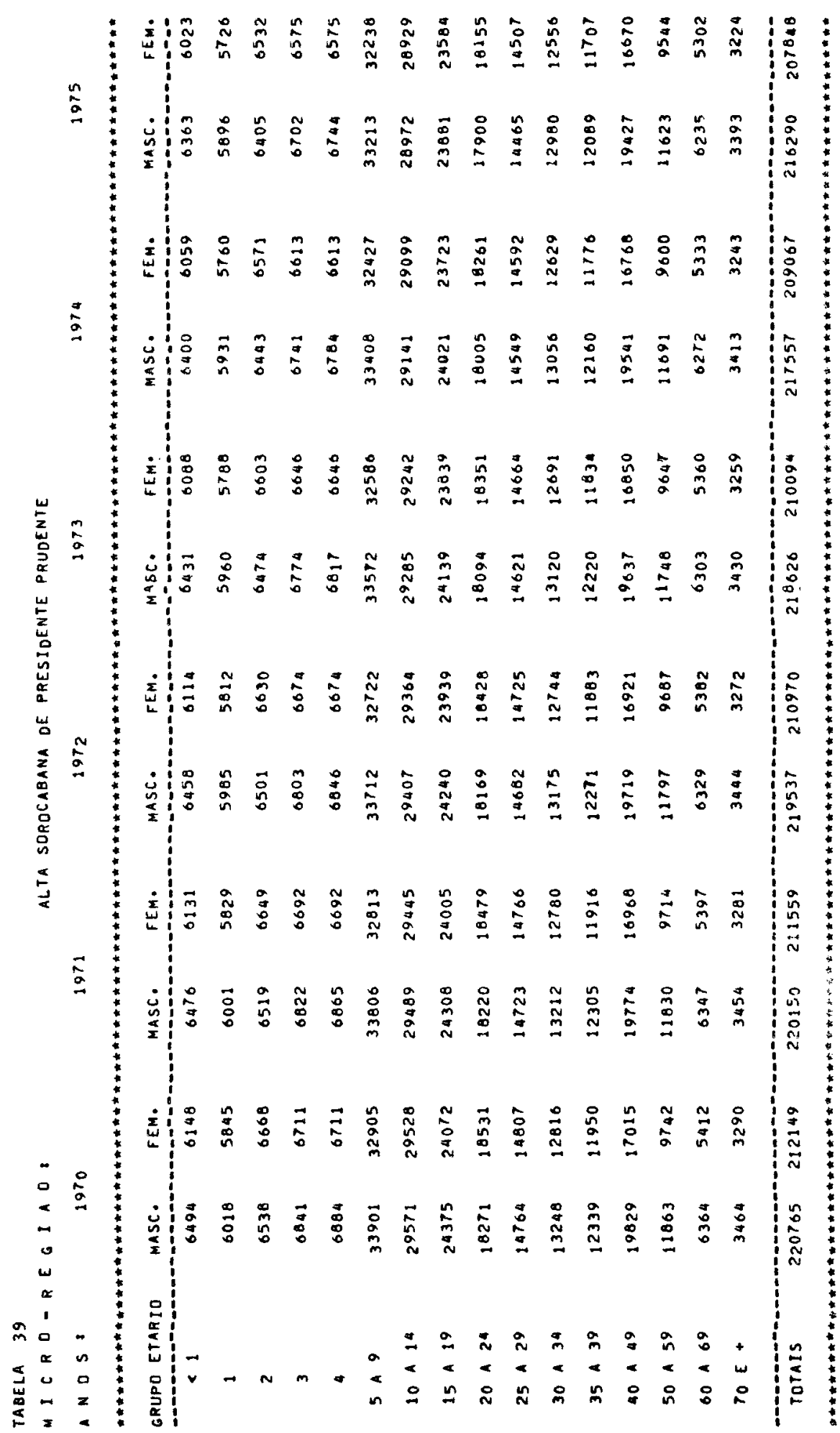




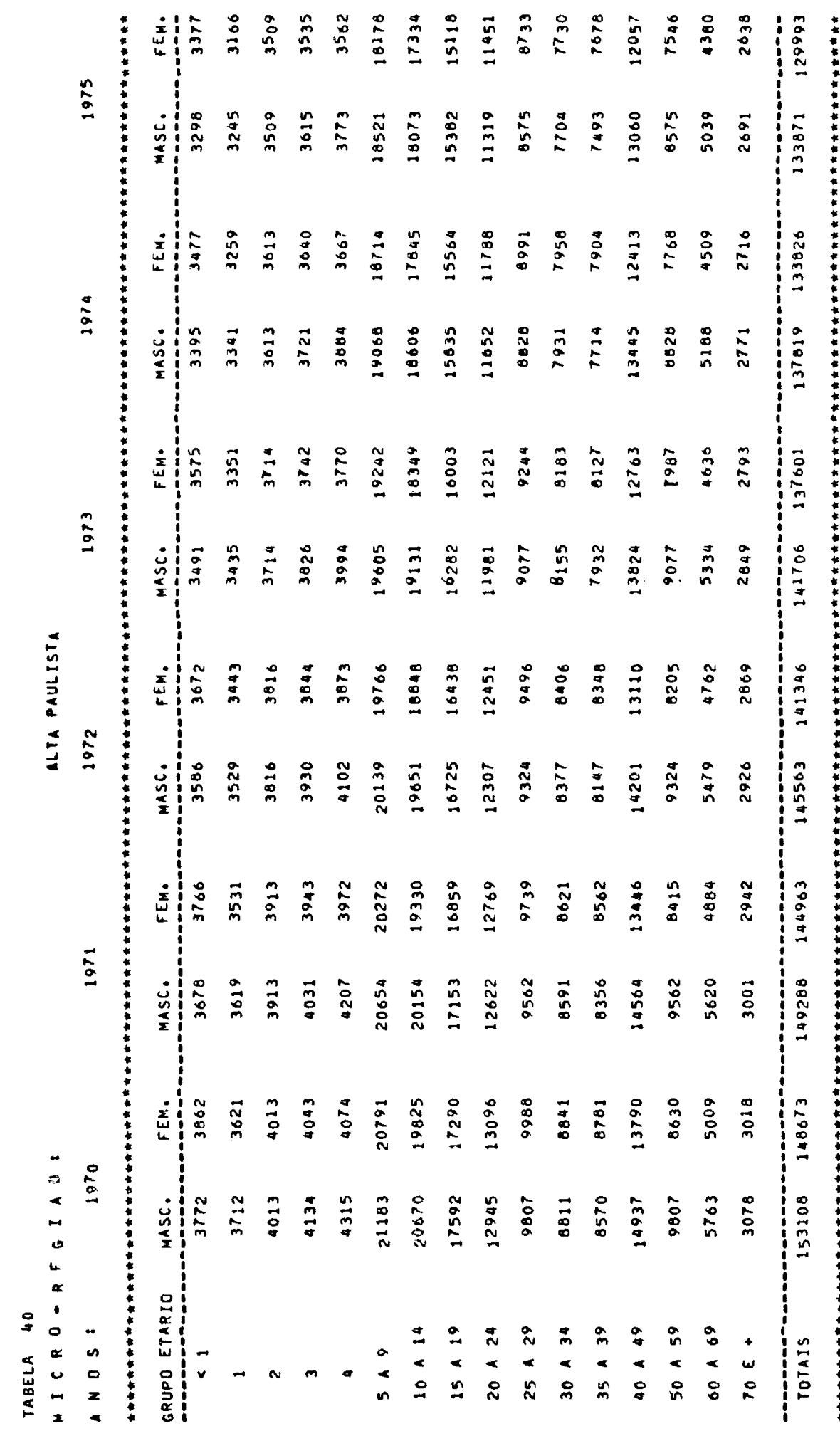




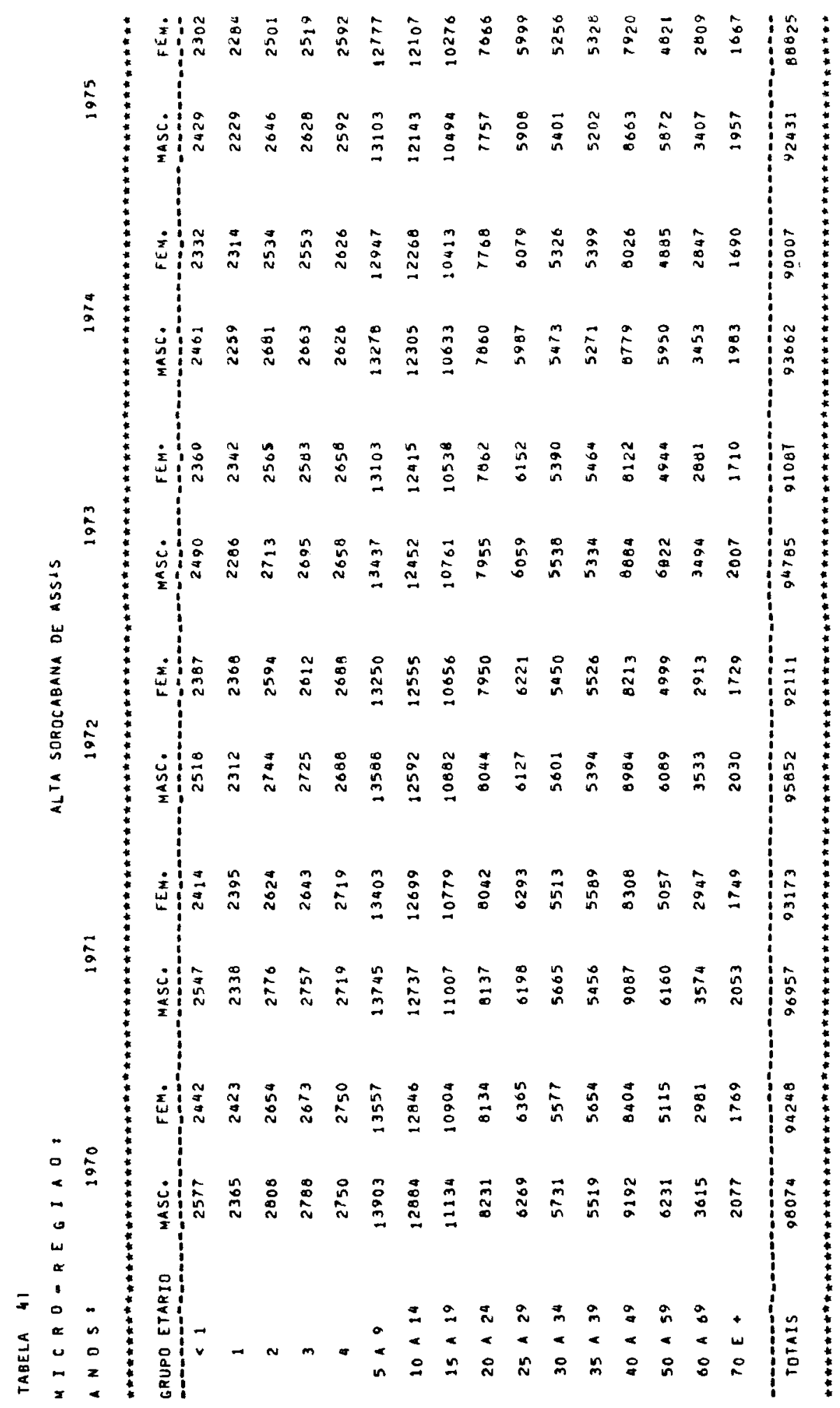




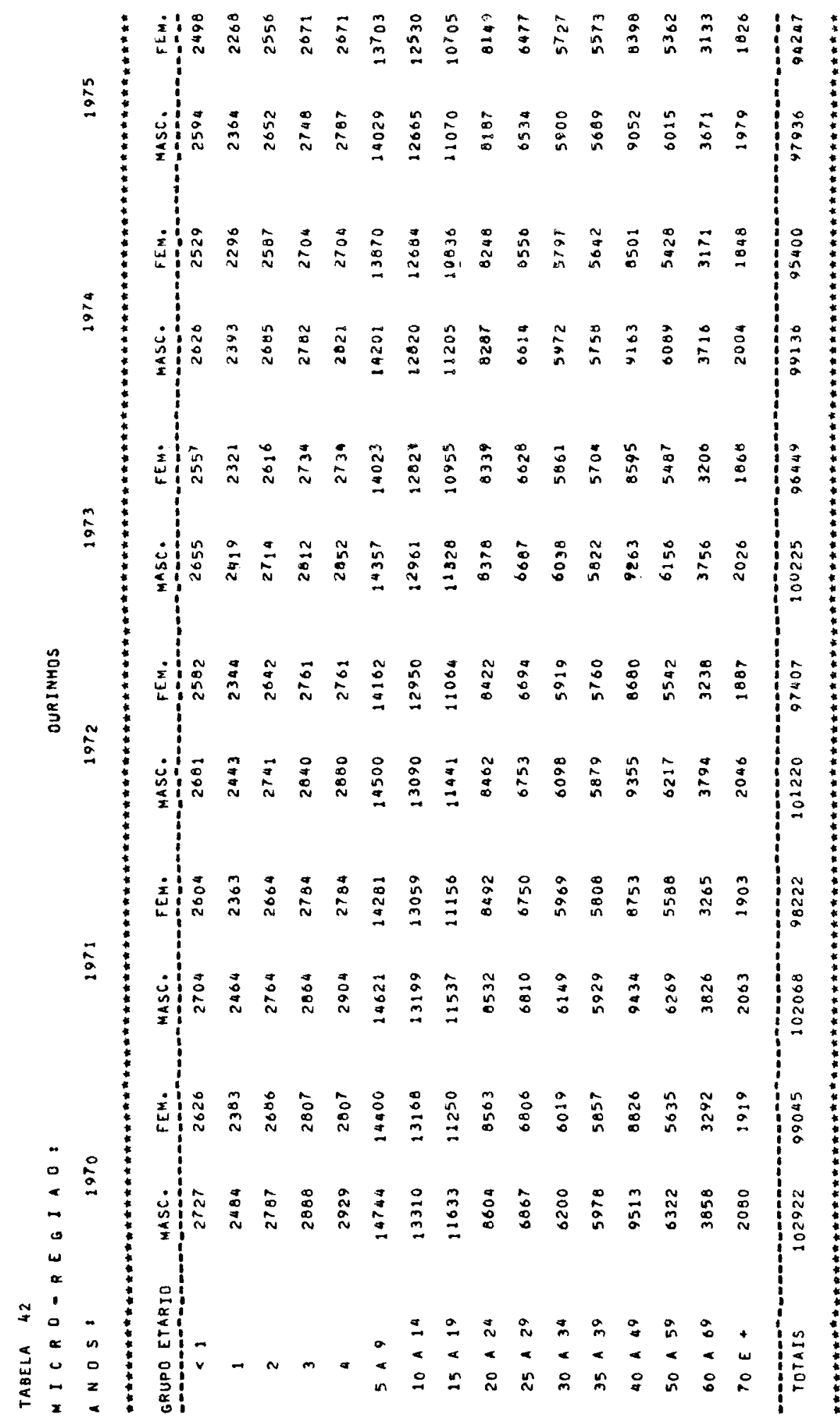




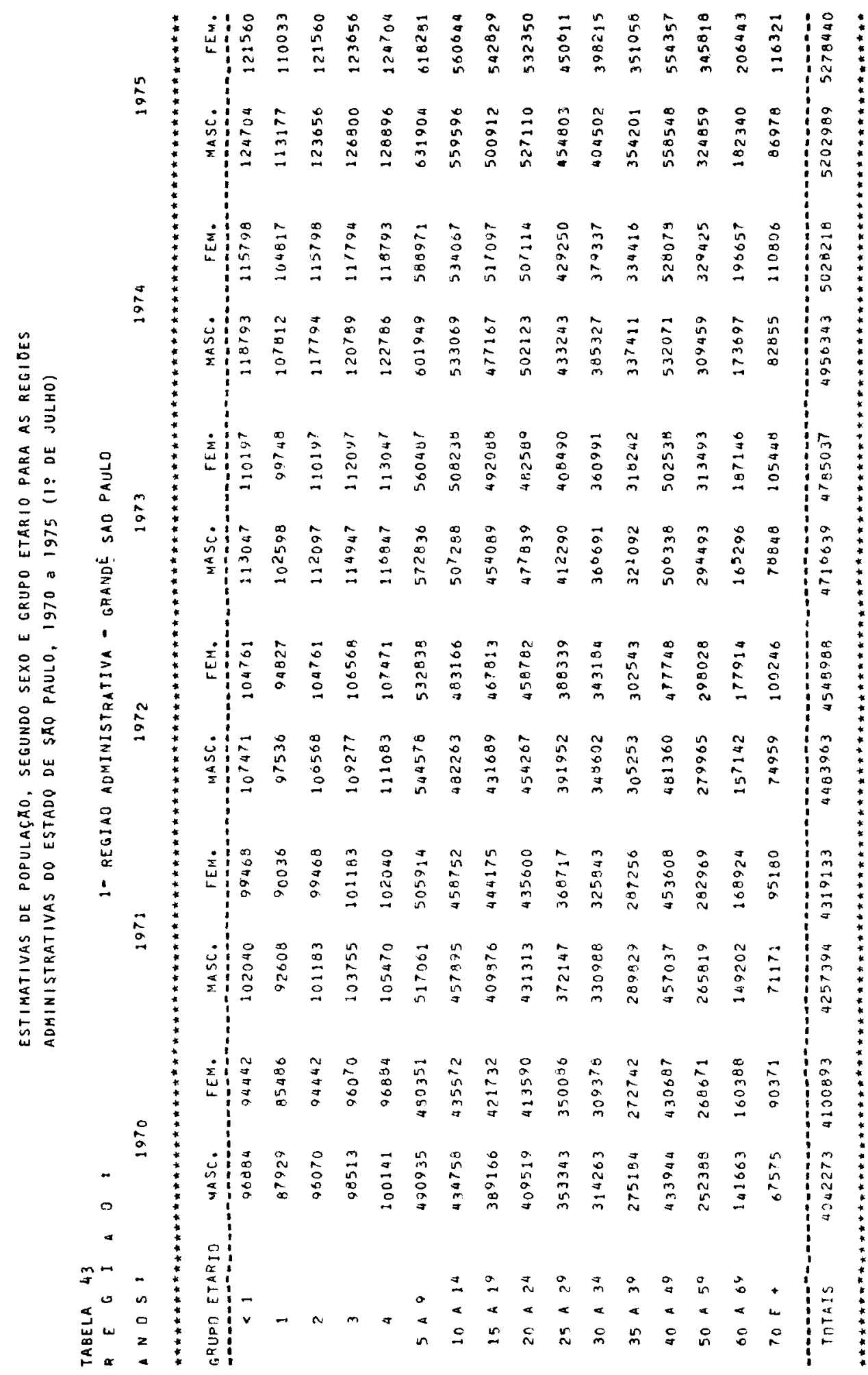




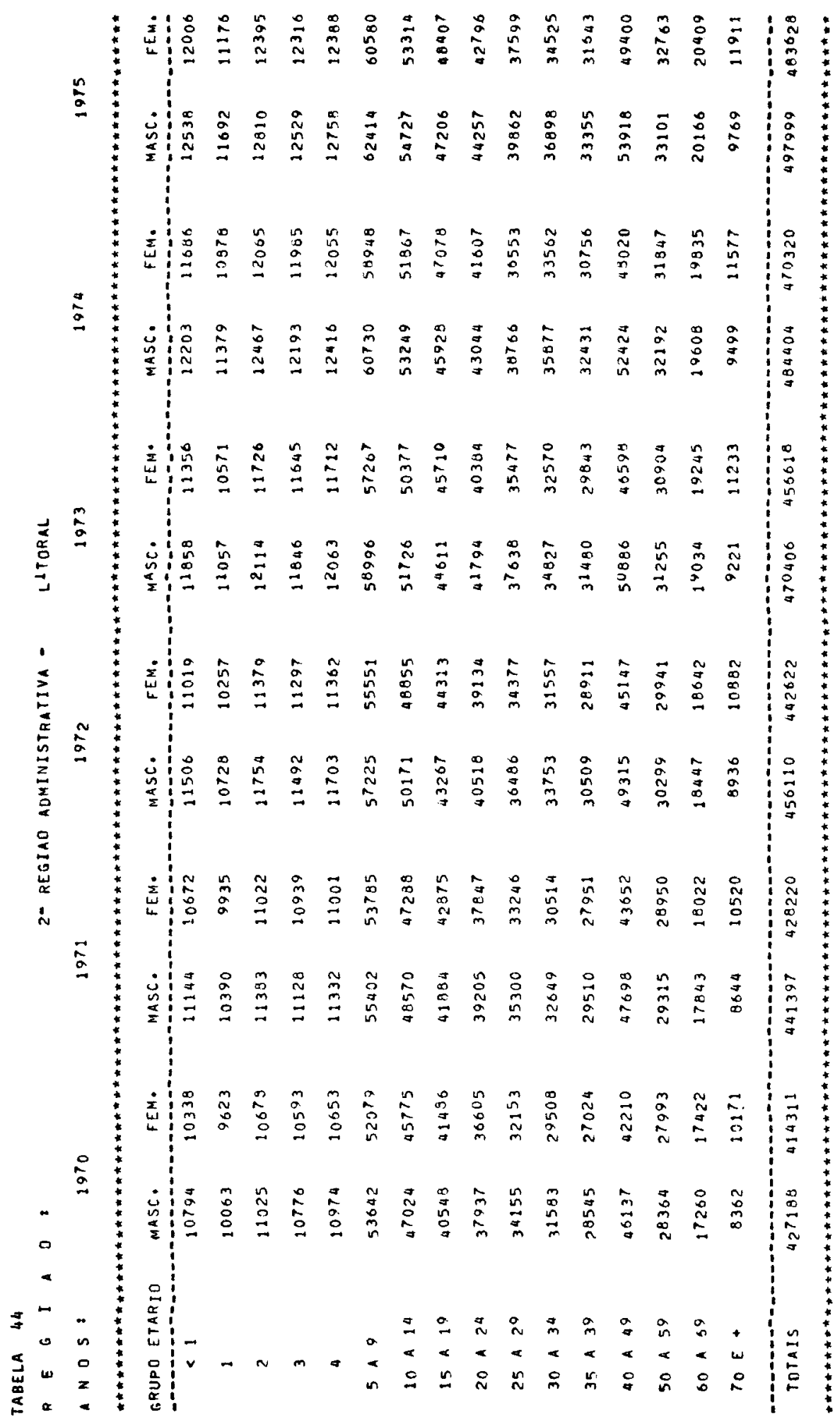




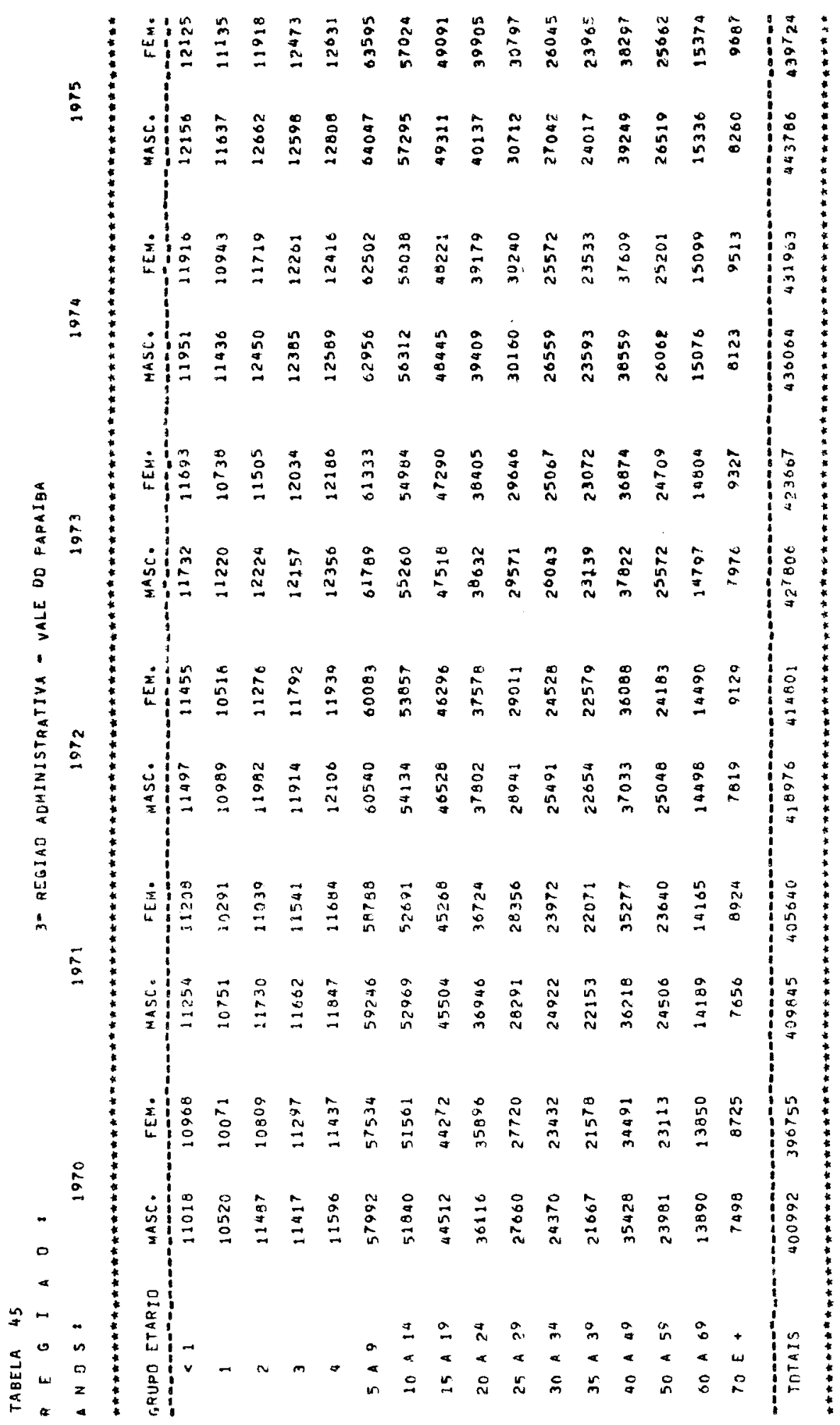




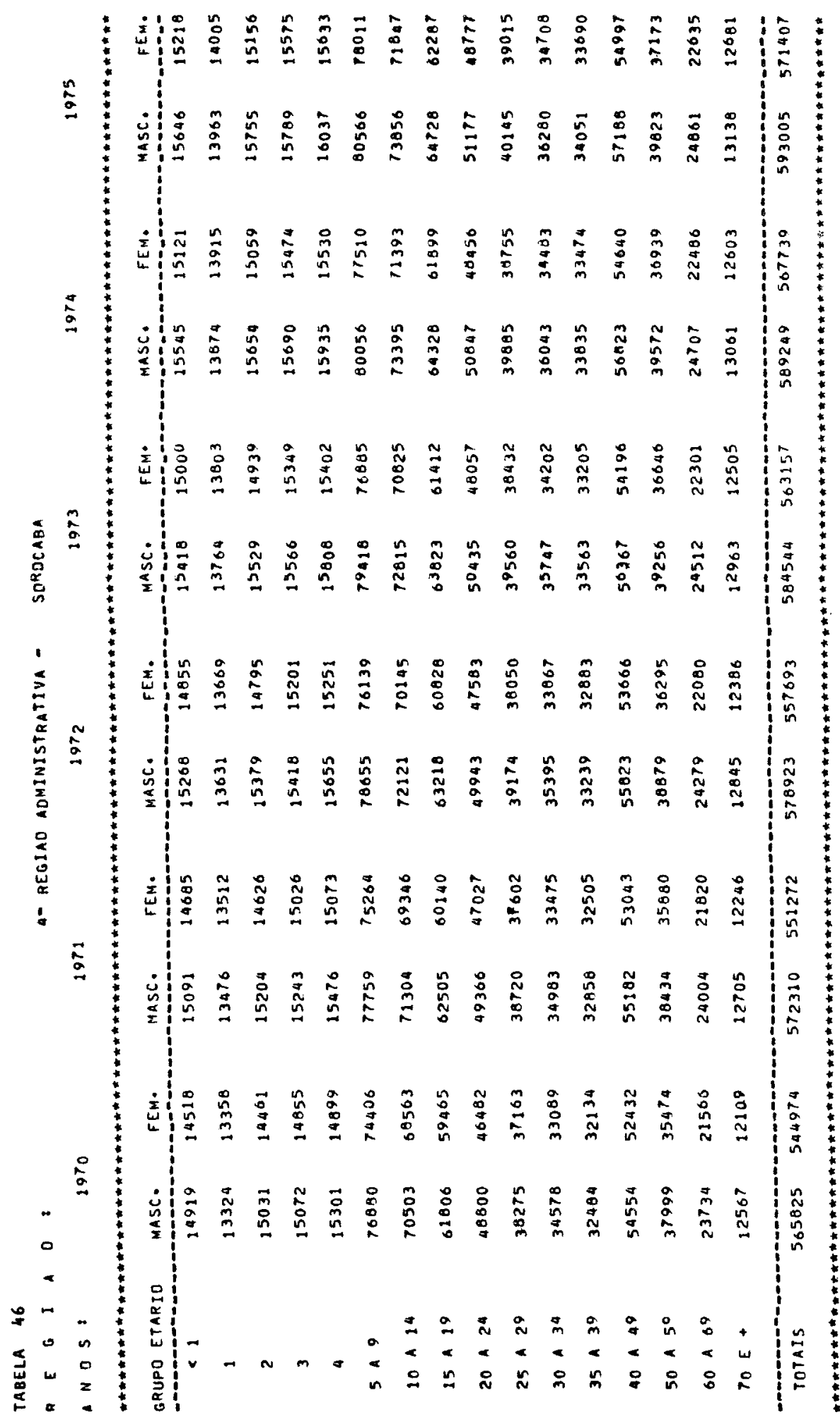




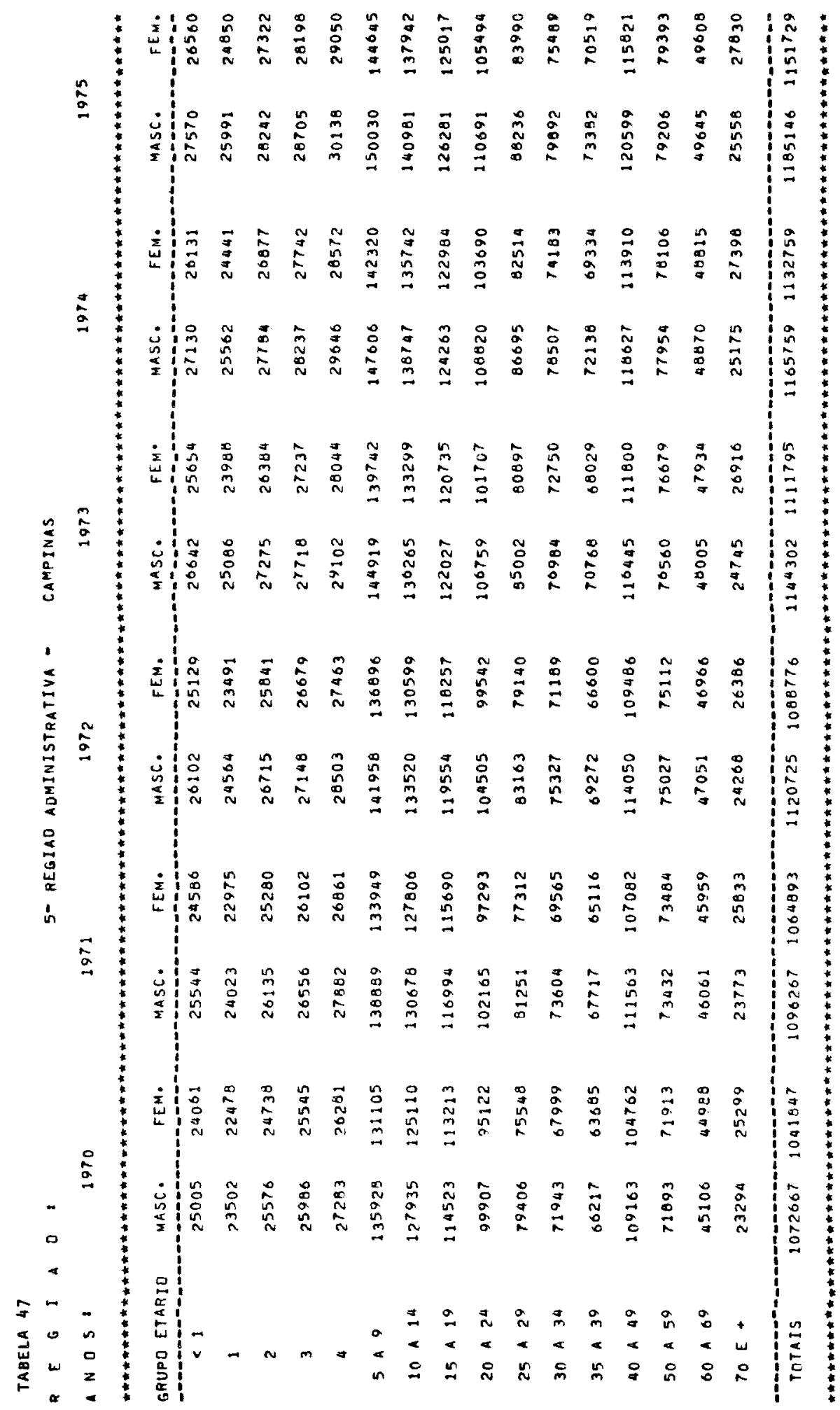




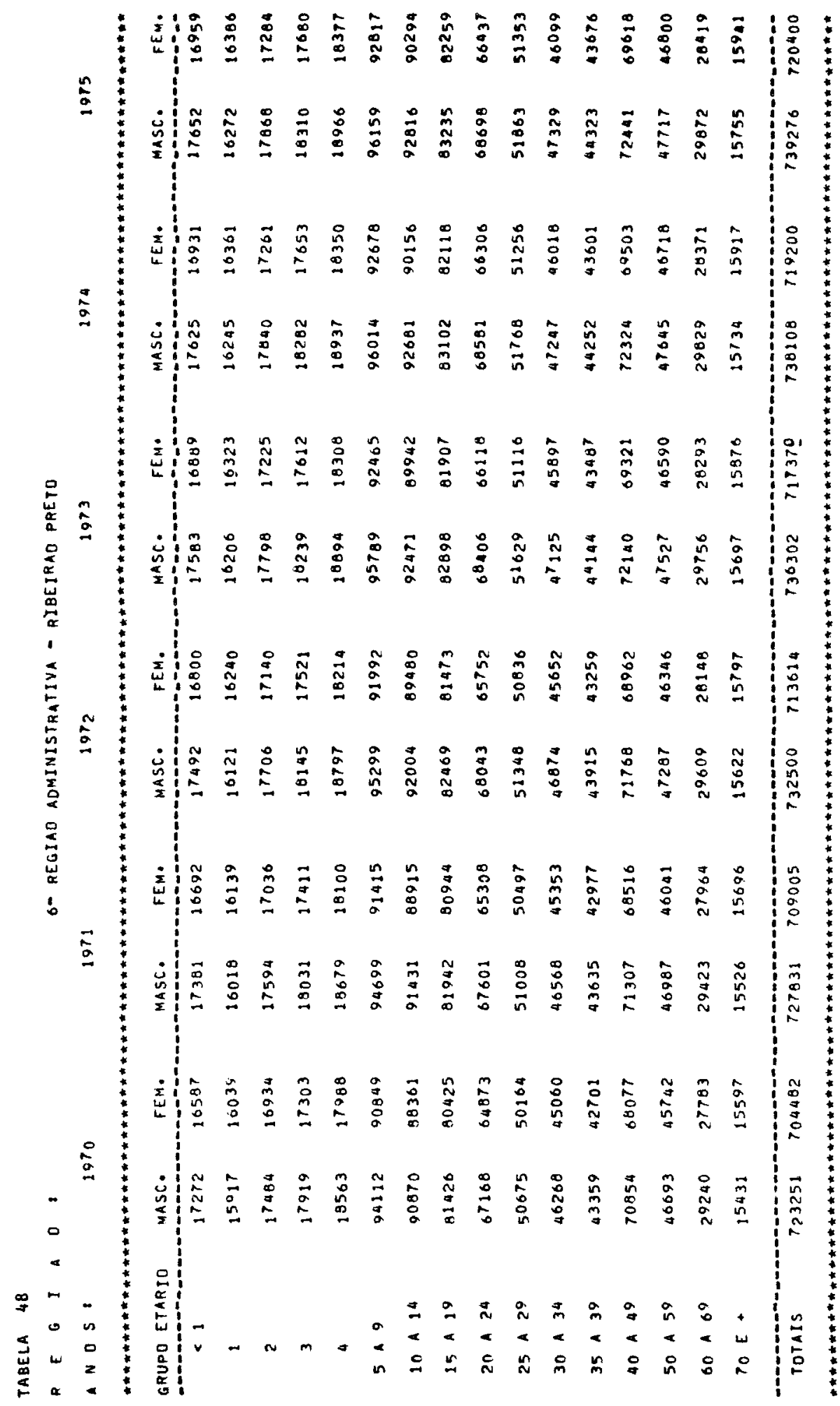




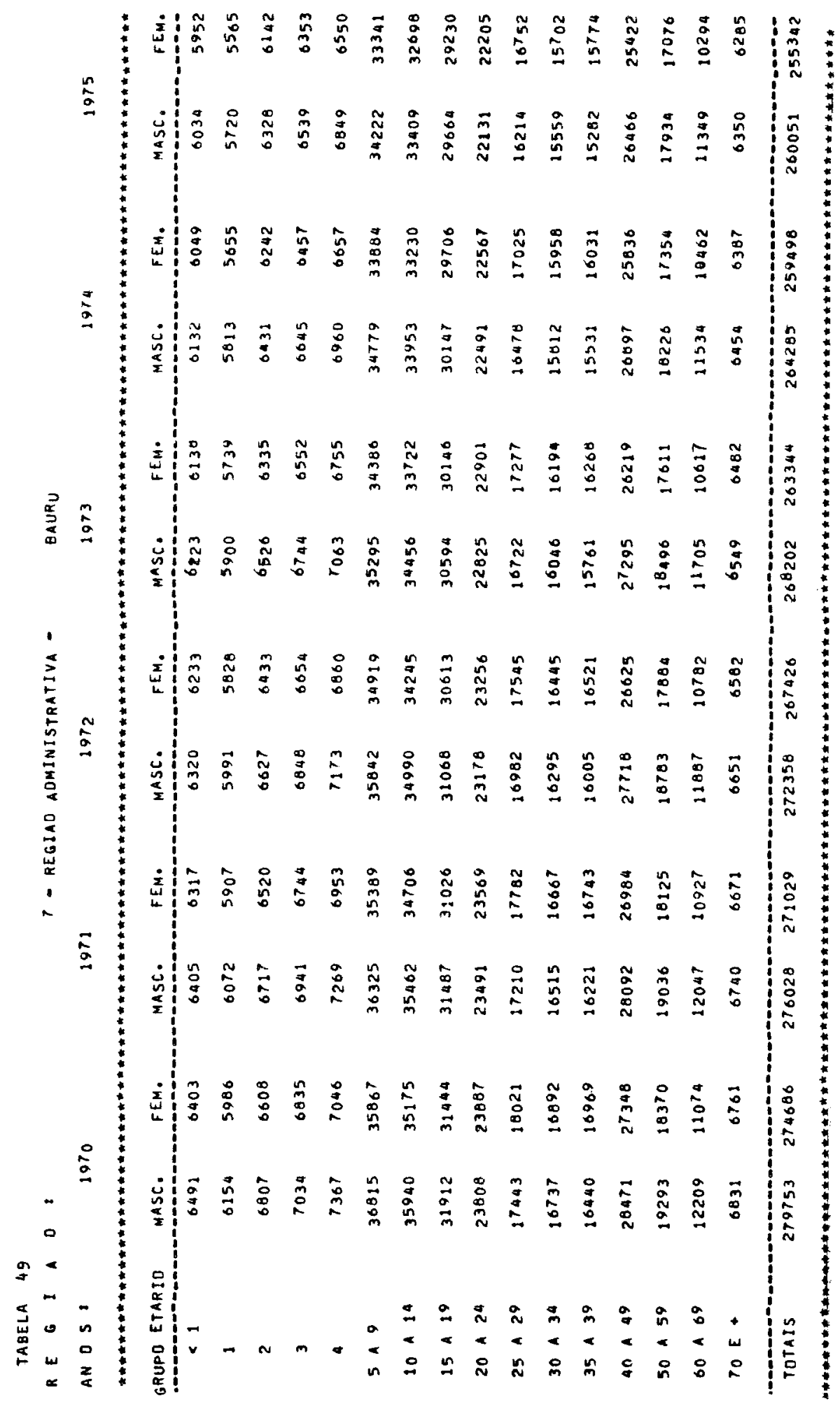




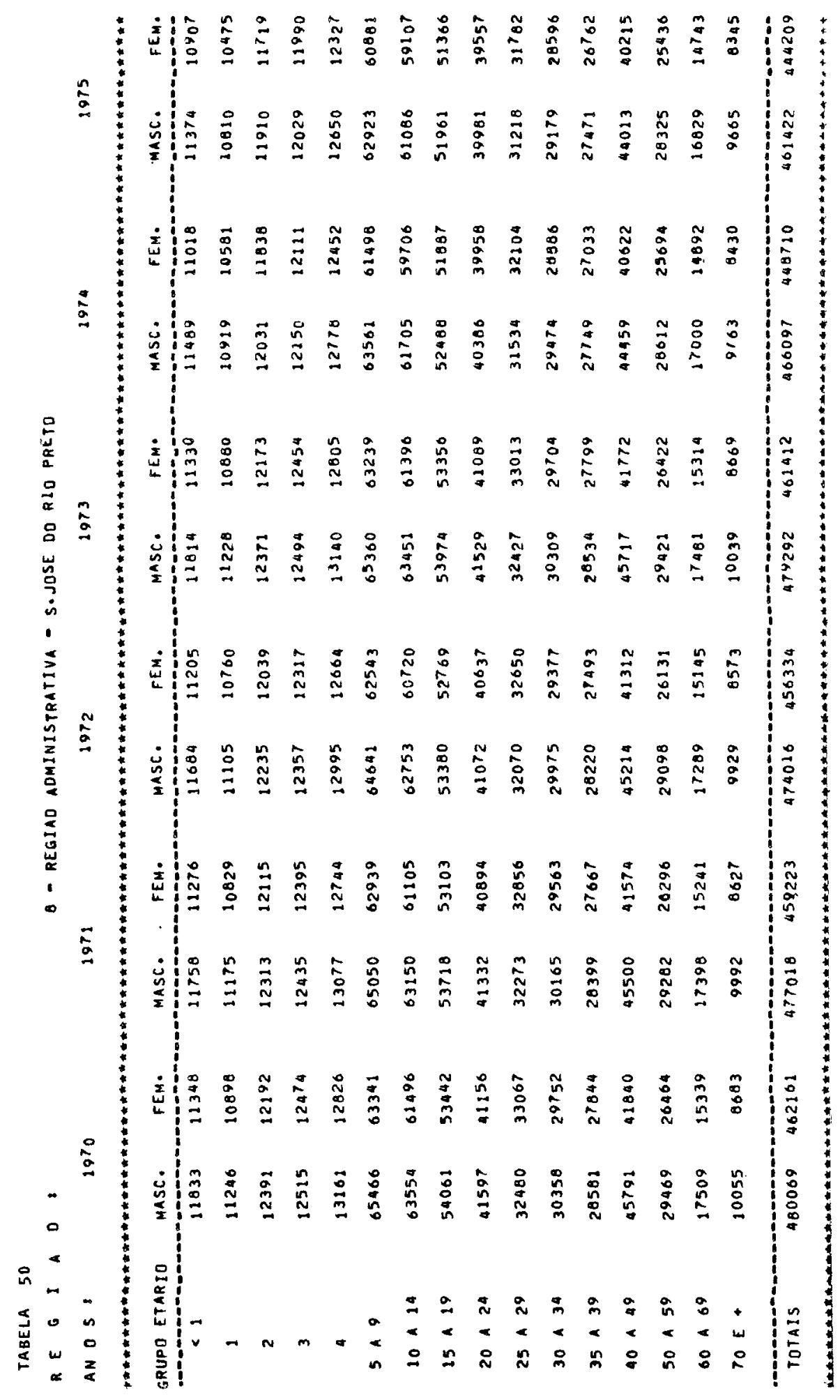




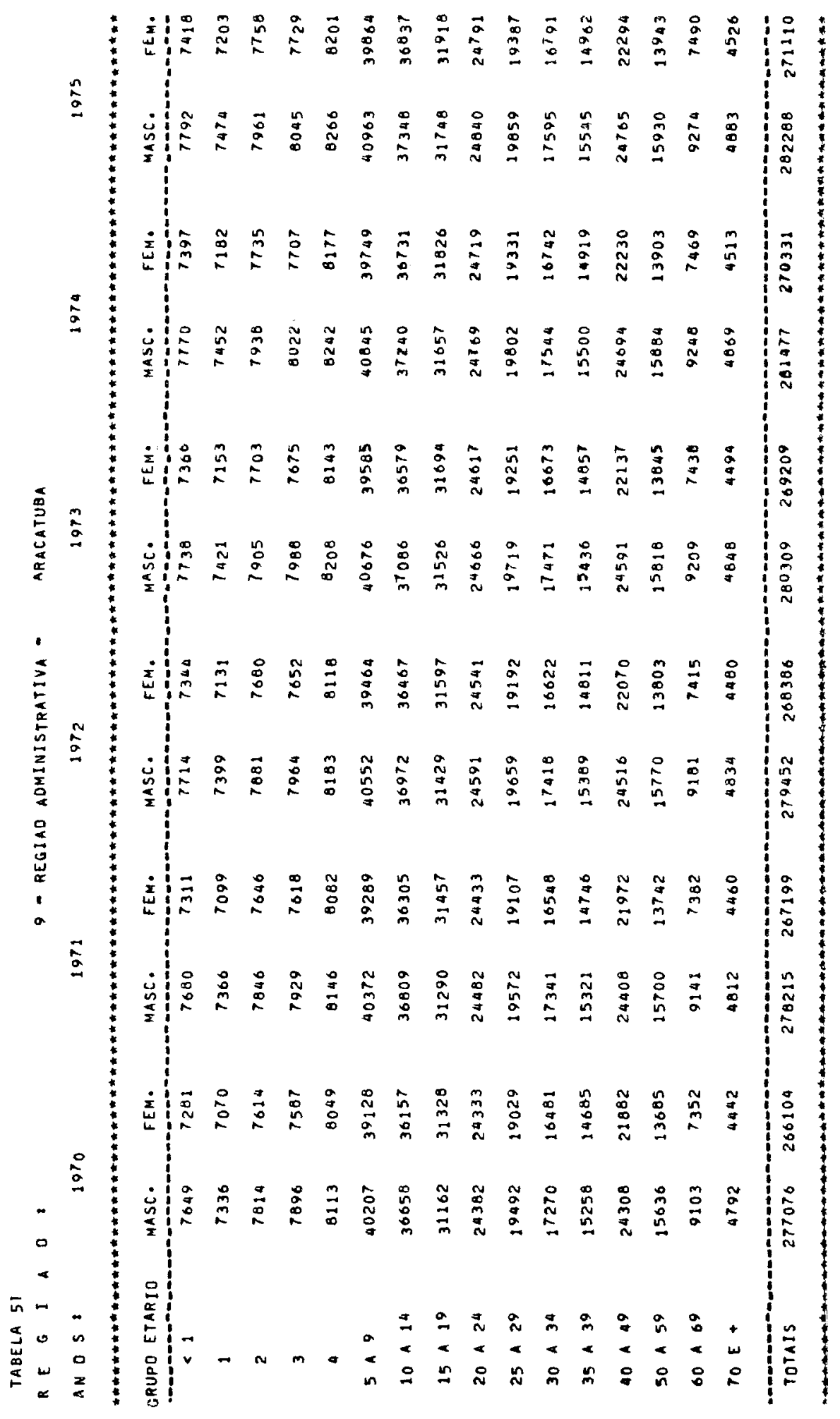




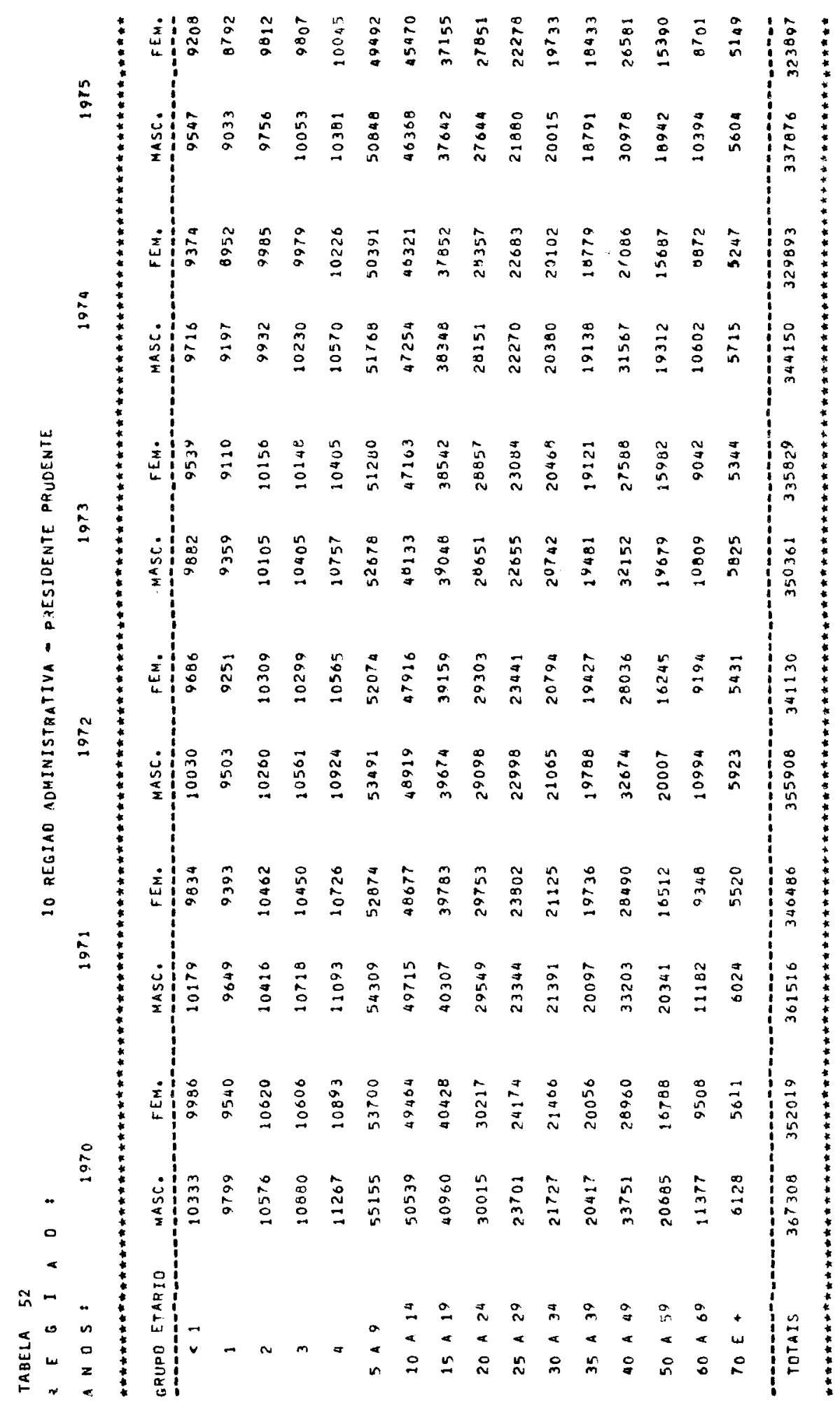




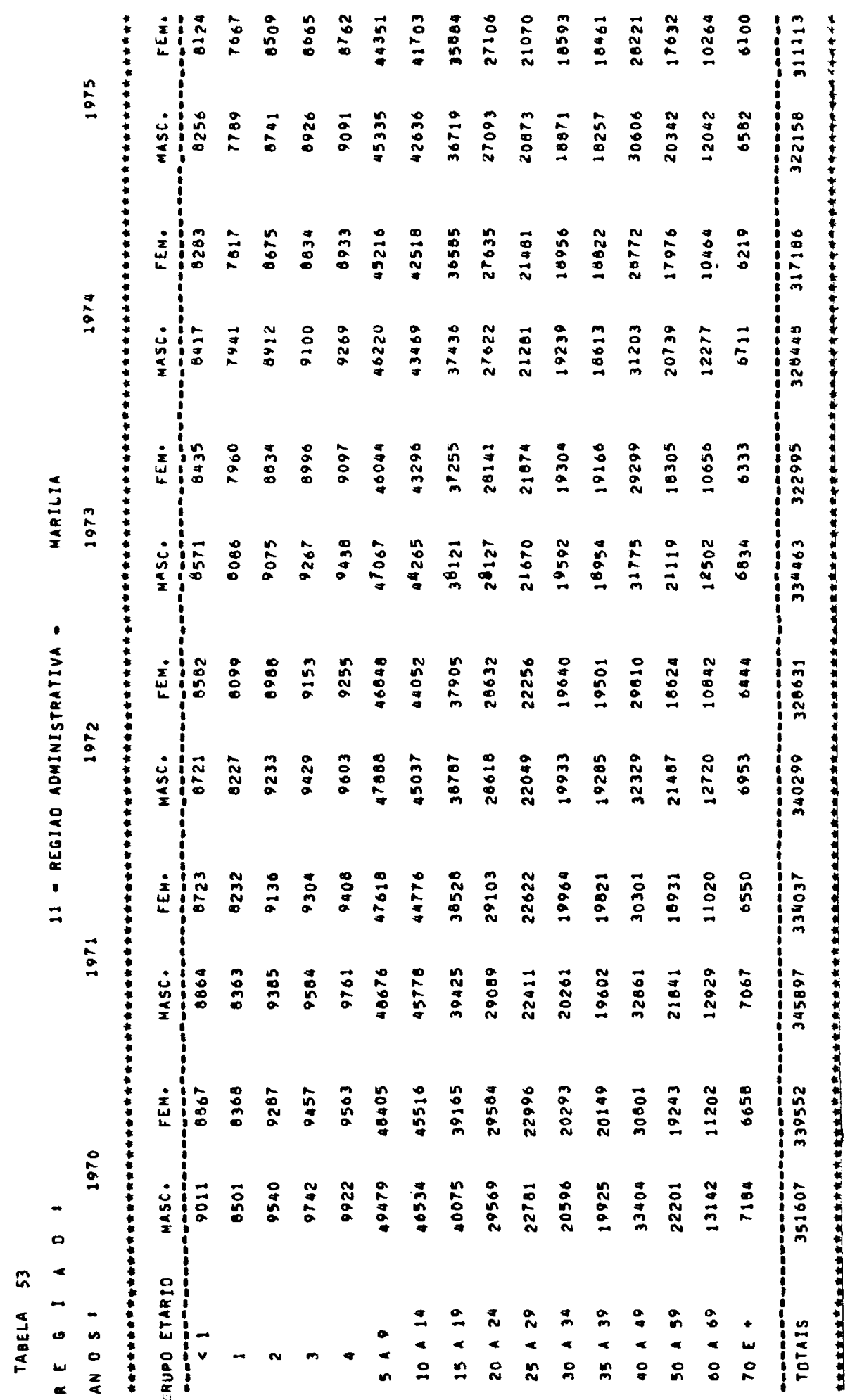

